\title{
Regenerative neurogenic response from glia requires insulin driven neuron-glia communication
}

Neale Harrison ${ }^{1,2}$, Elizabeth Connolly ${ }^{1 *}$, Alicia Gascón Gubieda ${ }^{1,3}$, Zidan Yang ${ }^{1,4}$, Benjamin Altenhein ${ }^{5}$, Maria Losada-Perez ${ }^{6}$, Marta Moreira ${ }^{1}$ and Alicia Hidalgo ${ }^{1 \#}$

* These authors contributed equally

1, NeuroDevelopment Group, School of Biosciences, University of Birmingham, UK. 2, Current address: Tomlinson Lab, School of Biosciences, University of Birmingham, UK. 3, Current address: Institute for Cell and Molecular Biosciences, Newcastle University, Newcastle upon Tyne NE2 4HH, UK. 4, Current address: Max Planck Florida Institute for Neuroscience,1 Max Planck Way, Jupiter, Florida 33458, USA; 5, Institute of Zoology, University of Cologne, Germany; 6, Instituto Cajal, Consejo Superior de Investigaciones Cientificas (CSIC), Madrid, Spain.

\# Author for correspondence:

Professor Alicia Hidalgo ph 0044 (0)1214145416 a.hidalgo@bham.ac.uk

Word count: 7,900 in main text

Figures: 10 main figures, plus 5 supplementary figures and one supplementary table.

Keywords: Drosophila, CNS, neuron, glia, neural stem cell, regeneration, kon-tiki, NG2, NG2-glia, OPC, insulin, ia-2, prospero, Notch, Deadpan, Repo, glial regenerative response, neurogenesis, damage, injury, spinal cord, brain, ventral nerve cord, larva. 


\section{ABSTRACT}

Some animals can regenerate their central nervous system (CNS) after injury by inducing de novo neurogenesis: discovering the underlying mechanisms would help promote regeneration in the damaged human CNS. Glial cells could be the source of regenerative neurogenesis, but this is debated. The glia transmembrane protein Neuron-Glia antigen-2 (NG2) may have a key role in sensing injury-induced neuronal signals, however these have not been identified. Here, we used Drosophila genetics to search for functional neuronal partners of the NG2 homologue kon-tiki (kon), and identified Islet Antigen-2 (la-2), required in neurons for insulin secretion. Alterations in la-2 function induced neural stem cell fate, injury increased ia-2 expression and induced ectopic neural stem cells. Using genetic epistasis analysis and lineage tracing, we demonstrate that la-2 functions with Kon to regulate Drosophila insulin-like peptide 6 (Dilp-6) which in turn generates both more glial cells and neural stem cells from glia. Ectopic neural stem cells can divide, and limited de novo neurogenesis could be traced back to glial cells. Altogether, la-2 and Dilp-6 drive a neuron-glia relay that restores glia, and reprograms glia into neural stem cells for CNS regeneration.

\section{INTRODUCTION}

The central nervous system (CNS) can regenerate after injury in some animals, and this involves de novo neurogenesis (Tanaka and Ferretti 2009). Newly formed neurons integrate into functional neural circuits, enabling the recovery of function and behavior, which is how CNS regeneration is measured (Tanaka and Ferretti 2009). The human CNS does not regenerate after injury. However, in principle it could, as we continue to produce new neurons throughout life, that integrate into functional circuits (Tanaka and Ferretti 2009; Gage 2019). Through understanding the molecular mechanisms underlying natural regenerative neurogenesis in animals, we might be able to provoke de novo neurogenesis in the human CNS, to promote regeneration after damage or neurodegenerative diseases. Regenerative neurogenesis across animals may reflect an ancestral, evolutionarily conserved genetic mechanism, which manifests itself to various degrees in 
regenerating and non-regenerating animals (Tanaka and Ferretti 2009). Accordingly, it may be possible to discover molecular mechanisms of injury-induced neurogenesis in the fruit-fly Drosophila, which is a powerful genetic model organism.

Regenerative neurogenesis could occur through activation of quiescent neural stem cells, dedifferentiation of neurons or glia, or direct conversion of glia to neurons (Tanaka and Ferretti 2009; Falk and Gotz 2017). Across many regenerating animals, new neurons originate mostly from glial cells (Tanaka and Ferretti 2009; Falk and Gotz 2017). In the mammalian CNS, radial glial cells behave like neural stem cells to produce neurons during development. Remarkably, whereas NG2-glia (also known as oligodendrocyte progenitor cells, OPCs) produce only glia (oligodendrocytes and astrocytes) in development, they can also produce neurons in the adult and upon injury (Dimou and Gotz 2014; Falk and Gotz 2017; Valny et al. 2017; Du et al. 2020) - although this remains controversial. Discovering the molecular mechanisms of a neurogenic response of glia is of paramount urgency.

NG2-glia are progenitor cells in the adult human brain, constituting $5-10 \%$ of cells in the total CNS, and remain proliferative throughout life (Dimou and Gotz 2014). In development, NG2-glia are progenitors of astrocytes, OPCs and oligodendrocytes, but postnatally and upon injury they can also produce neurons (Dimou and Gotz 2014; Torper et al. 2015; Falk and Gotz 2017; Valny et al. 2017; Du et al. 2020). They can also be directly reprogrammed into neurons that integrate into functional circuits (Torper et al. 2015; Pereira et al. 2017). The diversity and functions of NG2-glia are not yet fully understood, but they are particularly close to neurons: they receive and respond to action potentials integrating them into calcium signals, monitor and modulate the state of neural circuits by regulating channels, secrete chondroitin sulfate proteoglycan perineural nets, and they also induce their own proliferation to generate more NG2-glia, astrocytes that sustain neuronal physiology, and oligodendrocytes that enwrap axons (Dimou and Gotz 2014; Sakry and Trotter 2016; Sun et al. 2016; Du et al. 2020). NG-2 glia have key roles in brain plasticity, homeostasis and repair in close 
interaction with neurons (Dimou and Gotz 2014; Sakry and Trotter 2016; Du et al. 2020), but to what extent this depends on the NG2 gene and protein, is not known.

NG2 (also known as chondroitin sulfate proteoglycan 4, CSPG4) is expressed by NG2-glia and pericytes, but not by oligodendrocytes, neurons, or astrocytes (Cahoy et al 2008). NG2 is a transmembrane protein that can be cleaved upon neuronal stimulation to release a large secreted extracellular domain and an intracellular domain (Sakry et al. 2014; Sakry and Trotter 2016). The intracellular domain (ICD, NG2 $\left.2^{I C D}\right)$ is mostly cytoplasmic, and it induces protein translation and cell cycle progression (Nayak et al. 2018). NG2 ${ }^{I C D}$ lacks a DNA binding domain and therefore does not function as a transcription factor, but it has a nuclear WW4 domain and nuclear localization signals, and can regulate gene expression (Sakry et al. 2015; Sakry and Trotter 2016; Nayak et al. 2018). It is thought that NG2 functions as a receptor, triggering nuclear signalling in response to ligands/partners (Sakry et al. 2014; Sakry and Trotter 2016). NG2 protein is abundant in proliferating NG2-glia and glioma (Sakry et al. 2015; Sakry and Trotter 2016; Nayak et al. 2018), and it is required for OPC proliferation and migration in development and in response to injury (Kucharova and Stallcup 2010; Kucharova et al. 2011; Biname et al. 2013). Given the close relationship of NG2-glia with neurons, it is anticipated that key partners of NG2 are produced from neurons, but these remain largely unknown.

The fruit-fly Drosophila is particularly powerful for discovering novel molecular mechanisms. The Drosophila NG2 homologue is called kon-tiki (kon) or perdido (Estrada et al. 2007; Schnorrer et al. 2007; Perez-Moreno et al. 2017). Kon functions in glia, promotes glial proliferation and glial cell fate determination in development and upon injury, and promotes glial regeneration and CNS injury repair (Losada-Perez et al. 2016). Kon works in concert with the receptor Notch and the transcription factor Prospero (Pros) to drive the glial regenerative response to CNS injury (Kato et al. 2011; LosadaPerez et al. 2016). It is normally found in low levels in the larval CNS, but injury induces a Notchdependent increase in kon expression in glia (Losada-Perez et al. 2016). Together, Notch signaling and Kon induce glial proliferation; Kon also initiates neuropile glial differentiation and pros 
expression, and Pros maintains glial cell differentiation (Griffiths and Hidalgo 2004; Kato et al. 2011;

Losada-Perez et al. 2016). This glial regenerative response to injury is homeostatic and time-limited, as two negative feedback loops halt it: Kon represses Notch, and Pros represses kon expression, preventing further cell division (Kato et al. 2011; Losada-Perez et al. 2016). The relationship between these genes is also conserved in the mouse, where the homologue of pros, Prox 1 , is expressed together with Notch1 in NG2-glia, and following cell division, it represses NG2-glia proliferation and promotes oligodendrocyte differentiation (Kato et al. 2015). Together, Notch, Kon and Pros form a homeostatic gene network that sustains neuropile glial integrity throughout life and drives glial regeneration upon injury (Hidalgo and Logan 2017; Kato et al. 2018). As Kon is up-regulated upon injury and provokes glial proliferation and differentiation, it is the key driver of the glial regenerative response to CNS injury.

A critical missing link to understand CNS regeneration was the identification of neuronal partners of glial NG2/Kon that could induce regenerative neurogenesis. We had observed that injury to the Drosophila larval CNS also resulted in spontaneous, yet incomplete, repair of the axonal neuropile (Kato et al. 2011). This strongly suggested that injury might also induce neuronal events, such as axonal regrowth, or generation of new neurons. Thus, we asked whether Kon may interact with neuronal factors that could contribute to regenerative neurogenesis after injury. Here, we report that relay of insulin signalling involving neuronal la-2 and glial Kon, drives in vivo reprogramming of neuropile glia into neural stem cells.

\section{RESULTS}

\section{la-2 is a functional partner of Kon produced in neurons}

To search for functional neuronal partners of Kon, we carried out genetic screens that aimed to identify genes expressed in neurons that had non-autonomous effects on glia. We exploited the fact that over-expression of kon elongates the larval ventral nerve cord (VNC) (Losada-Perez et al. 2016), and tested whether RNAi knock-down of candidate genes in neurons or glia could rescue this 
phenotype (Figure 1 - Figure Supplements 1 and 2). To validate the approach, we first tested genes predicted or known to interact with kon and/or NG2 (Schnorrer et al. 2007; Perez-Moreno et al. 2017). Indeed, knock-down of known interactors, such as integrins (Perez-Moreno et al. 2017), factors involved in Notch signaling (e.g. Mtm, Akap200), secretases (i.e. kuz, kuz-l) that cleave both Notch and NG2/Kon (Sakry and Trotter 2016), and phosphatases Prl1 and Ptp99A (Song et al. 2012), all rescued the phenotype, validating the approach (Figure 1 - Figure Supplements 1 and 2). We tested knock-down of other genes encoding phosphatases and transmembrane proteins expressed in neurons. Knocking-down phosphatases ptp99A, ptp69D and ptp4E from neurons rescued the phenotype, but most prominent was knock-down of phosphatase lar, a negative regulator of insulin signalling (Figure 1 - Figure Supplement 2A-D). Notably, knock-down of other insulin related factors including Akt and ia-2, also caused some rescue (Figure 1 - Figure Supplement 2A-D). However, multiple genes can affect VNC length, and these rescue phenotypes may not necessarily reflect specific gene interactions. Thus, we next asked whether altering kon function affected the expression of a group of genes selected from the above screens. Kon can influence gene expression, as kon mutations cause loss of glial gene expression (Losada-Perez et al. 2016). Using quantitative real-time reverse transcription PCR (qRT-PCR) on dissected larval CNSs, we found that kon knock-down in neurons (with kon ${ }^{c 452}$, elavGAL4>UAS-konRNAi) or glia (with $k^{c 452}{ }^{c 42}$, repoGAL4>UAS-konRNAi) had no effect on the expression of most phosphatases, including lar, or other tested genes, but by contrast, resulted in an approximately 3-fold increase in ia-2 mRNA levels (Figure 1 - Figure Supplement 3A). Conversely, over-expression of full-length kon in either neurons or glia down-regulated ia-2 mRNA levels by $25 \%$ (Figure 1 - Figure Supplement $3 \mathrm{~B}$ ). We validated these results by increasing the repeats of the most promising subset of genes (Figure 1 - Figure Supplement $3 C, D$ ), and this confirmed the strongest effect of kon loss and gain of function on ia-2 (Figure 1A). Accordingly, Kon function in glia prevents ia-2 expression. Next, we asked whether knock-down or over-expression of ia-2 in neurons (with elavGAL4) had any effect on kon mRNA levels, but none did (Figure 1B). However, overexpression of ia-2 in glia (with repoGAL4>ia-2[GS11438]) decreased kon mRNA levels (Figure 1B). As 
Kon functions in glia (Losada-Perez et al. 2016), these data indicated that kon and ia-2 restrict each other's expression to glia or neurons, respectively, and/or that la-2 is restricted to neurons. Either way, these data showed that $i a-2$ and kon interact genetically.

Our genetic and qRT-PCR based screens had identified genetic interactions between kon and lar, Akt and ia-2. LAR is involved in neuronal axon guidance, and is responsible for dephosphorylating, and thus inactivating, insulin receptor signaling (Mooney et al. 1997; Wills et al. 1999). Akt is a key effector of insulin receptor signalling downstream (van der Heide et al. 2006). la-2 is a highly evolutionarily conserved phosphatase-dead transmembrane protein phosphatase required in dense core vesicles for the secretion of insulin, insulin-related factor-1 (IGF-1) and neurotransmitters; it also has synaptic functions and influences behaviour and learning (Cai et al. 2001; Harashima et al. 2005; Hu et al. 2005; Henquin et al. 2008; Cai et al. 2009; Nishimura et al. 2010; Cai et al. 2011; Carmona et al. 2014). Rather unexpectedly, our findings suggested that Kon is involved in insulin signalling.

To ask whether and how la-2 might relate to the Kon-Notch-Pros glial regenerative gene network, we tested whether loss or gain of function for Notch or pros might affect ia-2 expression. With qRT-PCR on dissected larval CNSs, we found that Notch $^{\text {ts }}$ mutants had an almost two-fold increase in ia-2 expression, whereas Notch ${ }^{I C D}$ over-expression in glia $\left(\right.$ repoGAL4>Notch $\left.{ }^{I C D}\right)$ caused no significant effect (Figure 1C). Like Kon, Notch also functions in glia (Griffiths and Hidalgo 2004; Kato et al. 2011; Losada-Perez et al. 2016), thus the genetic inference is that ia-2 expression is prevented by Notch in glia. la-2 mRNA levels also increased (albeit not significantly) in pros mutant larvae, but mostly when pros was over-expressed in glia (Figure 1D). The loss of function phenotype could be indirect, as in glial cells Pros and Notch depend on each other (Kato et al. 2011), loss of pros causes the down-regulation of Notch, which would increase ia-2 expression. Instead, the stronger effect of pros gain of function on ia-2 indicated that Pros could directly regulate ia-2 expression. Importantly, Pros is a transcription factor found in glia, type I and II neuroblasts, ganglion mother cells and some neurons (Bayraktar et al. 2010). Thus, Pros could regulate ia-2 expression in any of these cell types. 
Most importantly, these data meant that ia-2 participates in the kon, Notch, pros gene network that drives the regenerative response to CNS injury.

The above data suggested that ia-2 expression is normally excluded from glia. To test what cells express $i a-2$, we knocked-down ia-2 with RNAi in either neurons or glia and measured ia-2 mRNA levels with qRT-PCR in dissected larval CNSs. ia-2-RNAi knock-down in glia (repoGAL4>UASia$2 R N A i^{\text {TRIPHMS00536 }}$ ) had no effect, however knock-down in neurons (elavGAL4>UASia-2RNAi $i^{\text {TRIPHMSO0536 }}$ ) down-regulated ia-2 transcripts to about $20 \%$ of wild-type levels (Figure 1E). A second UAS-ia-2 RNAi line (line UAS-ia-2RNAi $i^{K 108555-V I E-260 B}$ ) had a milder effect, but still reduced $i a-2$ expression by $25 \%$ (Figure 1E). These data meant that ia-2 is expressed in neurons. To visualize ia-2 expression in vivo, we used a transgenic protein fusion of la-2 to yellow fluorescent protein (YFP), la-2YFP ${ }^{\text {CPTI100013 }}$ (Lowe et al. 2014; Lye et al. 2014), from now on called la-2YFP. la-2YFP+ cells did not have the glial marker anti-Repo, nor anti-Deadpan (Dpn), which is the general neuroblast marker and also labels transit amplifying ganglion mother cells in type II neuroblast lineages (Boone and Doe 2008), but all la-2YFP+ cells were Elav+ (Figure 1F,G,H). This demonstrated that ia-2 is expressed exclusively in neurons.

Altogether, these data showed that la-2 and Kon function within the regenerative gene network, and are restricted to neurons and glia, respectively (Figure 1I).

\section{Alterations in la-2 levels induce ectopic neural stem cells}

Next, we carried out a functional analysis of $i a-2$ in the CNS. As kon knock-down increased ia-2 mRNA levels, we sought to verify this using la-2YFP. la-2YFP+ appeared undistinguishable from wild-type when kon was knocked-down in glia ( kon $^{c 452} /$ ia-2YFP; repoGAL4>kon-RNAi), but as la-2YFP is normally in all neurons, a potential effect could have been missed. Thus, we focused on the midline, where a limited number of dorsal la-2YFP+ neurons can be counted. Indeed, kon loss of function in glia increased the number of la-2YFP+ cells along the midline (Figure 2A,B). The ectopic ia-2YFP cells had the neuronal marker Elav and did not have the glial marker Repo (Figure 2C), meaning they were neurons. Midline cells were unaffected by kon over-expression in either neurons or glia (Figure 2A,B, 
elavGAL4>kon and repoGAL4>kon). Thus, in the absence of kon, ectopic la-2YFP+ neurons were found at the midline. Loss of kon function prevents glial differentiation (Losada-Perez et al. 2016), and could result in more la-2YFP+ neurons also in other locations, but we were unable to verify this. The increase in neurons could explain why ia-2 mRNA levels increased with kon loss of function (see Figure 1A), although the mRNA levels for ptp99A, $-69 F$ and $10 D$ (Figure 1 - Figure Supplement 3) also known to function in neurons were not increased. Either way, these data confirmed that Kon and la2 are mutually exclusive in glia and neurons, respectively.

To ask what function la-2 might have in neurons, we altered ia-2 expression and visualized the effect using standard neuronal markers. ia-2 knock-down in neurons (elavGAL4>ia$2 R N A i^{\text {TRIPHMS00536 }}$ ) had no detectable effects on Fasll or BP102 (Figure 2 - Figure Supplement 1A,B), and it did not change Eve+ neuron number either (Figure 2D,E). As Pros activates ia-2 expression (Figure 1D), we asked whether ia-2 might affect Pros. Over-expression of ia-2 in either neurons or glia had no effect on Pros+ cells (Figure 2F,G). By contrast, ia-2 knock-down in neurons (elavGAL4>ia$2 R N A i^{\text {TRIPHMSO0536 }}$ ) increased Pros+ cell number, these cells looked small (Figure $2 \mathrm{~F}, \mathrm{G}$ ) and lacked the glial marker Repo (Figure $2 \mathrm{H}$ ). Pros is normally found in ganglion mother cells and neurons, which are generally smaller than glia, suggesting that the ectopic Pros+ cells might be amongst these cell types.

To test whether ectopic Pros+ cells originated from neural stem cells, we asked whether altering ia-2 function might affect the expression of the general neuroblast marker $d p n$. Both ia-2 gain of function (elav>ia-2) and loss of function (Df(2L)ED7733/+; elav>ia-2RNAi ${ }^{\text {TRIPHMSO0536 }}$, and elavGAL4 knock-down using two different RNAi lines, UAS-ia-2RNAi $i^{\text {TRIPHMS00536 }}$ and UAS-ia-2RNA ${ }_{\text {KK108555-VIE-260B }}$ ), in neurons increased the number of abdominal VNC Dpn+ cells (Figure 2I,J). The increase in Dpn+ cell number also correlated with tumorous overgrowths in the VNC (Figure $2-$ Figure Supplement $1 C$ ), characteristic of genotypes causing neuroblast over-proliferation. The ectopic Dpn+ cells were distributed along the midline, and around the neuropile, in positions normally occupied by glial cells (Figure 2l). The ectopic Dpn+ cells were distinct from normal larval neural stem cells, which are ventro-lateral and further away from the neuropile. Furthermore, they 
were visualised $120 \mathrm{~h}$ after egg laying (AEL), after the disappearance of developmental abdominal neural stem cells. Thus, alterations in the levels of neuronal la-2 induced neural stem cell marker expression ectopically.

These data showed that interference with normal neuronal la-2 levels up-regulated ganglion mother cell and neural stem cell markers. This effect was non-autonomous, as neurons themselves seemed unaffected. As la-2 and Kon are functionally related but confined to either neurons or glia, respectively, this suggested that communication between neurons and glia was involved in inducing an ectopic neural stem cell state.

\section{Injury induces ia-2 expression and a regenerative neurogenic response}

Above data had shown that altering ia-2 levels up-regulated the neural stem cell marker Dpn (Figure 2I,J). Since CNS injury induced the up-regulation of kon expression (Losada-Perez et al. 2016), we asked whether injury might affect ia-2 expression and, consequently, induce a neurogenic response. To this end, crush injury was carried out at 74-76h after egg laying (AEL) in early third-instar larval VNCs labelled with the endoplasmic reticulum GFP marker G9 (Figure 3A,D), using a previously established protocol (Losada-Perez et al. 2016). qRT-PCR in injured VNCs revealed approximately a 2fold increase in ia-2 mRNA levels at 5-7h post-injury, which recovered homeostatically by $24 \mathrm{~h}$ postinjury (Figure 3D). This paralleled the effect of injury on kon expression (Losada-Perez et al. 2016). Thus, CNS injury caused an increase in ia-2 expression.

Since increased ia-2 levels induced ectopic Dpn+ cells (Figure 2I,J), and ia-2 was up-regulated in injury, we asked whether injury induced neural stem cells. We focused in the abdominal VNC only, which has 3 neuroblasts per hemi-segment in ventro-lateral positions, in early third instar larvae. Crush injury in the abdominal VNC at 74-76h AEL resulted in ectopic Dpn+ cells by 5-7h later (Figure $3 A, F, G, H)$. These were more numerous than the normal developmental abdominal larval neuroblasts, and included cells located in dorsal positions, which are not normally occupied by them (Figure 3F,G; see (Sousa-Nunes et al. 2011; Froldi et al. 2015). The numerous Dpn+ cells could correspond to 
injury-induced divisions of neuroblasts normally found during larval development. To test whether injury might induce ectopic neural stem cells distinct from developmental neuroblasts, we next carried out crush injury at three later time points: (1) at 96h AEL and analysed the VNCs $6 \mathrm{~h}$ postinjury (PI, 102h AEL), when in control VNCs, abdominal hemi-segments have 0 or $1 \mathrm{Dpn}+$ cells remaning (Figure 3B,I,J,K); (2) At 105h and analysed 24h PI (129h AEL), when in controls there are no ventro-lateral neuroblasts, only Dpn+ cells along the midline (Figure 3L); and (3) at 117h AEL and analysed the VNCs 12h PI (129h AEL), taking advantage of the delayed pupariation of injured larvae (Figure $3 \mathrm{M}, \mathrm{N}, \mathrm{O}$ ). At $129 \mathrm{~h} \mathrm{AEL}$ there were no remaining abdominal ventro-lateral neural stem cells in intact controls, only some Dpn+ cells along the midline (Figure $3 \mathrm{~N}$ ). Injury induced at these three later time points, also caused ectopic Dpn+ cells compared to controls (Figure $3 \mathrm{~K}, \mathrm{~L}, \mathrm{O}$ ), and most, if not all, ectopic Dpn+ cells lacked la-2YFP (Figure 3F,G,IJ,M,N). Importantly, most ectopic Dpn+ cells surrounded the neuropile, and some were dorsal, in positions never occupied by developmental neural stem cells (Figure $3 \mathrm{~J}, \mathrm{~N}$ ). In the samples with ectopic Dpn+ cells, these were found surrounding the lesions (Figure 3I-N,P). These data showed that injury induces ectopic neural stem cells, and these are distinct from developmental neuroblasts. Since ia-2 levels increased upon injury, and $i a-2$ gain of function induced neural stem cells, this suggested that ia-2 was responsible for the increase in Dpn+ cells caused by injury.

\section{Dilp-6 depends on neuronal la-2 and glial Kon}

The above data raised the question of how la-2 might induce ectopic neural stem cells. la- 2 is highly evolutionarily conserved and it functions in dense core vesicles to release insulin and neurotransmitters (Harashima et al. 2005; Kim et al. 2008; Nishimura et al. 2010; Cai et al. 2011). There are eight Drosophila insulin-like-peptides (Dilps) and la-2 affects only Dilp-6 (Kim et al. 2008). dilp-6 is expressed in cortex and blood brain barrier CNS glia, and activates neural stem cell proliferation following a period of quiescence in normal larval development(Sousa-Nunes et al. 2011) 
(Chell and Brand 2010; Sousa-Nunes et al. 2011). Thus, we asked whether the increase in Dpn+ cells in ia-2 loss and gain function observed above involved dilp-6.

We first visualized dilp-6 expressing cells in wandering larvae using dilp6-GAL4 (Chell and Brand 2010; Sousa-Nunes et al. 2011) to drive expression of the nuclear reporter Histone-YFP (HisYFP). Most dilp-6>his-YFP+ cells were also Repo+, but they did not surround the neuropile and lacked the neuropile glial marker Pros (Figure 4A,B). Therefore, most dilp-6 expressing cells in the abdominal larval VNC were cortex and surface glia, as previously reported (Chell and Brand 2010; Sousa-Nunes et al. 2011). Some dilp6>his-YFP+ cells were Repo- Elav+, and thus were neurons (Figure 4A,B). Therefore, dilp-6 is expressed in some neurons per VNC segment, and mostly in non-neuropile glia. Kon function is required for glial cell fate (Losada-Perez et al. 2016), so we used qRT-PCR to ask whether altering Kon levels might affect dilp-6 expression. Over-expression of full-length kon midly increased dilp-6 mRNA levels (albeit not significantly), but kon knock-down in glia significantly reduced dilp-6 mRNA levels (Figure 4C,D). This effect could be indirect, as glial proliferation and differentiation are impaired with kon loss of function (Losada-Perez et al. 2016), or perhaps Kon regulates dilp-6 expression. Either way, dilp-6 expression depends on kon in glia.

Dilp-6 is a ligand for the insulin receptor $(\operatorname{InR})$, which is expressed and/or functional at least in CNS neurons and neuroblasts (Fernandez et al. 1995; Song et al. 2003; Sousa-Nunes et al. 2011; Fernandes et al. 2017). To revisit what cells might receive Dilp-6, we visualized InR expression, using available GAL4 lines to drive his-YFP, and tested co-localisation with glial and neuronal markers. At $72 \mathrm{~h} \mathrm{AEL}, \operatorname{In} R^{N P 2552}>$ his-YFP+ cells comprised some Elav+ neurons and some Repo+ glia, including dorsal neuropile glia and surface glia (Figure 4E,F). The distribution was stochastic, most likely due to the insertion of GAL4 into an intron. According to these data limited by the currently available tools, $\operatorname{InR}$ is expresed in both neurons and glia.

Altogether, these data indicated that in the third instar larva Dilp-6 is produced and secreted by la- 2 in some neurons, it is mostly produced in non-neuropile glia, and it is received by $\ln R$ in neurons and glia, including neuropile glia. 


\section{A positive neuron-glia communication loop boosts Dilp-6 production from glia}

The above data strongly suggested that a neuron-glia communication loop might serve to amplify

Dilp-6. A limiting step could be Kon, as glial dilp-6 expression depends on kon. Kon is required for glial gene expression (Losada-Perez et al. 2016), but whether this depends on the nuclear translocation of its intracellular domain, Kon ${ }^{\mathrm{ICD}}$, is unknown. In Drosophila, Kon had been reported to lack a nuclear localization signal (Schnorrer et al. 2007). In mammals, $N G 2^{\mathrm{ICD}}$ positively regulates the expression of multiple genes, including downstream targets of mTOR (Sakry et al. 2015; Nayak et al. 2018), but whether this requires nuclear $\mathrm{NG2}^{\mathrm{ICD}}$ is also unknown. Altogether, whether NG2 or Kon regulate glial gene expression through nuclear events remained unsolved. Thus, to ask whether Kon ${ }^{\text {ICD }}$ might function in the nucleus, we generated an HA-tagged form of Kon ${ }^{\mathrm{ICD}}\left(\mathrm{Kon}^{\mathrm{ICD}-\mathrm{HA}}\right)$. Glial over-expression of kon $^{I C D-H A}\left(\right.$ repoGAL4>UAS-Kon $\left.{ }^{I C D-H A}\right)$ revealed distribution of anti-HA in glial cytoplasms and colocalisation with the glial nuclear transcription factor Repo in glia cells, both in embryos and larvae (Figure 5A and Figure 5 - Figure Supplement 1)). Thus, $\mathrm{Kon}{ }^{\mathrm{ICD}}$ is distributed in the cytoplasm and nucleus, from where it could regulate gene expression.

Next, we asked whether Kon ${ }^{\mathrm{ICD}}$ is functional. Since NG2 and Kon are responsible for glial proliferation both in mammals and Drosophila (Kucharova and Stallcup 2010; Losada-Perez et al. 2016), we used glial cell number as a read-out of Kon ${ }^{I C D}$ function. First, we tested whether cleaved Kon ${ }^{I C D}$ could induce glial proliferation, like full-length Kon does (Losada-Perez et al. 2016). We overexpressed $k^{I C D}$ in glia and automatically counted glial cells labeled with the nuclear marker his-YFP, using DeadEasy software (Forero et al. 2012). Over-expression of $k \mathrm{kn}^{I C D}$ in glia increased glial cell number (UAShisYFP; repoGAL4>UASkon ${ }^{I C D}$, Figure 5B,C), meaning that Kon ${ }^{I C D}$ can induce glial proliferation. As full-length Kon also promotes glial proliferation (Losada-Perez et al. 2016), these data meant that full-length Kon is normally cleaved, releasing $\mathrm{Kon}^{\mathrm{ICD}}$ to promote glial proliferation, although we were unable to verify whether it regulates gene expression. 
In principle, Dilp-6 amplification could occur if it were first secreted from neurons by la-2, to activate InR in glia, and InR signalling in turn drove the Kon-dependent up-regulation of dilp-6 expression in glia (Figure 5F). To test whether Dilp-6 activates InR in glia, which activates Kon, we asked: (1) whether over-expression of dilp-6 could mimic the increase in glial cell number caused by $\mathrm{Kon}^{\mathrm{ICD}}$, and (2) whether this could be rescued by over-expression of a dominant negative form of the insulin receptor $\left(I n R^{D N}\right)$ in glia. We found that over-expression of dilp-6 in glial cells increased glial cell number comparably to Kon ${ }^{1 C D}$ (Figure 5B,C), and this was rescued with concomitant over-expression of $\ln R^{D N}$ in glia (Figure 5B,C). These data meant that Dilp-6 activates InR signaling in glia, and induces glial proliferation.

Dilp-6 and InR signaling reactivate quiescent developmental neural stem cells (Chell and Brand 2010; Sousa-Nunes et al. 2011), but Kon functions in glia (Losada-Perez et al. 2016). To further verify whether Kon function is restricted to glia, we asked whether Kon might also be required in neural stem cells during development at $72 \mathrm{~h} \mathrm{AEL}$, when there normally are neural stem cells in both thorax and abdomen of larvae. RNAi kon knock-down in neural stem cells with inscutable-GAL4 (insGAL4>UAS-konRNAi) did not affect the number or distribution of abdominal developmental Dpn+ cells at 72h AEL (Figure 5D,E), meaning that Kon is not required for neural stem cell development. Since glial proliferation depends on Kon (Losada-Perez et al. 2016), the fact that dilp-6 alone could reproduce the increase in cell number caused by $\operatorname{kon}^{I C D}$, and this depended on InR in glia, strongly suggested that InR signalling can activate Kon cleavage downstream in glia.

To conclude, altogether these data suggested that la-2 triggers the release of Dilp- 6 from neurons, which then is received by glial cells, where InR signaling activates Kon, which in turn induces glial proliferation, and further expression of dilp-6. Thus, a non-autonomous relay from neuronal la-2 to glial Kon promotes glial proliferation and induces a positive feedback loop that amplifies Dilp-6 production from glia (Figure 5F).

\section{la-2 and Dilp-6 can induce neural stem cells from glia}


So far, our data had shown that: alterations in la-2 levels caused either by genetic manipulation or injury induced ectopic neural stem cells; la-2 is required for the neuronal secretion of Dilp-6, which is received and amplified in cortex glia under the control of Kon; and secreted Dilp-6 is received by InR also in neuropile glia. As Dilp-6 activates quiescent developmental neural stem cells (Chell and Brand 2010; Sousa-Nunes et al. 2011), this raised the question of whether the la-2 -Kon-Dilp-6 loop not only produced more glia, but could also induce a neurogenic response from glia.

To ask whether Kon, la-2 or Dilp6 could be responsible for inducing ectopic neural stem cells from glia, we over-expressed them in glia (with repoGAL4), and analysed Dpn at 120h AEL, after the disappearance of developmental abdominal neural stem cells. Over-expression of kon did not induce ectopic Dpn+ cells (Figure 6A-D). By contrast, over-expression of $i a-2$ induced ectopic Dpn+ cells prominently along the midline but also in lateral locations surrounding the neuropile, ordinarily occupied by glia (Figure 6A-D). Over-expression of dilp-6 had a stronger effect, and there were many ectopic Dpn+ cells surrounding the neuropile (Figure 6A-D). Dpn levels in ectopic cells were generally lower than in normal neural stem cells. These data showed that both la-2 and Dilp-6 can induce $d p n$ expression, potentially in glia. However, Kon alone cannot, meaning that insulin signaling is required to induce neural stem cells. Since la-2 drives Dilp-6 production and secretion, this suggested that ultimately Dilp-6 induced ectopic neural stem cells (Figure 6E).

To further test whether la-2 up-regulated dpn ectopically via Dilp-6, we carried out epistasis analysis. Over-expression of $i a-2$ together with dilp-6 knock-down in glia (repoGAL4>UAS-ia-2, UASdilp-6RNAi), rescued the number of Dpn+ cells (Figure 6A-D), demonstrating that la-2 induces ectopic neural stem cells via Dilp-6. Furthermore, over-expression of $i a-2$ together with kon RNAi in glia (repoGAL4>UAS-ia-2, UAS-konRNAi) also rescued the Dpn+ phenotype (Figure 6A-D), confirming that dilp-6 expression depends on Kon in glia (see Figure 4C) and that Kon and Dilp-6 engage in a positive feedback loop (see Figure 5). Finally, the ectopic Dpn+ phenotype was also rescued by overexpression of dilp-6 together with $\operatorname{In} R^{D N}$ in glia (Figure 6A-D, repoGAL4>UAS-dilp6, UAS-InR ${ }^{D N}$ ), meaning that ectopic neural stem cells depend on InR signaling in glia. Together, these data showed 
that la-2 induces ectopic neural stem cells via Dilp-6 and InR signalling in glia, and that ectopic Dpn cells originated from glia (Figure 6E).

To further test whether the ectopic Dpn+ cells originated from glia, we first asked whether ectopic Dpn colocalised with the glial marker Repo, analysing larvae at $120 \mathrm{~h} \mathrm{AEL,} \mathrm{after} \mathrm{the}$ disappearance of developmental abdominal neural stem cells. Lateral ectopic Dpn+ cells observed with dilp-6 over-expression were also Repo+ (Figure 7A,B), consistent with originating from glial cells. Dpn levels were lower than in normal neural stem cells. By contrast, the ectopic midline Dpn+ cells were not Repo+. Midline glia do not normally express repo, but express wrapper (wrp). Overexpression of dilp-6 resulted in Dpn+ cells along the midline that also had Wrp (Figure 7C,D), showing that the ectopic midline Dpn+ cells were midline glia. These data showed that there are two distinct populations of ectopic Dpn+ cells: latero/dorsal Repo+ cells around the neuropile and midline Wrp+ cells, altogether indicating that Dpn is induced in neuropile glia (class known as 'astrocytes') and midline glia.

However, not all Dpn+ cells were Repo+ or Wrp+, as some did not express either of these markers (Figure 7E, white arrows; genotype: repoGAL4>his-YFP, dilp-6). This could mean that either some ectopic Dpn+ did not originate from glia, or that as glial cells reprogrammed into neural stem cells, they switched off glial gene expression. To test whether ectopic neural stem cells originated from glia, we used the cell-lineage marker G-TRACE. This GAL4-dependent tool results in the permanent labelling of GAL4/UAS-expressing cells and their lineage. Thus, as glial cells become neural stem cells, the glial repo promoter would be switched off, but G-TRACE would enable their visualisation as well as that of all their progeny cells. Cells that were originally glia but may no longer be so would be labelled in green (GFP+), and recently specified glial cells would be labelled in red (RFP+). G-TRACE expression in glia with repoGAL4 together with dilp-6 caused larval lethality and thus could not be analysed. By contrast, over-expression of both G-TRACE and ia-2 in glia (repoGAL4>G-TRACE, UAS-ia-2) revealed G-TRACE+ Dpn+ cells around the neuropile, at 120h AEL (Figure 7G,H). Most, if not all, of these cells had GFP, but also RFP (Figure 7G,H). These data 
demonstrate that ectopic Dpn+ originate from glial cells. Since RFP was also present, this suggests that glial cell fate had not been suppressed, and instead that glial cells may have been in the process of reprogramming.

Altogether, these data showed that la-2 and Dilp-6 can induce de novo formation of neural stem cells from neuropile and midline glial cells.

\section{In vivo reprogrammed glial cells can divide and generate neurons}

To ask whether ectopic neural stem cells can divide to generate neurons, we used the S-phase marker PCNA-GFP, and we over-expressed dilp-6 specifically at the third instar larva using GAL4 under the control of a heat-shock promoter. We heat-shocked larvae at $110.5 \mathrm{~h} \mathrm{AEL}$ at $37^{\circ} \mathrm{C}$ for 30 minutes, then kept them at $25^{\circ} \mathrm{C}$ for 9 hours, when they were dissected and fixed, to visualize Dpn+ and PCNA-GFP at 120h AEL. In control wandering third instar larvae, a few PCNA-GFP + cells could be observed along the midline, but not in lateral positions (Figure $8 \mathrm{~A}, \mathrm{~A}^{\prime}$ ). Over-expressed dilp-6 resulted in ectopic Dpn+ PCNA-GFP+ cells in lateral positions around the neuropile (Figure $8 B, B^{\prime}, D$ ), and along the midline (Figure $8 C, C^{\prime}, D$ ). Furthermore, Dilp-6 also resulted in PCNA-GFP+Wrp+ cells along the midline (Figure 8E-H), and in an increase in Wrp+ cells (Figure 8G). Finally, over-expression of $i a-2$ also increased cell division in midline cells visualised using the mitotic marker anti-phospho-HistoneH3, albeit not significantly (Figure 8I-L). These data demonstrate that la-2 and Dilp-6 glialreprogrammed neural stem cells can divide.

To ask whether the reprogrammed, proliferating Dpn+ cells might result in de novo neurogenesis, we first visualised cells using the pros-promoter, which drives expression in neural stem cells, ganglion mother cells, neurons and glia. Thus, we reasoned that this promoter would be less likely to be silenced through a cell-state transition. FlyBow was used as a reporter to visualise pros expressing cells. Interestingly, we could now see that the small Pros+ cells are generally neurons

(Figure 9A). Over-expression of dilp-6 with pros-GAL4 (pros ${ }^{\text {voila } G A L 4>U A S-F l y B O w, ~ U A S d i l p-6) ~ r e s u l t e d ~}$ in groups of GFP+ cells (at 120h AEL) that comprised one GFP+ cell, one GFP+Dpn+ Elav - cell, and 
one GFP+Dpn - Elav+ cell (Figure 9A,B). These data were consistent with Dilp-6 reprogrammed glia becoming neurogenic.

To further verify that neurons could be generated by Dilp- 6 from glia, we used a second lineage-tracing method. We over-expressed dilp-6 and flippase (FLP) in glia, to flip-out a stop codon placed between the actin promoter and GAL4, to swap the expression of the reporter GFP from being controlled by the glial repo promoter, to the constant actin promoter (actin>y+STOP>GAL4 UASGFP/UAS-FLP; repoGAL4/dilp-6). Thus, as reprogammed glial cells switched off the glial repo promoter and switched on neural stem cell gene expression, they and their progeny cells would still be visible with GFP. Larvae were analysed at $120 \mathrm{~h}$ AEL. In this genetic background, over-expression of dilp-6 resulted in lateral ectopic Dpn+ cells that were also GFP+ (Figure 9C,D, at 120h AEL). This showed that, like with la-2 and G-TRACE (Figure 7), ectopic Dpn+ cells induced by Dilp-6 originated from glia. Furthermore, there were groups of 2-3 GFP+ cells, some of which were Elav+, meaning they were neurons (Figure 9C,D). Importantly, GFP+ Elav+ cells were found near ectopic Dpn+ cells (Figure 9C,D). These data meant that glial-derived Dpn+ cells could produce neurons. We did not find any larger clusters, meaning that neurogenesis was most likely limited.

\section{DISCUSSION}

A critical missing link to understand how to induce CNS regeneration in non-regenerating animals such as humans, had been to identify factors that interact with NG2 to induce regenerative neurogenesis. NG2 is important because NG2-glia are abundant progenitor cells present throughout life in the adult human brain, and can respond to injury (Dimou and Gotz 2014; Torper et al. 2015; Valny et al. 2017), making them the ideal cell type to manipulate to promote regeneration. However, whether NG2-glia can give rise to neurons is highly debated, and potential mechanisms remained unknown (Dimou and Gotz 2014; Vigano and Dimou 2016; Falk and Gotz 2017; Valny et al. 2017; Du et al. 2020). Here, using Drosophila in vivo functional genetic analysis we have identified neuronal la- 
2 as a genetic interactor of the NG2 homologue Kon, and show that it can induce a neurogenic response from glial cells via insulin signalling.

We provide evidence that la-2, Kon and Dilp-6 induce a regenerative neurogenic response from glia (Figure 10). In the un-injured CNS, Kon and la-2 are restricted to glia and neurons, respectively (Figure 10A). la-2 is required for neuronal Dilp-6 secretion (Cai et al. 2001; Kim et al. 2008), Dilp-6 is produced by some neurons and mostly glia, and its production depends mostly on Kon from glia. Alterations in la-2 levels, and increased Dilp-6, cause a non-autonomous induction of ectopic neural stem cells from glia. We do not fully understand why ia-2 loss of function induced ectopic Dpn+. ia-2 loss of function would cause a decrease in Dilp-6 secretion from neurons, but not from glia, as kon mRNA levels were unaffected (Figure 1B) and dilp-6 expression depends mostly on glial kon (Figure 4C). ia-2 loss of function caused a non-autonomous increase in Pros+ cells (Figure 2FH), suggesting that perhaps cell-cell interactions involving la-2 prevent reversion to progenitor cell fate. Alternatively, as neuronal la-2 and glial Kon mutually exclude each other, perhaps loss of $i a-2$ function might result in an increase in kon function that we could not detect, and with it an increase in Dilp-6 production. As la-2 is required for Dilp-6 secretion (Cai et al. 2001; Harashima et al. 2005; Kim et al. 2008), ia-2 gain of function would increase Dilp-6 release triggering the Dilp-6 amplification loop (Figure 5). Conceivably, either way Dilp-6 increased and this induced Dpn. Upon injury, levels of kon (Losada-Perez et al. 2016) and ia-2 expression increased (Figure 10B). la-2 drives secretion of Dilp-6 from neurons, Dilp-6 is received by glia, and an amplification positive feedback loop drives the further Kon and InR dependent production of Dilp-6 from cortex glia (Figure 10B). Dilp-6 can then both promote glial proliferation to generate more glia, and induce neural stem cell marker Dpn in neuropile glia - the subset known as "Drosophila astrocytes" and midline glia (Figure 10B,C). Ectopic Dpn+ cells were induced both upon injury and genetic manipulation of la-2 and Dilp- 6 without injury, and originated from glia. Importantly, these glial-derived neural stem cells could divide, as revealed by the S-phase marker PCNA-GFP and the mitotic marker pH3; and could generate neurons, albeit to a rather limited extent. Altogether, Dilp-6 is relayed from neurons to cortex and then to neuropile 
glia. This neuron-glia communication relay could enable concerted glio- and neuro-genesis, matching interacting cell populations for regeneration (Figure 10B,D). Interestingly, Dilp-6 is also involved in non-autonomous relays between distinct CNS cell populations to activate neural stem cells and induce neuronal differentiation in development (Sousa-Nunes et al. 2011; Fernandes et al. 2017).

We have demonstrated that ectopic neural stem cells originate from glia. In principle, regenerative neurogenesis could occur via direct conversion of glia into neurons, glial dedifferentiation, or neuronal de-differentiation. Neuronal de-differentiation occurs both in mammals and in Drosophila (Froldi et al. 2015). However, in most animals, neural stem cells in the adult CNS and upon injury, are generally distinct from developmental ones, and can originate from hemocytes, but most often, glial cells (Tanaka and Ferretti 2009; Dimou and Gotz 2014; Falk and Gotz 2017; Simoes and Rhiner 2017; Du et al. 2020). In the mammalian brain, radial glia in the hippocampus respond to environmental challenge by dividing asymmetrically to produce neural progenitors that produce neurons (Shtaya et al. 2018); and astrocytes and NG2-glia can generate neurons, particularly in response to stroke, excitoxic injury, and genetic manipulations (Heinrich et al. 2014; Dimou and Gallo 2015; Peron and Berninger 2015; Du et al. 2020). Furthermore, genetic manipulation can lead to the direct conversion of NG2-glia into neurons (Torper et al. 2015; Pereira et al. 2017). Our findings that Dilp-6 and InR can induce $d p n$ expression are reminiscent of their functions in the induction of neural stem cells from quiescent progenitors in development (Chell and Brand 2010; Sousa-Nunes et al. 2011; Gil-Ranedo et al. 2019). However, the Dpn+ cells induced upon injury and after development, are distinct from the developmental neural stem cells normally induced by Dilp-6 in multiple ways. Firstly, in injuries carried out in third instar larvae, the induced neural stem cells were more numerous than normal neural stem cells. Secondly, in injuries carried out late in wandering larvae, Dpn+ cells were found after normal developmental neural stem cells have been eliminated through apoptosis (Bello et al. 2003). Thirdly, Dpn+ cells were found in dorsal ectopic locations not normally occupied by developmental neural stem cells. In all injury and genetic manipulation experiments involving over-expression of either ia-2 or dilp-6, ectopic Dpn+ cells were 
located along the midline and surrounding the neuropile, in positions normally occupied by glia. We demonstrated that ectopic Dpn+ originated from neuropile glia, including both midline glia and "Drosophila astrocytes". Firstly, ectopic Dpn+ cells did not have la-2YFP, which is expressed in all neurons. Secondly, ectopic Dpn+ cells surrounding the neuropile occupied positions of astrocytes and were Repo+, and Repo-Dpn+ along the midline were Wrp+. Thirdly, the glial origin of the ectopic Dpn+ cells was demonstrated using two cell-lineage tracing methods (G-TRACE and glial activation of the actin promoter) whereby the expression initiated from the glia repo promoter was turned permanent despite cell state transitions. Thus, la- 2 and Dilp-6 could reprogramme glial cells in vivo into neural stem cells.

Our data showed that the ectopic ia-2 and dilp-6 induced neural stem cells could divide and generate neurons. Dilp-6 induced glial-derived Dpn+ cells also expressed the S-phase marker PCNAGFP, and la-2 also induced mitosis in midline glia. We could not detect mitotic cells surrounding the neuropile, but mitosis is brief, and could have easily been missed. The Dilp-6 induced ectopic Dpn+ cells could generate neurons that could be traced with GFP expression from their glial origin. Thus, ectopic neural stem cells induced by Dilp-6 can divide and produce neuronal progeny cells. However, the clusters of GFP+ cells originating from the in vivo reprogrammed glial cells were rather small, indicating that although neurogenesis is possible in the late larvae, it is extremely constrained. This could be due to the context of the Drosophila larva, where time is limited by pupariation. Injury and genetic manipulation in late larvae may not allow sufficient time for cell lineages to progress, before pupariation starts. Pupariation and metamorphosis bring in a different cellular context, which could interefere with regenerative neuronal differentiation. Alternatively, la-2 and Dpn may not be sufficient to carry neurogenesis through either. For instance, gain of ia-2 function resulted only in Dpn+ but not Pros+ or Eve+ cells, suggesting that la-2 and Dpn are not sufficient for neuroblasts to progress to ganglion mother cells and neurons. Furthermore, ectopic Dpn+ cells still had Repo. To generate neurons, glia may not only require the expression of neural stem cell markers such as $d p n$, but also to receive other yet unknown signals (Figure 10B). In mammals, injury creates a distinct 
cellular environment that prompts glial cells to generate different cell types than in the un-injured CNS. For instance, elevated Sox-2 is sufficient to directly reprogramme NG2-glia into neurons, but only upon injury (Heinrich et al. 2014). Whereas during normal development NG2-glial cells may only produce oligodendrocyte lineage cells, upon injury they can also produce astrocytes and neurons (Dimou and Gallo 2015; Huang et al. 2018). This suggests that there are injury-induced cues for neuronal differentiation. In the future, it will be compelling to find out what signals could enhance neurogenesis from glial cells reprogrammed in vivo by insulin signalling.

Our work has revealed a novel molecular mechanism driving a regenerative neurogenic response from glia, involving Kon/NG2 and insulin signaling. la-2 induces an initial secretion of Dilp-6 from neurons, Dilp-6 is received by glia, and a positive feedback loop amplifies the Kon-dependent production of Dilp- 6 by cortex glia, Dilp- 6 is then relayed to neuropile glia, resulting in the in vivo reprogramming of glial cells into neural stem cells. This mechanism can induce both glial regeneration and neural stem cells from glia, potentially also neurons, matching interacting neuronal and glial cell populations. Not all neuropile glia were necessarily converted to neural stem cells, meaning the process is stochastic. Such a mechanism may also operate in mammals. In fact, la-2 has universal functions in dense core vesicles to release insulin (Cai et al. 2001; Harashima et al. 2005; Kim et al. 2008; Nishimura et al. 2010; Cai et al. 2011). Insulin-like growth factor 1 (IGF-1) induces the production of astrocytes, oligodendrocytes and neurons from progenitor cells in the adult brain, in response to exercise (Nieto-Estevez et al. 2016; Mir et al. 2017). The transcription factor Sox-2 that can switch astrocytes to neural stem cells and produce neurons, is a downstream effector of InR/AKT signaling (Mir et al. 2017). NG2 also interacts with downstream components of the InR signalling pathway (e.g. PI3K-Akt-mTOR) to promote cell cycle progression and regulate the expression of its downstream effectors in a positive feedback loop (Sakry et al. 2015; Nayak et al. 2018). Together, all of these findings indicate that la-2, NG2/Kon and insulin signaling have a common function across animals in reprogramming glial cells into becoming neural stem cells. 
Intriguingly, $d p n$ was only induced in neuropile associated glial cells, but not other glial types, thus perhaps only the former have neurogenic potential. Of the neuropile glia, Drosophila "astrocytes" and midline glia express Notch, pros and kon, as well as $\ln R$. The cells frequently called "astrocytes" share features with mammalian NG2-glia (Losada-Perez et al. 2016; Hidalgo and Logan 2017; Kato et al. 2018). In mammals, the combination of Notch1, Prox1 and NG2 is unique to NG2glia, and is absent from astrocytes (Cahoy et al. 2008). Perhaps la-2 and Dilp-6 can only induce neural stem cells from NG2-like glia bearing this combination of factors. Notch activates glial proliferation and kon expression in Drosophila (Losada-Perez et al. 2016), and in the mammalian CNS, Notch promotes NG2-glia proliferation and maintains the progenitor state, whereas its downregulation is required to induce both glial and neuronal differentiation (Yamamoto et al. 2001; Ables et al. 2010; Piccin et al. 2013; Falk and Gotz 2017). In Drosophila, Notch and Pros also regulate dpn expression: Notch activates $d p n$ expression promoting stemness, and Pros inhibits it, promoting transition to ganglion mother cell and neuron (Vaessin et al. 1991; San-Juan and Baonza 2011; Babaoglan et al. 2013; Bi and Kuang 2015). Thus, only glial cells with Notch and Pros may be poised to modulate stemness and neuronal differentiation. We showed that $I n R$ is expressed in neuropile glia, and insulin signaling represses FoxO, which represses $d p n$, thus ultimately activates $d p n$ expression (Siegrist et al. 2010). As Notch and insulin signaling positively regulate dpn expression (Vaessin et al. 1991; Siegrist et al. 2010; San-Juan and Baonza 2011; Babaoglan et al. 2013; Bi and Kuang 2015), and injury induces a Notch-dependent up-regulation of Kon (Losada-Perez et al. 2016), which activates dilp-6 expression, and of la-2, which secretes Dilp-6, our data indicate that Notch-Kon/NG2-insulin synergy triggers the activation of $d p n$ expression. Importantly, we found no evidence that Kon functions in neural stem cells. Thus, perhaps induced neural stem cells can generate only glia from daughter cells that inherit Kon, on which Repo and glial cell fate depend, or generate neurons, from daughter cells that lack Kon, but have Pros, on which la-2 depends (Figure 10B). Thus, upon injury, Notch, Pros, Kon/NG2, la-2 and insulin signalling function together to enable the regenerative production of both glial cells, and neural stem cells from glia (Figure 10B,C). 
To conclude, a neuron-glia communication relay involving la-2, Dilp-6, Kon and InR is responsible for the induction of the neural stem cells from glia, their proliferation and limited neurogenesis. Neuronal la-2 and Dilp-6 trigger two distinct responses in glia: 1) in cortex glial cells, insulin signaling boosts Kon-dependent amplification of Dilp-6, glial proliferation and glial regeneration; 2) in neuropile-associated NG2-like glial cells, la-2 and Dilp-6 also unlock a neurogenic response, inducing neural stem cell fate. As a result, these genes can drive the production of both glial cells and neurons after injury, enabling the matching of interacting cell populations, which is essential for regeneration.

\section{MATERIALS AND METHODS}

Fly stocks and genetics. Fly stocks used are listed in Table 1 below. Stocks carrying combinations of over-expression and RNAi, or RNAi and mutants, etc., were generated by conventional genetics. $\mathrm{N}^{\text {ts }}$ mutants were raised at $18^{\circ} \mathrm{C}$ to enable normal embryogenesis, and switched to $25^{\circ} \mathrm{C}$ from larval hatching to the third instar larval wandering stage to cause $\mathrm{N}$ loss of function. For all experiments, larvae bearing balancer chromosomes were identified by either using the fluorescent balancers CyO Dfd-YFP and TM6B Dfd-YFP or using the balancer SM6a-TM6B Tb ${ }^{-}$, which balances both the second and third chromosomes, and discarded. For the genetic screens, larvae with fluoresencent VNCs (i.e. repoGAL4>UAS-FlyBow or elavGAL4>UAS-FlyBow) were selected.

Crush injury in the larval VNC. Crush injury in the larval CNS was carried out as previously reported (Losada-Perez et al. 2016), and only lesions in the abdominal VNC were analysed. Larval collections were staged by putting the $\mathrm{GO}$ flies in an egg laying chamber for $2 \mathrm{~h}$, then collecting the $\mathrm{F} 1$ larve some time later, as indicated next. Larvae were placed on a chilled petri-dish with agar over ice. Crush injury was carried out by pinching with fine forceps the GFP-bearing VNCs under UV light using a fluorescence dissecting microscope: (1) at 74-76h after egg laying (AEL); VNCs were then left to carry on developing at $25^{\circ} \mathrm{C}$, and were dissected either $5-7 \mathrm{~h}$ or $24 \mathrm{~h}$ post-injury (PI); (2) at $96 \mathrm{~h}$, kept at $25^{\circ} \mathrm{C}$ 
and dissected and fixed $6 \mathrm{~h} \mathrm{PI}$; (3) at $105 \mathrm{~h} \mathrm{AEL}$, kept at $25^{\circ} \mathrm{C}$ and dissected $24 \mathrm{~h} \mathrm{PI}$; (4) at $117 \mathrm{~h} \mathrm{AEL}$, kept at $25^{\circ} \mathrm{C}$, and dissected $12 \mathrm{~h} \mathrm{PI}$. Dissected and fixed VNC were then processed for antibody stainings following standard procedures.

\section{Molecular cloning}

The UAS-konICD-HA construct was generated from EST LD31354 via PCR amplification with Kappa HiFi PCR kit (Peqlab) and subsequent cloning using the Gateway cloning system (Invitrogen) according to manufacturers instructions. Primers used were kon ${ }^{\mathrm{ICD}}$ fwd comprising the CACCsequence at the $5^{\prime}$-end (CCACAGGAAACTGAGAAAGCACAAGGC) for direct cloning of the PCR product (482 bp) into the entry vector pENTR/D-Topo, and kon ${ }^{\text {ICD }}$ rev (AAACCTTACACCCAATACTGATTCC) including the endogenous stop-codon, underlined. Destination vector was pTHW for tagging the ICD on the $\mathrm{N}$-terminus with $\mathrm{HA}$, including a $5 x \mathrm{x}$ AS cassette and P-element ends for transformation. These destination vectors were developed by the Murphy-Lab at Carnegie Institution of Science, Baltimore, MD, USA, and can be obtained from the Drosophila Genomics Resource Center at Indiana University, USA. Transformant fly strains were generated by BestGene Inc, Chino Hills, CA, USA following a standard tranposase-mediated germline transformation protocol.

A UAS-ia-2 construct was generated using Gateway cloning (Invitrogen, as above). la-2 cDNA was generated by reverse-transcription PCR of purified mRNA from Oregon R flies, and cloned into pDONR. Subsequently, a standard PCR amplification was performed using Phusion High-Fidelity (Fisher Scientific), primers la-2F (5' - ATGGCACGCAATGTACAACAACGGC) and ia-2-stopR (5' CTTCTTCGCCTGCTTCGCCGATTTG), and the resulting PCR product (3918bp) was cloned into pGEM ${ }^{\circledR}-T^{-}$ Easy Vector (Promega). Subsequently, a Phusion High Fidelity PCR amplification was carried out using Gateway primers la-2attB F1 (5' ggggacaagtttgtacaaaaaagcaggcttcATGGCACGCAATGTACAACAACGGC) and la-2attB R1 (5' ggggaccactttgtacaagaaagctgggtcCTTCTTCGCCTGCTTCGCCGATTTG), and plasmid pGEM-ia-2 as template. Using Gateway cloning, the PCR product (3979bp) was cloned first into pDONR ${ }^{221}$ and 
subsequently into the pUAS-gw-attB destination vector, for $\phi C 31$ transgenesis. The construct was injected by BestGene Inc. to generate transgenic flies bearing UAS-ia-2 at the attP2 landing site.

\section{Quantitative real time reverse transcription PCR (qRT-PCR).}

qRT-PCR was preformed according to standard methods and as previously described (Losada-Perez et al. 2016), with the following alteration. For each sample, 10 third instar larvae were used per genotype per replicate. At least three independent biological replicates were performed for all experiments other than in Figure 1-Figure supplement $3 \mathrm{~A}$ and $\mathrm{B}$ where two replicates were carried out on all candidates and those of interest where taken forward to carry out two further replicates. For a list of the primers used in this study please see Key Resources Table below.

Immunostainings were carried out following standard procedures. The following primary antibodies were used: mouse anti-Repo (1:100, DSHB); guinea pig anti-Repo (1:1000, Ben Altenhein); rat antiElav (1:250, DSHB); mouse anti-FasII ID4 (1:500, DSHB); mouse anti-Prospero (1:250, DSHB); guinea pig anti-Dpn (1:1000, gift of J. Skeath); mouse anti-Eve 3C10 (1:20, DSHB); rabbit anti-phosphohistone-H3 (1:250); rabbit anti-HA (1:1600, Cell Signalling Technology); rabbit anti-GFP at 1:250 (Molecular Probes); mouse anti-Wrapper (1:5, DSHB). Secondary antibodies were Alexa conjugated: Donkey anti-rabbit 488 (1:250, Molecular Probes), goat anti-rabbit 488 (1:250, Molecular Probes), goat anti-rabbit 647 (1:250, Molecular Probes), goat anti-mouse 488 (1:250, Molecular Probes), goat anti-mouse 546 (1:250, Molecular Probes), goat anti-mouse 647 (1:250, Molecular Probes), goat antirat 546 (1:250, Molecular Probes), goat anti-guinea pig 488 (1:250, Molecular Probes), goat antiguinea pig 633 (1:250, Molecular Probes), goat anti-rat 647 and 660 (1:250, Molecular Probes ).

Microscopy and imaging. Image data were acquired using a Zeiss LSM710 laser scanning confocal microscope, with 25x lens and 1.00 zoom, an Olympus Fluoview FV1000, 20x lens, and a Leica SP8 laser scanning confocal microscope, with a $20 x$ lens, 1.25 zoom. All images were taken with 
resolution $512 \times 512$ or $1024 \times 1024$, step $0.96 \mu \mathrm{m}$ and $1-3 \times$ averaging for all samples except for cell counting with DeadEasy that have no averaging.

Images were analysed using ImageJ. Images of horizontal sections are projections from the stacks of confocal images that span the thickness of the entire VNC, using ImageJ. Transverse views were generated using the Reslice option. Images were processed using Adobe Creative Suite 6 Photoshop and compiled with Adobe Illustrator.

\section{Automatic cell counting}

Glial cells labelled either with anti-Repo or with repoGAL4>UAShistone-YFP were counted automatically in 3D across the thickness of the VNC using DeadEasy Larval Glia software, as previously described. Prospero+ and Dpn+ cells were counted manually in 3D (i.e. not in projections), as the signal was noisy for DeadEasy.

\section{Statistical analysis}

Statistical analysis was carried out using Graphpad Prism. All data in this work are continuous, except for the PCNAGFP data in Figure $8 \mathrm{H}$ which are categorical. The latter were analysed with a nonparametric Fisher's exact test. For all other data, tests to determine whether data were distributed normally and variances were equal were initially carried out, and thereafter if so, parametric One Way ANOVA tests where carried out when comparing more than two sample types group. Multiple comparison corrections were carried out with post-hoc Dunnett tests comparisons to set controls, or Bonferroni comparisons of all samples against all. Box plots were used to represent the distribution of continuous data, where the line within the box represents the median of the data distribution, the box comprises the 25 percentiles above and below the median, and the whiskers the lowest and highest 25 percentiles. 
bioRxiv preprint doi: https://doi.org/10.1101/721498; this version posted June 22,2020 . The copyright holder for this preprint (which was

not certified by peer review) is the author/funder, who has granted bioRxiv a license to display the preprint in perpetuity. It is made available under aCC-BY 4.0 International license.

We thank our labs and C. Rezaval for discussions and comments on the manuscript; S. Corneliussen, T. Schunke and S. Dietz for technical help; Y. Fan, A. Gould, Y. Jan, Y. Nung, J. Skeath and F. Schnorrer for reagents; A. Di Maio and Birmingham Advanced Light Microscopy for assistance; Bloomington Drosophila Stock Centre for fruit-flies and Developmental Studies Hybridoma Bank, lowa for antibodies.

\section{FUNDING}

This work was funded by BBSRC Project Grants BB/L008343/1 and BB/R00871X/1 to A.H., and BBSRC MIBTP PhD studentship to E.C.

\section{REFERENCES}

Ables, J. L., Decarolis, N. A., Johnson, M. A., Rivera, P. D., Gao, Z., Cooper, D. C., Radtke, F., Hsieh, J. and Eisch, A. J. (2010). "Notch1 is required for maintenance of the reservoir of adult hippocampal stem cells." J Neurosci 30(31): 10484-10492.

Babaoglan, A. B., Housden, B. E., Furriols, M. and Bray, S. J. (2013). "Deadpan contributes to the robustness of the notch response." PLoS One 8(9): e75632.

Bayraktar, O. A., Boone, J. Q., Drummond, M. L. and Doe, C. Q. (2010). "Drosophila type II neuroblast lineages keep Prospero levels low to generate large clones that contribute to the adult brain central complex." Neural Dev 5: 26.

Bello, B. C., Hirth, F. and Gould, A. P. (2003). "A pulse of the Drosophila Hox protein Abdominal-A schedules the end of neural proliferation via neuroblast apoptosis." Neuron 37(2): 209-219.

$\mathrm{Bi}, \mathrm{P}$. and Kuang, S. (2015). "Notch signaling as a novel regulator of metabolism." Trends Endocrinol Metab 26(5): 248-255.

Biname, F., Sakry, D., Dimou, L., Jolivel, V. and Trotter, J. (2013). "NG2 regulates directional migration of oligodendrocyte precursor cells via Rho GTPases and polarity complex proteins." J Neurosci 33(26): 10858-10874.

Boone, J. Q. and Doe, C. Q. (2008). "Identification of Drosophila type II neuroblast lineages containing transit amplifying ganglion mother cells." Dev Neurobiol 68(9): 1185-1195.

Cahoy, J. D., Emery, B., Kaushal, A., Foo, L. C., Zamanian, J. L., Christopherson, K. S., Xing, Y., Lubischer, J. L., Krieg, P. A., Krupenko, S. A., Thompson, W. J. and Barres, B. A. (2008). "A 
transcriptome database for astrocytes, neurons, and oligodendrocytes: a new resource for understanding brain development and function." J Neurosci 28(1): 264-278.

Cai, T., Hirai, H., Fukushige, T., Yu, P., Zhang, G., Notkins, A. L. and Krause, M. (2009). "Loss of the transcriptional repressor PAG-3/Gfi-1 results in enhanced neurosecretion that is dependent on the dense-core vesicle membrane protein IDA-1/IA-2." PLoS Genet 5(4): e1000447.

Cai, T., Hirai, H., Zhang, G., Zhang, M., Takahashi, N., Kasai, H., Satin, L. S., Leapman, R. D. and Notkins, A. L. (2011). "Deletion of la-2 and/or la-2beta in mice decreases insulin secretion by reducing the number of dense core vesicles." Diabetologia 54(9): 2347-2357.

Cai, T., Krause, M. W., Odenwald, W. F., Toyama, R. and Notkins, A. L. (2001). "The IA-2 gene family: homologs in Caenorhabditis elegans, Drosophila and zebrafish." Diabetologia 44(1): 81-88.

Carmona, G. N., Nishimura, T., Schindler, C. W., Panlilio, L. V. and Notkins, A. L. (2014). "The dense core vesicle protein IA-2, but not IA-2 beta, is required for active avoidance learning." Neuroscience 269: 35-42.

Chell, J. M. and Brand, A. H. (2010). "Nutrition-responsive glia control exit of neural stem cells from quiescence." Cell 143(7): 1161-1173.

Dimou, L. and Gallo, V. (2015). "NG2-glia and their functions in the central nervous system." Glia 63(8): 1429-1451.

Dimou, L. and Gotz, M. (2014). "Glial cells as progenitors and stem cells: new roles in the healthy and diseased brain." Physiol Rev 94(3): 709-737.

Du, X., Zhang, Z., Zhou, H. and Zhou, J. (2020). "Differential Modulators of NG2-Glia Differentiation into Neurons and Glia and Their Crosstalk." Cell Mol Neurobiol, 10.1007/s10571-020-00843-0.

Estrada, B., Gisselbrecht, S. S. and Michelson, A. M. (2007). "The transmembrane protein Perdido interacts with Grip and integrins to mediate myotube projection and attachment in the Drosophila embryo." Development 134(24): 4469-4478.

Falk, S. and Gotz, M. (2017). "Glial control of neurogenesis." Curr Opin Neurobiol 47: 188-195.

Fernandes, V. M., Chen, Z., Rossi, A. M., Zipfel, J. and Desplan, C. (2017). "Glia relay differentiation cues to coordinate neuronal development in Drosophila." Science 357(6354): 886-891.

Fernandez, R., Tabarini, D., Azpiazu, N., Frasch, M. and Schlessinger, J. (1995). "The Drosophila insulin receptor homolog: a gene essential for embryonic development encodes two receptor isoforms with different signaling potential." EMBO J 14(14): 3373-3384.

Forero, M. G., Kato, K. and Hidalgo, A. (2012). "Automatic cell counting in vivo in the larval nervous system of Drosophila." J Microsc 246(2): 202-212. 
Froldi, F., Szuperak, M., Weng, C. F., Shi, W., Papenfuss, A. T. and Cheng, L. Y. (2015). "The transcription factor Nerfin-1 prevents reversion of neurons into neural stem cells." Genes Dev 29(2): 129-143.

Gage, F. H. (2019). "Adult neurogenesis in mammals." Science 364(6443): 827-828.

Gil-Ranedo, J., Gonzaga, E., Jaworek, K. J., Berger, C., Bossing, T. and Barros, C. S. (2019). "STRIPAK Members Orchestrate Hippo and Insulin Receptor Signaling to Promote Neural Stem Cell Reactivation." Cell Rep 27(10): 2921-2933 e2925.

Griffiths, R. L. and Hidalgo, A. (2004). "Prospero maintains the mitotic potential of glial precursors enabling them to respond to neurons." EMBO J 23(12): 2440-2450.

Harashima, S., Clark, A., Christie, M. R. and Notkins, A. L. (2005). "The dense core transmembrane vesicle protein IA-2 is a regulator of vesicle number and insulin secretion." Proc Nat/ Acad Sci U S A 102(24): 8704-8709.

Heinrich, C., Bergami, M., Gascon, S., Lepier, A., Vigano, F., Dimou, L., Sutor, B., Berninger, B. and Gotz, M. (2014). "Sox2-mediated conversion of NG2 glia into induced neurons in the injured adult cerebral cortex." Stem Cell Reports 3(6): 1000-1014.

Henquin, J. C., Nenquin, M., Szollosi, A., Kubosaki, A. and Notkins, A. L. (2008). "Insulin secretion in islets from mice with a double knockout for the dense core vesicle proteins islet antigen-2 (IA-2) and IA-2beta." J Endocrinol 196(3): 573-581.

Hidalgo, A. and Logan, A. (2017). "Go and stop signals for glial regeneration." Curr Opin Neurobiol 47: 182-187.

Hu, Y. F., Zhang, H. L., Cai, T., Harashima, S. and Notkins, A. L. (2005). "The IA-2 interactome." Diabetologia 48(12): 2576-2581.

Huang, W., Bai, X., Stopper, L., Catalin, B., Cartarozzi, L. P., Scheller, A. and Kirchhoff, F. (2018). "During Development NG2 Glial Cells of the Spinal Cord are Restricted to the Oligodendrocyte Lineage, but Generate Astrocytes upon Acute Injury." Neuroscience 385: 154-165.

Kato, K., Forero, M. G., Fenton, J. C. and Hidalgo, A. (2011). "The glial regenerative response to central nervous system injury is enabled by pros-notch and pros-NFkappaB feedback." PLoS Biol 9(8): e1001133.

Kato, K., Konno, D., Berry, M., Matsuzaki, F., Logan, A. and Hidalgo, A. (2015). "Prox1 Inhibits Proliferation and Is Required for Differentiation of the Oligodendrocyte Cell Lineage in the Mouse." PLoS One 10(12): e0145334.

Kato, K., Losada-Perez, M. and Hidalgo, A. (2018). "Gene network underlying the glial regenerative response to central nervous system injury." Dev Dyn 247(1): 85-93. 
Kim, J., Bang, H., Ko, S., Jung, I., Hong, H. and Kim-Ha, J. (2008). "Drosophila ia2 modulates secretion of insulin-like peptide." Comp Biochem Physiol A Mol Integr Physiol 151(2): 180-184.

Kucharova, K., Chang, Y., Boor, A., Yong, V. W. and Stallcup, W. B. (2011). "Reduced inflammation accompanies diminished myelin damage and repair in the NG2 null mouse spinal cord." J Neuroinflammation 8: 158.

Kucharova, K. and Stallcup, W. B. (2010). "The NG2 proteoglycan promotes oligodendrocyte progenitor proliferation and developmental myelination." Neuroscience 166(1): 185-194.

Losada-Perez, M., Harrison, N. and Hidalgo, A. (2016). "Molecular mechanism of central nervous system repair by the Drosophila NG2 homologue kon-tiki." J Cell Biol 214(5): 587-601.

Lowe, N., Rees, J. S., Roote, J., Ryder, E., Armean, I. M., Johnson, G., Drummond, E., Spriggs, H., Drummond, J., Magbanua, J. P., Naylor, H., Sanson, B., Bastock, R., Huelsmann, S., Trovisco, V., Landgraf, M., Knowles-Barley, S., Armstrong, J. D., White-Cooper, H., Hansen, C., Phillips, R. G., Consortium, U. K. D. P. T. S., Lilley, K. S., Russell, S. and St Johnston, D. (2014). "Analysis of the expression patterns, subcellular localisations and interaction partners of Drosophila proteins using a pigP protein trap library." Development 141(20): 3994-4005.

Lye, C. M., Naylor, H. W. and Sanson, B. (2014). "Subcellular localisations of the CPTI collection of YFP-tagged proteins in Drosophila embryos." Development 141(20): 4006-4017.

Mir, S., Cai, W., Carlson, S. W., Saatman, K. E. and Andres, D. A. (2017). "IGF-1 mediated Neurogenesis Involves a Novel RIT1/Akt/Sox2 Cascade." Sci Rep 7(1): 3283.

Mooney, R. A., Kulas, D. T., Bleyle, L. A. and Novak, J. S. (1997). "The protein tyrosine phosphatase LAR has a major impact on insulin receptor dephosphorylation." Biochem Biophys Res Commun 235(3): 709-712.

Nayak, T., Trotter, J. and Sakry, D. (2018). "The Intracellular Cleavage Product of the NG2 Proteoglycan Modulates Translation and Cell-Cycle Kinetics via Effects on mTORC1/FMRP Signaling." Front Cell Neurosci 12: 231.

Nieto-Estevez, V., Defterali, C. and Vicario-Abejon, C. (2016). "IGF-I: A Key Growth Factor that Regulates Neurogenesis and Synaptogenesis from Embryonic to Adult Stages of the Brain." Front Neurosci 10: 52.

Nishimura, T., Harashima, S., Yafang, H. and Notkins, A. L. (2010). "IA-2 modulates dopamine secretion in PC12 cells." Mol Cell Endocrinol 315(1-2): 81-86.

Pereira, M., Birtele, M., Shrigley, S., Benitez, J. A., Hedlund, E., Parmar, M. and Ottosson, D. R. (2017). "Direct Reprogramming of Resident NG2 Glia into Neurons with Properties of Fast-Spiking Parvalbumin-Containing Interneurons." Stem Cell Reports 9(3): 742-751. 
Perez-Moreno, J. J., Espina-Zambrano, A. G., Garcia-Calderon, C. B. and Estrada, B. (2017). "Kon-tiki enhances PS2 integrin adhesion and localizes its ligand, Thrombospondin, in the myotendinous junction." J Cell Sci 130(5): 950-962.

Peron, S. and Berninger, B. (2015). "Reawakening the sleeping beauty in the adult brain: neurogenesis from parenchymal glia." Curr Opin Genet Dev 34: 46-53.

Piccin, D., Yu, F. and Morshead, C. M. (2013). "Notch signaling imparts and preserves neural stem characteristics in the adult brain." Stem Cells Dev 22(10): 1541-1550.

Sakry, D., Neitz, A., Singh, J., Frischknecht, R., Marongiu, D., Biname, F., Perera, S. S., Endres, K., Lutz, B., Radyushkin, K., Trotter, J. and Mittmann, T. (2014). "Oligodendrocyte precursor cells modulate the neuronal network by activity-dependent ectodomain cleavage of glial NG2." PLoS Biol 12(11): e1001993.

Sakry, D. and Trotter, J. (2016). "The role of the NG2 proteoglycan in OPC and CNS network function." Brain Res 1638(Pt B): 161-166.

Sakry, D., Yigit, H., Dimou, L. and Trotter, J. (2015). "Oligodendrocyte precursor cells synthesize neuromodulatory factors." PLoS One 10(5): e0127222.

San-Juan, B. P. and Baonza, A. (2011). "The bHLH factor deadpan is a direct target of Notch signaling and regulates neuroblast self-renewal in Drosophila." Dev Biol 352(1): 70-82.

Schnorrer, F., Kalchhauser, I. and Dickson, B. J. (2007). "The transmembrane protein Kon-tiki couples to Dgrip to mediate myotube targeting in Drosophila." Dev Cell 12(5): 751-766.

Shtaya, A., Sadek, A. R., Zaben, M., Seifert, G., Pringle, A., Steinhauser, C. and Gray, W. P. (2018). "AMPA receptors and seizures mediate hippocampal radial glia-like stem cell proliferation." Glia 66(11): 2397-2413.

Siegrist, S. E., Haque, N. S., Chen, C. H., Hay, B. A. and Hariharan, I. K. (2010). "Inactivation of both Foxo and reaper promotes long-term adult neurogenesis in Drosophila." Curr Biol 20(7): 643648.

Simoes, A. R. and Rhiner, C. (2017). "A Cold-Blooded View on Adult Neurogenesis." Front Neurosci 11: 327.

Song, J., Wu, L., Chen, Z., Kohanski, R. A. and Pick, L. (2003). "Axons guided by insulin receptor in Drosophila visual system." Science 300(5618): 502-505.

Song, Y., Ori-McKenney, K. M., Zheng, Y., Han, C., Jan, L. Y. and Jan, Y. N. (2012). "Regeneration of Drosophila sensory neuron axons and dendrites is regulated by the Akt pathway involving Pten and microRNA bantam." Genes Dev 26(14): 1612-1625.

Sousa-Nunes, R., Yee, L. L. and Gould, A. P. (2011). "Fat cells reactivate quiescent neuroblasts via TOR and glial insulin relays in Drosophila." Nature 471(7339): 508-512. 
Sun, W., Matthews, E. A., Nicolas, V., Schoch, S. and Dietrich, D. (2016). "NG2 glial cells integrate synaptic input in global and dendritic calcium signals." Elife 5.

Tanaka, E. M. and Ferretti, P. (2009). "Considering the evolution of regeneration in the central nervous system." Nat Rev Neurosci 10(10): 713-723.

Torper, O., Ottosson, D. R., Pereira, M., Lau, S., Cardoso, T., Grealish, S. and Parmar, M. (2015). "In Vivo Reprogramming of Striatal NG2 Glia into Functional Neurons that Integrate into Local Host Circuitry." Cell Rep 12(3): 474-481.

Vaessin, H., Grell, E., Wolff, E., Bier, E., Jan, L. Y. and Jan, Y. N. (1991). "prospero is expressed in neuronal precursors and encodes a nuclear protein that is involved in the control of axonal outgrowth in Drosophila." Cell 67(5): 941-953.

Valny, M., Honsa, P., Kriska, J. and Anderova, M. (2017). "Multipotency and therapeutic potential of NG2 cells." Biochem Pharmacol 141: 42-55.

van der Heide, L. P., Ramakers, G. M. and Smidt, M. P. (2006). "Insulin signaling in the central nervous system: learning to survive." Prog Neurobiol 79(4): 205-221.

Vigano, F. and Dimou, L. (2016). "The heterogeneous nature of NG2-glia." Brain Res 1638(Pt B): 129137.

Wills, Z., Bateman, J., Korey, C. A., Comer, A. and Van Vactor, D. (1999). "The tyrosine kinase Abl and its substrate enabled collaborate with the receptor phosphatase Dlar to control motor axon guidance." Neuron 22(2): 301-312.

Yamamoto, S., Nagao, M., Sugimori, M., Kosako, H., Nakatomi, H., Yamamoto, N., Takebayashi, H., Nabeshima, Y., Kitamura, T., Weinmaster, G., Nakamura, K. and Nakafuku, M. (2001). "Transcription factor expression and Notch-dependent regulation of neural progenitors in the adult rat spinal cord." J Neurosci 21(24): 9814-9823.

\section{FIGURE LEGENDS}

\section{FIGURE $1 \quad i a-2$ interacts genetically with kon, Notch and pros.}

(A) Quantitative real-time PCR (qRT-PCR) showing that gain of kon function reduced ia-2 mRNA levels by $25 \%$ (One Way ANOVA $p=0.045$ ), whereas loss of kon function in glia caused practically a 3 -fold increase in ia-2 mRNA levels (genotype: kon ${ }^{c 452} /$ UASkonRNAi; repoGAL4/+; One Way ANOVA p<0.0001). Post-hoc Dunnett's test multiple comparisons to control. $N=4$ replicates. (B) qRT-PCR showing that over-expression of $i a-2$ in glia downregulated kon mRNA levels. Left: Unpaired Student t-test with Welch correction $p=0.457$. Right: One Way ANOVA $p<0.045$, post-hoc Dunnett's test 
multiple comparisons to control. $\mathrm{N}=4-6$ replicates. (C) la-2 is functionally related to Notch: qRT-PCR showing that ia-2 mRNA levels increased in $N^{t s}$ mutant larvae at the restrictive temperature of $25^{\circ} \mathrm{C}$. Unpaired Student t-test with Welch correction Left: $p=0.4123$; Right: $p=0.2182$. $N=3$ replicates. (D) ia2 is functionally related to pros: qRT-PCR showing that over-expression of pros in glia increased ia-2 mRNA levels by 2 -fold. Unpaired Student $t$-test with Welch correction. Left: $p=0.1368$; Right: $p=0.0428 . \mathrm{N}=3$ replicates. (E) qRT-PCR showing that UAS-ia-2 RNAi[TRIPHMS00536] knock-down in neurons (with elavGAL4) lowered ia-2 mRNA levels to $20 \%$, whereas in glia it has no effect, meaning that ia-2 is expressed in neurons. A second UAS-ia-2RNAi[KK108555-VIE-260B] line lowered mRNA levels by $25 \%$. One Way ANOVA $p=0.0004$, post-hoc multiple comparisons to control Dunnett's test. $\mathrm{N}=3$ replicates. $(\mathbf{F}, \mathbf{G}, \mathbf{H})$ Fusion protein la-2YFP revealed expression exclusively in neurons, as all la2YFP+ cells were also Elav+, but Repo ${ }^{-}$and $\mathrm{Dpn}^{-}$. Genotype: ia-2[CPTI100013]. N=4-16 larval VNCs. (I) Illustration showing that kon and ia-2 functions are restricted to glia and neurons, respectively, and they mutually exclude each other. (G) transverse views; $(\mathbf{F}, \mathbf{H})$ horizontal views; $(\mathbf{H})$ higher magnification views). With more than two sample types, asterisks indicate multiple comparison posthoc tests to controls: ${ }^{*} p<0.05,{ }^{* *} p<0.01,{ }^{* * *} p<0.001,{ }^{* * * *} p<0.0001$. For full genotypes and further statistical analysis details see Table Supplement 1.

FIGURE 2 ia-2 influences neural cell fate non-autonomously. $(A, B)$ Loss of kon function in glia

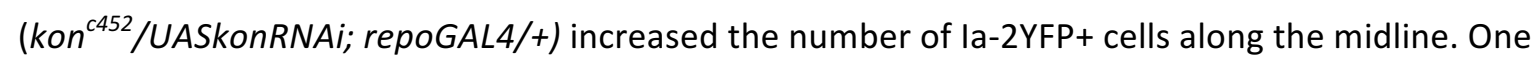
Way ANOVA p $<0.0001$, post-hoc Tukey's test. N=5-8 VNCs. (C) The ectopic la-2YFP+ cells in kon loss of function were Elav+ and not Repo+. N=5-7 VNCs. (D, E) Neither loss nor gain of ia-2 function affected the number of Eve+ neurons. One Way ANOVA $p=0.2374 . \mathrm{N}=7-12$ VNCs. $(\mathbf{F}, \mathbf{G})$ Loss of $i a-2$ function (elavGAL4>UASia-2RNAi[TRIPHSM00536]) increased Pros+ cell number, and the excess cells were small. Kruskal-Wallis ANOVA $p=0.0003$, post-hoc Dunnett's test. $\mathrm{N}=8-10$ VNCs. $(\mathbf{H})$ The small Pros+ cells in ia-2 knock-down did not have the glial marker Repo. $(\mathbf{I}, \mathrm{J}) \mathrm{Dpn}+$ cells visualised at $120 \mathrm{~h}$ AEL, after developmental neuroblasts have disappeared. Both loss and gain of ia-2 function increased 
Dpn+ cell number. All images are horizontal views, except for (I bottom row) which are transverse views. One Way ANOVA $\mathrm{p}=0.0002$, post-hoc Dunnett. $\mathrm{N}=7-15$. Asterisks indicate multiple comparison post-hoc tests to a fixed control: ${ }^{*} p<0.05,{ }^{* *} p<0.01,{ }^{* * *} p<0.001,{ }^{* * * *} p<0.0001$. For further statistical analysis details see Table Supplement 1.

FIGURE 3 Injury induced ia-2 expression and ectopic Dpn+ cells. (A,B,E) Time course of crushinjury experiments, indicating the age of the larvae (After Egg Laying, AEL) when crush was applied (top arrows), followed by various recovery periods, and when they were fixed or processed (bottom arrows). (C) Drawing showing that crush injury induced ectopic Dpn+ cells. (D, F,G,H) Crush injury in the larval abdominal VNC at 74-76h after egg laying (AEL) caused: (D) an increase in the levels of ia-2 mRNA at $5-7$ h post-injury, which recovered homeostatically by $24 \mathrm{~h}$, detected by qRT-PCR. $\mathrm{N}=3$ replicates. (F,G,H) Formation of ectopic Dpn+ neural stem cells (white arrowheads) by 5-7 hours post-injury, 74-80h AEL. Quantification in $(\mathbf{H})$ shows number of Dpn+ in VNCs with ectopic Dpn+ cells (Penetrance $50 \% \mathrm{~N}=10 \mathrm{VNCs}$ ), as in some VNC cell loss caused by lesion was very severe. Dpn+ cells were la-2YFP ${ }^{-} .(\mathbf{I}, \mathrm{J}, \mathrm{K})$ Crush injury in the larval abdominal VNC at $96 \mathrm{~h}$ AEL caused ectopic Dpn+ cells by 6 hours post-injury (yellow arrowheads, penetrance $44 \% \mathrm{~N}=9$ VNCs). Most Dpn+ cells were la$2 \mathrm{YFP}^{-}$, but some were la-2YFP ${ }^{+}$. At this stage, some developmental neuroblasts could still remain (white arrows), but dorsal ectopic Dpn+ were unequivocal (yellow arrowheads, J). (K) Student t-test $p=0.0063$. (L) Injury at $105 \mathrm{~h} \mathrm{AEL} \mathrm{visualised} \mathrm{at} 129 \mathrm{~h}$ AEL, when no developmental neuroblasts remain, induced a significant increase in Dpn+ cells. Mann-Whitney U-test $p=0.0375 .(\mathbf{M}, \mathbf{N}, \mathbf{O})$ Crush injury in the larval abdominal VNC at $117 \mathrm{~h}$ AEL caused ectopic Dpn+ cells by 12 hours post-injury (yellow arrowheads, $129 \mathrm{~h}$ AEL, Penetrance $67 \% \mathrm{~N}=21$, VNCs. Student t-test $\mathrm{p}=0.0302$ ). $\mathrm{Dpn}+$ cells were found in ectopic dorsal positions (yellow arrowheads, $\mathbf{N}$ ). This stage is devoid of developmental neural stem cells. $\mathrm{N}=9 / 32$ VNCs. Student t-test. (P) Temporal profile of number of ectopic Dpn+ cells surrounding the lesions, in injured samples with ectopic Dpn+ cells, number in X axis indicate time-points of injury and fixation. $(\mathbf{F}, \mathbf{I}, \mathbf{M})$ Horizontal views, $(\mathbf{G}, \mathbf{J}, \mathbf{N})$ transverse views. $(\mathbf{H}, \mathbf{K}, \mathbf{L}, \mathbf{O})$ Graphs show quantifications 
in box-plots; (P) shows dot plots, with mean and error bars ( \pm s.d.) indicated. ${ }^{*} p<0.05,{ }^{*} p<0.01$. For full genotypes and further statistical analysis details see Table Supplement 1.

FIGURE 4 dilp-6 is expressed in neurons and cortex glia and received by neuropile glia. $(A, B)$ Dilp-6GAL4>UAShisYFP cells are mostly Repo+ $\operatorname{Pros}^{-}$glia that do not surround the neuropile (white arrows), and from position appear to be cortex and surface glia. No YFP+ cells have Pros. Some cells are Repo ${ }^{-}$Pros $^{-}$Elav+ (yellow arrowheads) meaning they are neurons. (C,D) qRT-PCRs showing that: (C) kon knock-down in glia (kon ${ }^{4452} /$ UASkonRNAi; repoGAL4/+) downregulates dilp-6 mRNA levels; (D) over-expression on kon does not cause a significant effect. $\mathrm{N}=3$ replicates for both. (C,D) One Way ANOVA, only differences in (C) for dilp-6 mRNA significant $\mathrm{p}=0.0362,{ }^{*} \mathrm{p}<0.05$. (E,F) inR expression visualized with reporter InR $R^{N P 2552}$ GAL4> UAShistoneYFP is expressed stochastically in some dorsal Repo+ neurople glia (white arrows), and other glia, and in some Elav+ neurons (yellow arrowheads). (A,E) Horizontal views of the abdominal VNC; $(B, F)$ transverse views. For full genotypes and further statistical analysis details see Table Supplement 1.

FIGURE 5 Ia-2, Kon and Dilp-6 are linked though a neuron-glia communication loop. (A) Overexpressed HA-tagged Kon ${ }^{I C D}$ in glia (repoGAL4>UASkon $\left.{ }^{I C d}:: H A\right)$ visualized with anti-HA antibodies in third instar wandering larvae, localizes to both glial cytoplasms and nuclei (arrows). (B,C) Overexpression of either the intracellular domain of either $k o n\left(k o n^{I C D}\right)$ or dilp-6 increased glial cell number, visualized with repoGAL4>UAShistone-YFP, and quantified automatically with DeadEasy in (C). Over-expression of a dominant negative form of the insulin receptor rescues the increase in cell number caused by Dilp-6 (repo>hisYFP, dilp-6, InRDN), meaning that autocrine InR signaling regulates glial proliferation. One Way ANOVA $p<0.0001$, post-hoc Tukey's test multiple comparisons between all samples. $\mathrm{N}=15-28$ VNCs. (D,E) Third star larvae at $72 \mathrm{~h}$ AEL to visualise abdominal developmental neuroblasts: kon-RNAi knock-down in neural stem cells with inscGAL4 does not affect Dpn+ cell number. Unpaired Student t-test, $p=0.3111 . \mathrm{N}=10 \mathrm{VNCs}(\mathrm{F})$ Illustration summarising that a positive 
feedback autocrine loop involving Dilp-6, InR and Kon promotes both glial proliferation and Dilp-6 production. All images are horizontal views. Asterisks refer to multiple comparison post-hoc tests, all samples vs. all: $* * p<0.01, * * * * p<0.0001$. All graphs show box-plots. For full genotypes and further statistical analysis details see Table Supplement 1.

\section{FIGURE $6 \quad$ la-2 and Dilp-6 induce ectopic neural stem cells from InR signaling in glia. All}

samples were analysed at $120 \mathrm{~h} \mathrm{AEL}$, after disappearance of abdominal developmental neuroblasts. (A-C) Over-expression of ia-2 and dilp-6, but not kon-full-length, increased Dpn+cell number in the abdominal VNC. Both la-2 and Dilp-6 induced Dpn+ at the midline and in lateral positions: $i a-2$ most prominently, but not exclusively, along the midline (white arrowhead), and dilp-6 also prominently, but not exclusively, in lateral positions around the neuropile (yellow arrowheads). (C) Ectopic Dpn+ cells did not express la-2YFP (arrowheads). (D) Quantification of all abdominal VNC Dpn+ cells, and genetic epistasis analysis showing that: the increase in Dpn+ cell number caused by ia-2 overexpression was rescued by dilp-6 RNAi and kon-RNAi knock-down in glia, meaning that ia-2 requires Dilp-6 and glial Kon to induce Dpn; and preventing insulin signaling with $\ln \mathrm{R}^{\mathrm{DN}}$ in glia rescued the increase in Dpn+ cell number caused by dilp-6 over-expression, meaning that Dilp-6 induced Dpn via InR signalling in glia. One Way ANOVA $p<0.0001$, post-hoc Tukey's test multiple comparisons all samples vs. all. $\mathrm{N}=7-13$ VNCs. (E) Illustration showing that la-2 and Dilp-6 can induce Dpn via InR signalling in glial cells. (A) Horizontal views; (B) transverse views; (C) higher magnification. Graphs shows quantifications in box-plots. Asterisks refer to multiple comparison post-hoc tests: ${ }^{*} p<0.05$, ${ }^{* * *} p<0.0001, * * * * p<0.0001$. For full genotypes and further statistical analysis details see Table Supplement 1.

FIGURE 7 Ia-2 and Dilp-6 induced ectopic neural stem cells originate from glia. All samples were analysed at $120 \mathrm{~h} \mathrm{AEL}$, after disappearance of abdominal developmental neuroblasts. (A,B) Over-expression of dilp-6 from glia (repoGAL4>UAS-dilp-6) induced Dpn expression in Repo+ 
neuropile glial cells (arrowheads). $\mathrm{N}=10 \mathrm{VNCs}$. (C,D) Over-expressed dilp-6 also induced Dpn in Wrp+ midline glia (arrowheads). N=6 VNCs. (E,F) When dilp-6 was over-expressed, and all glia except midline glia were visualised with nuclear repoGAL4>Histone-YFP and midline glia with anti-Wrp, Dpn+ YFP-Wrp-cells were found, which therefore were not glia (white arrows; yellow arrowheads point to Dpn+Wrp+ cells). N=6 VNCs. $(\mathbf{G}, \mathrm{H})$ G-TRACE expression in glia with repoGAL4 revealed with GFP cells that were originally glia or originated from a glial cell lineage, even if they switched off the glial repo promoter, and with RFP newly generated glial cells. Dpn colocalised in neuropile glia with both GFP and RFP, meaning that Dpn+ cells originated from glia, and at that point in time these cells still retained active the glial repo promoter. $\mathrm{N}=8 \mathrm{VNCs} .(\mathbf{A}, \mathbf{C}, \mathbf{E}, \mathbf{G})$ horizontal and $(\mathbf{B}, \mathbf{D}, \mathbf{F}, \mathbf{H})$ transverse views. For full genotypes and sample sizes see Table Supplement 1.

\section{FIGURE 8} Ia-2 and Dilp-6 induced ectopic neural stem cells can divide. All samples were analysed at $120 \mathrm{~h}$ AEL, after disappearance of abdominal developmental neuroblasts. (A-C', E-G') Cell proliferation was visualised with the S-phase marker PCNA-GFP, quantification in (D,H). dilp-6 expression was induced in all cells with heat-shock-GAL4, raising the temperature to $37^{\circ} \mathrm{C}$ for 30 minutes at the end of the third instar larval stage at $110.5 \mathrm{~h} \mathrm{AEL}$, then larvae were kept at $25^{\circ} \mathrm{C}$ for 9 hours, visualizing Dpn+ and PCNA-GFP at $120 \mathrm{~h}$ AEL. (A-C') Over-expression of dilp-6 resulted in Dpn+ PCNA-GFP+ cells laterally around the neuropile (B, $\mathbf{B}^{\prime}$ white arrows) and along the midline (C, $\mathbf{C}^{\prime}$ yellow arrowheads), showing that these ectopic Dpn+ cells were in S-phase. Quantification box-plots in (D), Student t-test. There were also some Dpn+ cells that were not dividing (white arrows in $C^{\prime}$ ). (E-G') Over-expression of dilp-6 resulted in PCNA-GFP+ Wrp+ midline glia (yellow arrowheads) that therefore were dividing. In (G) there is a notable increase in the number of Wrp+cells. In (E,E') lateral PCNA-GFP+Wrp-Dpn+ cells around the neuropile (white arrows) most likely correspond to neuropile glia. (H) Quantification showing phenotypic penetrance: percentage of segmentally repeated Wrp+ cell clusters that contain PCNAGFP+ cells. Fisher's Exact test $p=0.0213$. (I-L) Overexpression of ia-2 in glia with repoGAL4 mildly increased the number of $\mathrm{pH} 3+$ mitotic cells along the 
midline. The pH3+ cells lacked YFP (repoGAL4>his-YFP), consistently with corresponding to midline glia. (L) Quantification in box-plots, not significantly different from controls. One Way ANOVA $\mathrm{p}=0.0995 .(\mathbf{A}-\mathbf{C}, \mathbf{E}-\mathbf{G}, \mathbf{I}-\mathbf{K})$ horizontal views; $\left(\mathbf{A}^{\prime}-\mathbf{C}^{\prime}, \mathbf{E}^{\prime}-\mathbf{G}^{\prime}, \mathbf{I}^{\prime}-\mathbf{K}^{\prime}\right)$ transverse views. For full genotypes, sample sizes and statistical details see Table Supplement 1.

FIGURE 9 Neurons were detected from glial-derived neural stem cells. All samples were analysed at $120 \mathrm{~h}$ AEL, after disappearance of abdominal developmental neuroblasts. (A,B) prosGAL4> FlyBow can reveal expression of neural stem cells, ganglion mother cells, neurons and glia. Over-expression of dilp-6 with prosGAL4 resulted in clusters of $3 \mathrm{GFP}+$ cells along the midline, that comprised one GFP+Dpn+ neural stem cell (top row in B), a GF+Dpn-Elav- progeny cell (middle row, B) and one GFP+Elav+ progeny neuron (bottom row, B). (C,D) Progeny cells of a glial cell-lineage were visualised with GFP, expressed originally under the control of the glial repo promoter, then switched using Flipase, to the permanent actin promoter activated only in glial cells (actGAL4>y+>UASGFP/UAS-FLP; repoGAL4/Dilp-6). Over-expression of dilp-6 resulted in clusters of 2$3 \mathrm{GFP}+$ cells that comprised a GFP+Dpn+ neural stem cell and 2 progeny GFP+Elav+ neuronal progeny cells. $(\mathbf{A}, \mathbf{C})$ Horizontal and $(\mathbf{B}, \mathbf{D})$ transverse views. For full genotypes, sample sizes and statistical details see Table Supplement 1.

FIGURE 10 la-2 and Dilp-6 drive a regenerative neurogenic response to CNS injury. (A) In the abdominal larval VNC, neurons have la-2, glia have Kon, and la-2 and Kon are mutually exclusive; non-midline glia have the transcription factor Repo and midline glia the membrane protein Wrapper. In the normal, uninjured abdominal VNC, InR is in glial cells and some neurons; la-2 expression is constantly present in neurons; kon is switched off, and there are no neural stem cells (neuroblasts). (B) Drawing showing that Dilp-6 can be secreted from neurons, amplified and secreted by cortex glia, and received by all glial types. Dilp- 6 production and secretion depend on Kon and la-2, which increase in injury. (C) Injury to the abdominal VNC provokes a dramatic surge in la-2 and Kon. This 
drives the initial secretion of Dilp-6 from neurons (1). Secreted Dilp-6 binds InR in glia, and InR signaling may facilitate cleavage and activation of Kon. Kon ${ }^{\mathrm{ICD}}$ activates glial proliferation, glial cell fate gene expression and expression of dilp-6 in cortex glia (2). In an autocrine Kon and InR dependent manner, Dilp6 sets off a positive feedback loop that amplifies Dilp-6 production from cortex glia (2). Once secreted, Dilp-6 and InR signaling cause the up-regulation of Dpn+ in neuropile glia - including Notch+ Pros+ lateral (astrocytes) and Wrp+ midline glia (3). Neuropile glia can stochastically switch on Dpn. Glial-derived Dpn+ neural stem cells can divide, and generate new neurons - although to a rather limited extent (4). After cell division, Kon may determine whether daughter cells become glia, to the exclusion of la-2. (D) Insulin signalling involving la-2, Dilp-6 and InR can increase cell number of various glial cell types - including cortex glia, neuropile astrocytes and midline glia - induce neural stem cells, and potentially generate new neurons. The neurogenic potential of glia may depend on the availability of Notch and Pros, and the downregulation of Kon. Together, these genes can potentially induce neurogenesis and gliogenesis, matching cell populations for regeneration.

Figure 1 - Figure Supplement 1 Modifier genetic screens identify genes interacting with kon (A,B) Over-expression of kon in glia with repoGAL4 (repo>UASFlyBow, UASkon-full-length) caused a phenotype of very long ventral nerve cord (A), and in neurons with elavGAL4 too, although to a lesser extent (B). These phenotypes were quantified by using the reporter UASFlyBow, and the VNC measured using ImageJ tools. RNAi knock-down of candidate genes could rescue these phenotypes, some examples are shown here. (C-F) The kon gain of function (GOF) phenotype resulting from overexpressing kon-full-length in either neurons or glia, could be rescued by RNAi knock-down of: (C) predicted interactors of Kon or NG2, most prominently in glia; Kruskal Wallis ANOVA $p<0.0001$, posthoc Dunn test to $>$ FlyBow, kon controls. N=4-24 VNCs. (D) $\alpha$ and $\gamma$-secretases that cleave NG2 and Notch, from glia; Kruskal Wallis ANOVA $p<0.0001$, post-hoc Dunn test to $>$ FlyBow, kon controls. $\mathrm{N}=4$ 24 VNCs. (E) Known Kon partners, e.g. integrins, and other transmembrane proteins from neurons; 
Kruskal Wallis ANOVA $\mathrm{p}<0.0001$, post-hoc Dunn test to $>$ FlyBow, kon controls. $\mathrm{N}=3-24$ VNCs. (F)

cytoplasmic phosphatases, from either glia or neurons; Kruskal Wallis ANOVA $p<0.0001$, post-hoc

Dunn test to $>$ FlyBow, kon controls. N=7-24 VNCs. VNC length indicated in yellow in (A,B). *Asterisks

indicate multiple comparison post-hoc tests to controls: ${ }^{*} p<0.05,{ }^{* *} p<0.01,{ }^{* * *} p<0.001$,

$* * * * p<0.0001$. For full genotypes and further statistical analysis details see Table Supplement 1.

Figure 1 - Figure Supplement 2 Modifier candidate genetic screens identify genes encoding transmembrane phosphatases and insulin signaling factors as interacting with $k$ on. $(A, B)$ Over-

expression of kon in glia causes a very long VNC (A), and in neurons too, but to a lesser extent (B). RNAi knock-down of candidate genes could rescue these gain of function phenotypes, some examples are given. (C,D) Quantification of normalized VNC length shows rescue prominently by knock-down of most transmembrane phosphatases, the Notch-related Akap200, and genes functionally related to the insulin signaling pathway (Akt, lar and ia-2), most prominently lar. Normalised measurements are given as a ratio of the VNC over total larval length. Kruskal-Wallis ANOVA $p<0.0001$, post-hoc Dunn's test comparison to controls repo>kon or elav>kon. (C) $\mathrm{N}=2-28$; (D) $\mathrm{N}=2-31 .{ }^{*}$ Asterisks indicate multiple comparison post-hoc tests to controls: ${ }^{*} \mathrm{p}<0.05,{ }^{* *} \mathrm{p}<0.01$, ${ }^{* * *} p<0.001, * * * * p<0.0001$. For full genotypes and further statistical analysis details see Table Supplement 1.

Figure 1 - Figure Supplement 3 Loss and gain of kon function prominently affected ia-2 expression. (A,B) Exploratory quantitative real-time PCR ( $q R T-P C R), N=2$ replicates each: $(A)$ showing the change in mRNA levels for candidate genes upon kon RNAi targeted to either neurons (with elavGAL4) or glia (with repoGAL4). ia-2 mRNA levels increased at least 3 fold when kon was knocked-down in glia; (B) showing the effect of kon gain of function. kon over-expression in either neurons or glia decreased ia-2 mRNA levels. The first two columns have been left cut out as they are controls with the increase in kon mRNA with kon over-expression, which are very high compared to the rest. (C,D) Further 
bioRxiv preprint doi: https://doi.org/10.1101/721498; this version posted June 22, 2020. The copyright holder for this preprint (which was

not certified by peer review) is the author/funder, who has granted bioRxiv a license to display the preprint in perpetuity. It is made available under aCC-BY 4.0 International license.

replicates were carried out for a selected group of genes, and they validate that kon prominently regulates ia-2 expression. $\mathrm{N}=4$ replicates each. (D) The first columns represent the very high increase in kon mRNA with kon over-expression, and they have been cut as they go well beyond this scale compared to the rest. For full genotypes and further statistical analysis details see Table Supplement 1.

Figure 2 - Figure Supplement 1 Alterations in ia-2 levels cause no obvious neuronal phenotypes,

but can induce overgrowths. (A) Neurons and their axonal fascicles are visualised with anti-Fasll.

$\mathrm{N}=7-11$ VNCs. (B) Neurons and their dendrites are visualized with anti-BP102. N=9-10 VNCs. No abnormal phenotypes were observed. (A,B) Horizontal views; $\left(\mathbf{A}^{\prime}, \mathbf{B}^{\prime}\right)$ transverse views. (C) Anti-Dpn visualised in larvae at $120 \mathrm{~h}$ AEL, after disappearance of developmental neuroblasts. Loss of ia-2 function in neurons caused over-growths in thorax (arrowhead). N=7-12 VNCs.

Figure 5 Figure Supplement 1. Over-expressed HA-tagged Kon ${ }^{\mathrm{ICD}}$ in glia (repoGAL4>UASkon $\left.{ }^{I C d}:: H A\right)$ visualized with anti-HA antibodies in stage 16 embryos localizes to glial nuclei stained with the panglial marker anti-Repo (arrows). 


\section{Key Resources Table}

\begin{tabular}{|c|c|c|c|c|}
\hline $\begin{array}{l}\text { Reagent type } \\
\text { (species) or } \\
\text { resource }\end{array}$ & Designation & $\begin{array}{l}\text { Source or } \\
\text { reference }\end{array}$ & Identifiers & $\begin{array}{l}\text { Additional } \\
\text { information }\end{array}$ \\
\hline \multirow{25}{*}{$\begin{array}{l}\text { gene } \\
\text { (Drosophila } \\
\text { melanogaster) }\end{array}$} & kon & Flybase & FBgn0032683 & \\
\hline & IA-2 & Flybase & FBgn031294 & \\
\hline & Dilp6 & Flybase & FBgn0044047 & \\
\hline & pros & Flybase & FBgn0004595 & \\
\hline & Notch & Flybase & FBgn0004647 & \\
\hline & Ptp4E & Flybase & FBgn0004368 & \\
\hline & Ptp10D & Flybase & FBgn0004370 & \\
\hline & Ptp61F & Flybase & FBgn0267487 & \\
\hline & Ptp69D & Flybase & FBgn0014007 & \\
\hline & Ptp99A & Flybase & FBgn0004369 & \\
\hline & Hpo & Flybase & FBgn0261456 & \\
\hline & Prl-1 & Flybase & FBgn0024734 & \\
\hline & Lar & Flybase & FBgn0000464 & \\
\hline & PP2A-B' (wrd) & Flybase & FBgn0042693 & \\
\hline & Grip & Flybase & FBgn0029830 & \\
\hline & Akap200 & Flybase & FBgn0027932 & \\
\hline & arfrp1 & Flybase & FBgn0030088 & \\
\hline & CadN & Flybase & FBgn0015609 & \\
\hline & CadN2 & Flybase & FBgn0262018 & \\
\hline & Cerk & Flybase & FBgn0037315 & \\
\hline & CG42327 & Flybase & FBgn0259227 & \\
\hline & ds & Flybase & FBgn0284247 & \\
\hline & eya & Flybase & FBgn0000320 & \\
\hline & eys & Flybase & FBgn0031414 & \\
\hline & fak & Flybase & FBgn0020440 & \\
\hline
\end{tabular}


bioRxiv preprint doi: https://doi.org/10.1101/721498; this version posted June 22, 2020. The copyright holder for this preprint (which was

not certified by peer review) is the author/funder, who has granted bioRxiv a license to display the preprint in perpetuity. It is made available under aCC-BY 4.0 International license.

\begin{tabular}{|c|c|c|c|c|}
\hline & $\mathrm{ft}$ & Flybase & FBgn0001075 & \\
\hline & fu12 & Flybase & FBgn0001079 & \\
\hline & $\mathrm{fz}$ & Flybase & FBgn0001085 & \\
\hline & if & Flybase & FBgn0001250 & \\
\hline & inaD & Flybase & FBgn0001263 & \\
\hline & Kul & Flybase & FBgn0039688 & \\
\hline & kuz & Flybase & FBgn0259984 & \\
\hline & metro & Flybase & FBgn0050021 & \\
\hline & mew & Flybase & FBgn0004456 & \\
\hline & $\mathrm{mtm}$ & Flybase & FBgn0025742 & \\
\hline & mys & Flybase & FBgn0004657 & \\
\hline & sdc & Flybase & FBgn0010415 & \\
\hline & wnt5 & Flybase & FBgn0010194 & \\
\hline & wde & Flybase & FBgn0027499 & \\
\hline & vang & Flybase & FBgn0015838 & \\
\hline & stan & Flybase & FBgn0024836 & \\
\hline & Ssu72 & Flybase & FBgn0031054 & \\
\hline & shg & Flybase & FBgn0003391 & \\
\hline & psn & Flybase & FBgn0284421 & \\
\hline & probeta7 & Flybase & FBgn0250746 & \\
\hline & LanB2 & Flybase & FBgn0267348 & \\
\hline & LanA & Flybase & FBgn0002526 & \\
\hline strain, strain & $\mathrm{DH} 5 \alpha$ & $\begin{array}{l}\text { New England } \\
\text { BioLabs }\end{array}$ & C2987I & Chemically competent \\
\hline $\begin{array}{l}\text { (Escherichia } \\
\text { coli) }\end{array}$ & 10-beta & $\begin{array}{c}\text { New England } \\
\text { BioLabs }\end{array}$ & С3019I & Chemically competent \\
\hline & UAS-Kon[ICD-HA] & This paper & & \\
\hline $\begin{array}{l}\text { reagent ( } D . \\
\text { melanogaster) }\end{array}$ & $\begin{array}{l}\text { ia-2 deficiency: } \\
w^{1118} ; P\left\{w^{+}\right. \\
\} D f(2 L) E D 7733 / \\
S M 6 a\end{array}$ & $\begin{array}{l}\text { Kyoto Stock } \\
\text { Centre (DGRC) }\end{array}$ & $\begin{array}{l}\text { DGRC: } 105199 \\
\text { FLYB: FBst0313202 }\end{array}$ & \\
\hline
\end{tabular}


bioRxiv preprint doi: https://doi.org/10.1101/721498; this version posted June 22, 2020. The copyright holder for this preprint (which was

not certified by peer review) is the author/funder, who has granted bioRxiv a license to display the preprint in perpetuity. It is made available under aCC-BY 4.0 International license.

\begin{tabular}{|c|c|c|c|}
\hline UAS Flybow 1.1 & & & $\begin{array}{l}\text { Gift from I. Salecker } \\
\text { Hadjieconomou et al } \\
2011 \text { Nature Methods }\end{array}$ \\
\hline UAS-histone-YFP & Hidalgo Lab & & $\begin{array}{l}\text { Forero et al (2012) J } \\
\text { Microscopy }\end{array}$ \\
\hline kon $^{\mathrm{c452}} /$ CyO, Dfd-YFP & Hidalgo Lab & & $\begin{array}{l}\text { Losada-Perez et al } \\
2016 \text { J Cell Biology }\end{array}$ \\
\hline $\operatorname{pros}^{5044116} / T M 6 B$ & Hidalgo Lab & & $\begin{array}{l}\text { Kato et al } 2011 \text { PLoS } \\
\text { Biology }\end{array}$ \\
\hline $\operatorname{pros}^{\text {voila1 } / T M 6 B}$ & Hidalgo Lab & & $\begin{array}{l}\text { Kato et al } 2011 \text { PLoS } \\
\text { Biology }\end{array}$ \\
\hline $\begin{array}{l}\text { Notch }^{t s 1} / F M 7\left(s n^{+}\right) \\
\operatorname{actGFP}\end{array}$ & Hidalgo Lab & & $\begin{array}{l}\text { Kato et al } 2011 \text { PLoS } \\
\text { Biology }\end{array}$ \\
\hline $\begin{array}{l}\text { IA2-YFP: } w^{1118} ; \\
\text { PBac }\{566 . P . S V S-1\} \text { ia- } \\
\text { 2CPTI100013 }\end{array}$ & Kyoto DGRC & $\begin{array}{l}\text { DGRC: } 115077 \\
\text { FLYB: FBst0325075 }\end{array}$ & \\
\hline Neurons: w;;elavGal4 & Hidalgo lab & & \\
\hline $\begin{array}{l}\text { Glia: } \\
\text { w;;repoGal4/TM6B }\end{array}$ & Hidalgo Lab & & \\
\hline w Dilp-6Gal4/FM7 & & & $\begin{array}{l}\text { Gift from Alex Gould: } \\
\text { Sousa-Nunes et al } \\
2011 \text { Nature }\end{array}$ \\
\hline $\begin{array}{l}\text { W*; } \\
\text { P\{GawB\}InRNP2552 / } \\
\text { TM6B }\end{array}$ & Kyoto DGRC & $\begin{array}{l}\text { DGRC: } 104236 \\
\text { FLYB: FBst0303103 }\end{array}$ & \\
\hline $\begin{array}{l}\mathrm{w}^{*} ; \mathrm{P}\{\text { GawB }\} \text { insc } \\
{[\mathrm{Mz} 1407]}\end{array}$ & BDSC & $\begin{array}{l}\text { BDSC: } 8751 \\
\text { FLYB: FBti0148948 }\end{array}$ & \\
\hline $\begin{array}{l}\text { hs GAL4 PCNA- } \\
\text { GFP/FM7 }\end{array}$ & Hidalgo lab & & $\begin{array}{l}\text { Kato et al, } 2011 \text { PLoS } \\
\text { Biology }\end{array}$ \\
\hline $\begin{array}{l}\text { UAS-ia-2: w;; UASia-2- } \\
\text { attp2 / SM6aTM6B }\end{array}$ & this work & & $3^{\text {rd }}$ chromosome \\
\hline $\begin{array}{l}\text { UAS-ia-2: } \\
y^{1} w^{67 c 23} ; P\{G S V 6\} G S 1 \\
1438 / \text { SM1 }\end{array}$ & Kyoto DGRC & & 3nd chromosome \\
\hline$w$; UASpros-k & Hidalgo lab & & $\begin{array}{l}\text { Kato et al, } 2011 \text { PLoS } \\
\text { Biology }\end{array}$ \\
\hline $\begin{array}{l}\text { w; UAS-HA-Kon FL4- } \\
\text { 1/TM3 Twi-GFP }\end{array}$ & Hidalgo lab & & $\begin{array}{l}\text { Losada-Perez et al } \\
2016 \text { J Cell Biology }\end{array}$ \\
\hline w; UAShistone-YFP & Hidalgo lab & & $\begin{array}{l}\text { Kato et al, } 2011 \text { PLoS } \\
\text { Biology }\end{array}$ \\
\hline
\end{tabular}


bioRxiv preprint doi: https://doi.org/10.1101/721498; this version posted June 22,2020 . The copyright holder for this preprint (which was

not certified by peer review) is the author/funder, who has granted bioRxiv a license to display the preprint in perpetuity. It is made available under aCC-BY 4.0 International license.

\begin{tabular}{|c|c|c|c|}
\hline$y^{1} w^{1118} ; ;$ UAS-dilp-6 & & & $\begin{array}{l}\text { Gift from Alex Gould: } \\
\text { Sousa-Nunes et al } \\
2011 \text { Nature }\end{array}$ \\
\hline $\begin{array}{l}y^{1} w^{1118} ; P\{\text { UAS- } \\
\text { InR.K1409A } 2\end{array}$ & BDSC & $\begin{array}{l}\text { BDSC: } 8252 \\
\text { FLYB: FBti0040688 }\end{array}$ & \\
\hline $\begin{array}{l}\text { G-TRACE: } w\left[{ }^{*}\right] \\
\text { P }\{w[+m C]=U A S- \\
\text { RedStinger }\} 4, \\
\text { P\{w[+mC }]=U A S- \\
\text { FLP.D }\} \text { JD } 1, \\
\text { P\{w[+mC]=Ubi- } \\
\text { p63E(FRT.STOP)Stinger } \\
\text { \}9F6/CyO }\end{array}$ & BDSC & $\begin{array}{l}\text { BDSC: } 28280 \\
\text { FLYB: FBst0028280 }\end{array}$ & \\
\hline $\begin{array}{l}\text { UAS-ia-2-RNAi: } \\
\text { y }^{1} \mathrm{SC}^{1} v^{1} ; ; \mathrm{P}\{\text { TRIP } \\
\text { HMSO0536\} attP2 }\end{array}$ & BDSC & $\begin{array}{l}\text { BDSC:33672 } \\
\text { FLYB: BDSC:38369 } \\
\text { FLYB: FBti0149584 }\end{array}$ & \\
\hline $\begin{array}{l}\text { UAS-ia-2-RNAi: } \\
\text { P\{KK108555\}VIE-260B }\end{array}$ & VDRC & $\begin{array}{l}\text { VDRC:110595 } \\
\text { FLYB:FBti0142260 }\end{array}$ & \\
\hline $\begin{array}{l}\text { UAS-konRNAi } \\
\text { :P\{KK102101\}VIE- } \\
260 B\end{array}$ & VDRC & $\begin{array}{l}\text { VDRC:106680 } \\
\text { FLYB:FBti0117275 }\end{array}$ & \\
\hline $\begin{array}{l}\text { UAS-Dilp6-RNAi: } \\
\text { P\{KK111727\}VIE-260B }\end{array}$ & VDRC & $\begin{array}{l}\text { VDRC:102465 } \\
\text { FLYB:FBti0123146 }\end{array}$ & \\
\hline $\begin{array}{l}\text { UAS-ptp4E RNAi: } \\
\text { yscv;;P\{TripHMSO183 } \\
\text { 8\}attp2 }\end{array}$ & BDSC & $\begin{array}{l}\text { BDSC:38369 } \\
\text { FLYB: FBti0149584 }\end{array}$ & \\
\hline $\begin{array}{l}\text { UAS-ptp10D RNAi: } \\
\text { yscv;;P\{TripHMSO191 } \\
\text { 7\}attp2 }\end{array}$ & BDSC & $\begin{array}{l}\text { BDSC:38369 } \\
\text { FLYB: FBti0149662 }\end{array}$ & \\
\hline $\begin{array}{l}\text { UAS-ptp61F RNAi: } \\
\text { yscv;;P\{TripHMCO434 } \\
\text { 46\}attp2 }\end{array}$ & BDSC & $\begin{array}{l}\text { BDSC: } 56036 \\
\text { FLYB: FBti0163438 }\end{array}$ & \\
\hline $\begin{array}{l}\text { UAS-ptp69A RNAi: } \\
\text { yv;;P\{TripJFO3399\}att } \\
\text { p2 }\end{array}$ & BDSC & $\begin{array}{l}\text { BDSC: } 29462 \\
\text { FLYB: FBti0129090 }\end{array}$ & \\
\hline $\begin{array}{l}\text { UAS-ptp99A RNA: } \\
\text { yv;;p\{TripJF01858\}att } \\
\text { p2 }\end{array}$ & BDSC & $\begin{array}{l}\text { BDSC: } 25840 \\
\text { FLYB: FBti0114591 }\end{array}$ & \\
\hline $\begin{array}{l}\text { UAS-Hpo RNAi: } \\
\text { yv;;p\{TripHMSO0006\} } \\
\text { attp2 }\end{array}$ & BDSC & $\begin{array}{l}\text { BDSC: } 33614 \\
\text { FLYB: FBti0140087 }\end{array}$ & \\
\hline $\begin{array}{l}\text { UAS-Prl-1 RNAi: } \\
\text { yscvp;;\{TripPMAS018 } \\
\text { 26\}attp2/TM3,Sb }\end{array}$ & BDSC & $\begin{array}{l}\text { BDSC:38358 } \\
\text { FLYB: FBti0149572 }\end{array}$ & \\
\hline
\end{tabular}


bioRxiv preprint doi: https://doi.org/10.1101/721498; this version posted June 22, 2020. The copyright holder for this preprint (which was

not certified by peer review) is the author/funder, who has granted bioRxiv a license to display the preprint in perpetuity. It is made available under aCC-BY 4.0 International license.

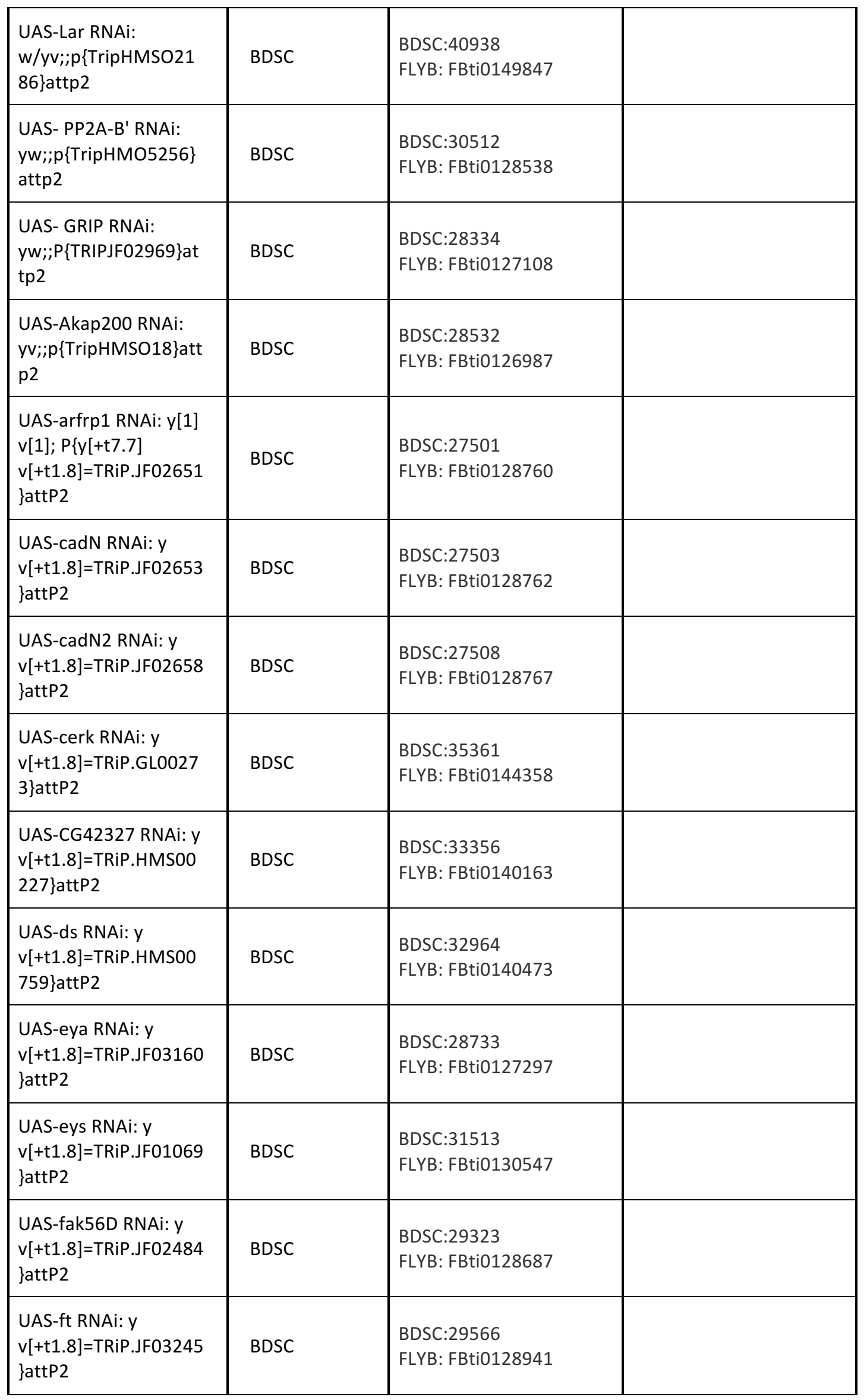


bioRxiv preprint doi: https://doi.org/10.1101/721498; this version posted June 22, 2020. The copyright holder for this preprint (which was

not certified by peer review) is the author/funder, who has granted bioRxiv a license to display the preprint in perpetuity. It is made available under aCC-BY 4.0 International license.

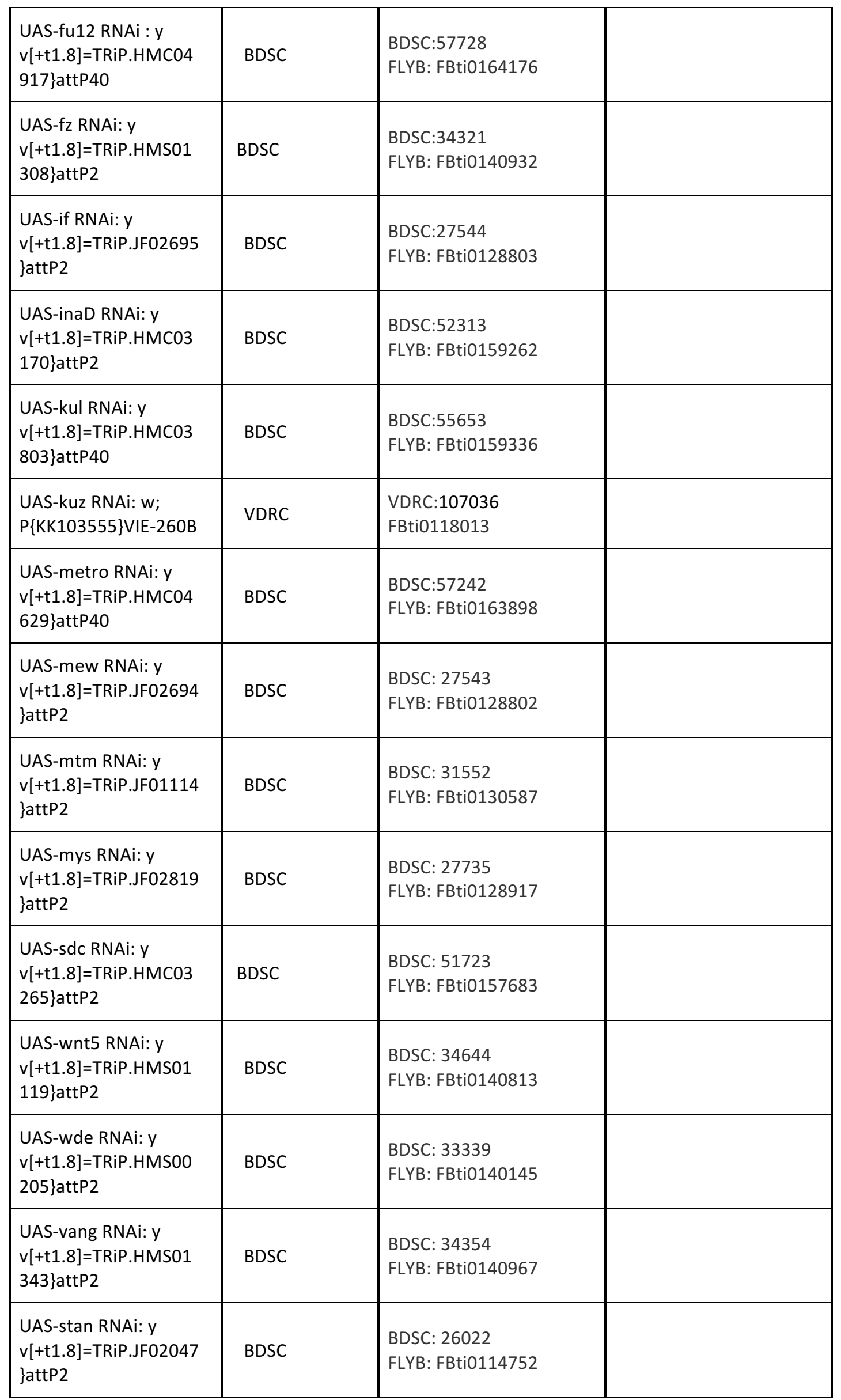


bioRxiv preprint doi: https://doi.org/10.1101/721498; this version posted June 22, 2020. The copyright holder for this preprint (which was

not certified by peer review) is the author/funder, who has granted bioRxiv a license to display the preprint in perpetuity. It is made available under aCC-BY 4.0 International license.

\begin{tabular}{|c|c|c|c|c|}
\hline & $\begin{array}{l}\text { UAS-ssu72 RNAi: y } \\
\text { v[+t1.8]=TRiP.HMSO4 } \\
\text { 461\}attP40 }\end{array}$ & BDSC & $\begin{array}{l}\text { BDSC: } 57018 \\
\text { FLYB: FBti0164838 }\end{array}$ & \\
\hline & $\begin{array}{l}\text { UAS-shg RNAi: y } \\
\text { v;;TRiP.JF02769\}attP2 } \\
\text { /TM3, Sb[1] }\end{array}$ & BDSC & $\begin{array}{l}\text { BDSC: } 27689 \\
\text { FLYB: FBti0128871 }\end{array}$ & \\
\hline & $\begin{array}{l}\text { UAS-psn RNAi: y v;; } \\
\text { TRiP.JF02760\}attP2/T } \\
\text { M3, Sb[1] }\end{array}$ & BDSC & $\begin{array}{l}\text { BDSC: } 27681 \\
\text { FLYB: FBti0128862 }\end{array}$ & \\
\hline & $\begin{array}{l}\text { UAS-prosbeta7 RNAi: } \\
\text { y } \\
\text { v[+t1.8];;TRiP.HMSOO } \\
\text { 122\}attP2 }\end{array}$ & BDSC & $\begin{array}{l}\text { BDSC: } 34812 \\
\text { FLYB: FBti0146659 }\end{array}$ & \\
\hline & $\begin{array}{l}\text { UAS-prl-1 RNAi: y v } \\
\text { TRiP.HMS01826\}attP2 } \\
\text { /TM3, Sb[1] }\end{array}$ & BDSC & $\begin{array}{l}\text { BDSC: } 38358 \\
\text { FLYB: FBti0149572 }\end{array}$ & \\
\hline & $\begin{array}{l}\text { UAS-lar RNAi : y } \\
\text { v[+t1.8]=TRiP.HMSO2 } \\
\text { 186\}attP40 }\end{array}$ & $\mathrm{BDSC}$ & $\begin{array}{l}\text { BDSC: } 40938 \\
\text { FLYB: FBti0149847 }\end{array}$ & \\
\hline & $\begin{array}{l}\text { UAS-lanB2 RNAi: y } \\
\text { v[+t1.8]=TRiP.HMC04 } \\
\text { 076\}attP40 }\end{array}$ & BDSC & $\begin{array}{l}\text { BDSC: } 55388 \\
\text { FLYB: FBti0159607 }\end{array}$ & \\
\hline & $\begin{array}{l}\text { UAS-lanA RNAi: y } \\
\text { v[+t1.8]=TRiP.JF02908 } \\
\text { \}attP2 }\end{array}$ & BDSC & $\begin{array}{l}\text { BDSC: } 28071 \\
\text { FLYB: FBti0128057 }\end{array}$ & \\
\hline \multirow{7}{*}{ antibody } & $\begin{array}{l}\text { Anti-GFP (Rabbit } \\
\text { polyclonal) }\end{array}$ & $\begin{array}{l}\text { Molecular } \\
\text { Probes }\end{array}$ & Cat\# A-11122 & IF $(1: 250)$ \\
\hline & $\begin{array}{l}\text { Anti-Repo (guinea pig } \\
\text { monoclonal) }\end{array}$ & $\begin{array}{l}\text { Gift from } \\
\text { B. Altenhein }\end{array}$ & & IF $(1: 1000)$ \\
\hline & $\begin{array}{l}\text { Anti-Repo (Mouse } \\
\text { monoclonal) }\end{array}$ & DSHB, lowa & $\begin{array}{l}\text { Cat\# 8D12 } \\
\text { RRID:AB_528448 }\end{array}$ & IF $(1: 100)$ \\
\hline & $\begin{array}{l}\text { Anti-HA CF9F4 } \\
\text { (Rabbit polyclonal) }\end{array}$ & Cell signaling & Cat.-No. 3724 & IF (1:1600) \\
\hline & Anti-Dpn (Guinea pig) & $\begin{array}{l}\text { Gift from } \\
\text { J. Jan }\end{array}$ & & IF $(1: 500-1: 1000)$ \\
\hline & $\begin{array}{l}\text { Anti-Prospero (mouse } \\
\text { monoclonal) }\end{array}$ & DSHB & $\begin{array}{l}\text { Cat\# MR1A } \\
\text { RRID: AB_528440 }\end{array}$ & IF $(1: 250)$ \\
\hline & $\begin{array}{l}\text { Anti-Elav (Rat } \\
\text { monoclonal) }\end{array}$ & DSHB & $\begin{array}{l}\text { Cat\# 7E8A10 } \\
\text { RRID: AB_528218 }\end{array}$ & IF $(1: 250)$ \\
\hline
\end{tabular}


bioRxiv preprint doi: https://doi.org/10.1101/721498; this version posted June 22, 2020. The copyright holder for this preprint (which was

not certified by peer review) is the author/funder, who has granted bioRxiv a license to display the preprint in perpetuity. It is made available under aCC-BY 4.0 International license.

\begin{tabular}{|c|c|c|c|}
\hline $\begin{array}{l}\text { Anti-Eve } 3 C 10 \text { (mouse } \\
\text { monoclonal) }\end{array}$ & DSHB & $\begin{array}{l}\text { Cat\# 3C10 } \\
\text { RRID: AB_528229 }\end{array}$ & IF $\{1: 20)$ \\
\hline $\begin{array}{l}\text { Anti-Wrapper (mouse } \\
\text { monoclonal) }\end{array}$ & DSHB & $\begin{array}{l}\text { Cat\# 10D3 } \\
\text { RRID: AB_528514 }\end{array}$ & IF (1:5) \\
\hline $\begin{array}{l}\text { Anti-Phospho- } \\
\text { histone-H3 (rabbit) }\end{array}$ & $\begin{array}{l}\text { Upstate } \\
\text { Biotechnology }\end{array}$ & Cat\#06-570 & IF (1:250) \\
\hline $\begin{array}{l}\text { Anti-Rabbit } 488 \text { Alexa } \\
\text { Fluor (Donkey } \\
\text { polyclonal) }\end{array}$ & $\begin{array}{l}\text { Molecular } \\
\text { Probes } \\
\text { Invitrogen }\end{array}$ & $\begin{array}{l}\text { Cat\# A-21206 } \\
\text { RRID:AB_2535792 }\end{array}$ & IF $(1: 250)$ \\
\hline $\begin{array}{l}\text { Anti-Rabbit } 488 \text { Alexa } \\
\text { Fluor (Goat) }\end{array}$ & $\begin{array}{l}\text { Molecular } \\
\text { Probes } \\
\text { Invitrogen }\end{array}$ & $\begin{array}{l}\text { Cat\# A11034 } \\
\text { RRID: AB_2576217 }\end{array}$ & IF $(1: 250)$ \\
\hline $\begin{array}{l}\text { Anti-Rabbit } 647 \text { Alexa } \\
\text { Fluor (Goat) }\end{array}$ & $\begin{array}{l}\text { Molecular } \\
\text { Probes } \\
\text { Invitrogen }\end{array}$ & $\begin{array}{l}\text { Cat\# A21245 } \\
\text { RRID: AB_2535813 }\end{array}$ & IF $(1: 250)$ \\
\hline $\begin{array}{l}\text { Anti-Guinea Pig } 488 \\
\text { Alexa Fluor (Goat } \\
\text { polyclonal) }\end{array}$ & $\begin{array}{l}\text { Molecular } \\
\text { Probes } \\
\text { Invitrogen }\end{array}$ & $\begin{array}{l}\text { Cat\# A11073 } \\
\text { RRID: AB_2534117 }\end{array}$ & IF $(1: 250)$ \\
\hline $\begin{array}{l}\text { Anti-Guinea Pig } 546 \\
\text { Alexa Fluor (Goat } \\
\text { polyclonal) }\end{array}$ & $\begin{array}{l}\text { Molecular } \\
\text { Probes } \\
\text { Invitrogen }\end{array}$ & $\begin{array}{l}\text { Cat\# A11074 } \\
\text { RRID: AB_2534118 }\end{array}$ & IF $(1: 250)$ \\
\hline $\begin{array}{l}\text { Anti-Guinea Pig } 633 \\
\text { Alexa Fluor (Goat } \\
\text { polyclonal) }\end{array}$ & $\begin{array}{l}\text { Molecular } \\
\text { Probes } \\
\text { Invitrogen }\end{array}$ & $\begin{array}{l}\text { Cat\# A-21105 } \\
\text { RRID: AB_2535757 }\end{array}$ & IF $(1: 250)$ \\
\hline $\begin{array}{l}\text { Anti-Rat } 546 \text { Alexa } \\
\text { Fluor (Goat } \\
\text { polyclonal) }\end{array}$ & $\begin{array}{l}\text { Molecular } \\
\text { Probes } \\
\text { Invitrogen }\end{array}$ & $\begin{array}{l}\text { Cat\# A11081 } \\
\text { RRID: AB_2534125 }\end{array}$ & IF $(1: 250)$ \\
\hline $\begin{array}{l}\text { Anti-Rat } 647 \text { Alexa } \\
\text { Fluor (Goat } \\
\text { polyclonal) }\end{array}$ & $\begin{array}{l}\text { Molecular } \\
\text { Probes } \\
\text { Invitrogen }\end{array}$ & $\begin{array}{l}\text { Cat\# A-21247 } \\
\text { RRID: AB_141778 }\end{array}$ & IF $(1: 250)$ \\
\hline $\begin{array}{l}\text { Anti-Rat } 660 \text { Alexa } \\
\text { Fluor (Goat } \\
\text { polyclonal) }\end{array}$ & $\begin{array}{l}\text { Molecular } \\
\text { Probes } \\
\text { Invitrogen }\end{array}$ & $\begin{array}{l}\text { Cat\# A21095 } \\
\text { RRID: }\end{array}$ & IF $(1: 250)$ \\
\hline $\begin{array}{l}\text { Anti-Mouse } 488 \\
\text { Alexa Fluor (Goat } \\
\text { polyclonal) }\end{array}$ & $\begin{array}{l}\text { Molecular } \\
\text { Probes } \\
\text { Invitrogen }\end{array}$ & $\begin{array}{l}\text { Cat\# A11029 } \\
\text { RRID: AB_2534088 }\end{array}$ & IF $(1: 250)$ \\
\hline $\begin{array}{l}\text { Anti-Mouse } 546 \\
\text { Alexa Fluor (Goat } \\
\text { polyclonal) }\end{array}$ & $\begin{array}{l}\text { Molecular } \\
\text { Probes } \\
\text { Invitrogen }\end{array}$ & $\begin{array}{l}\text { Cat\# } \\
\text { RRID: }\end{array}$ & IF $(1: 250)$ \\
\hline
\end{tabular}


bioRxiv preprint doi: https://doi.org/10.1101/721498; this version posted June 22,2020 . The copyright holder for this preprint (which was

not certified by peer review) is the author/funder, who has granted bioRxiv a license to display the preprint in perpetuity. It is made available under aCC-BY 4.0 International license.

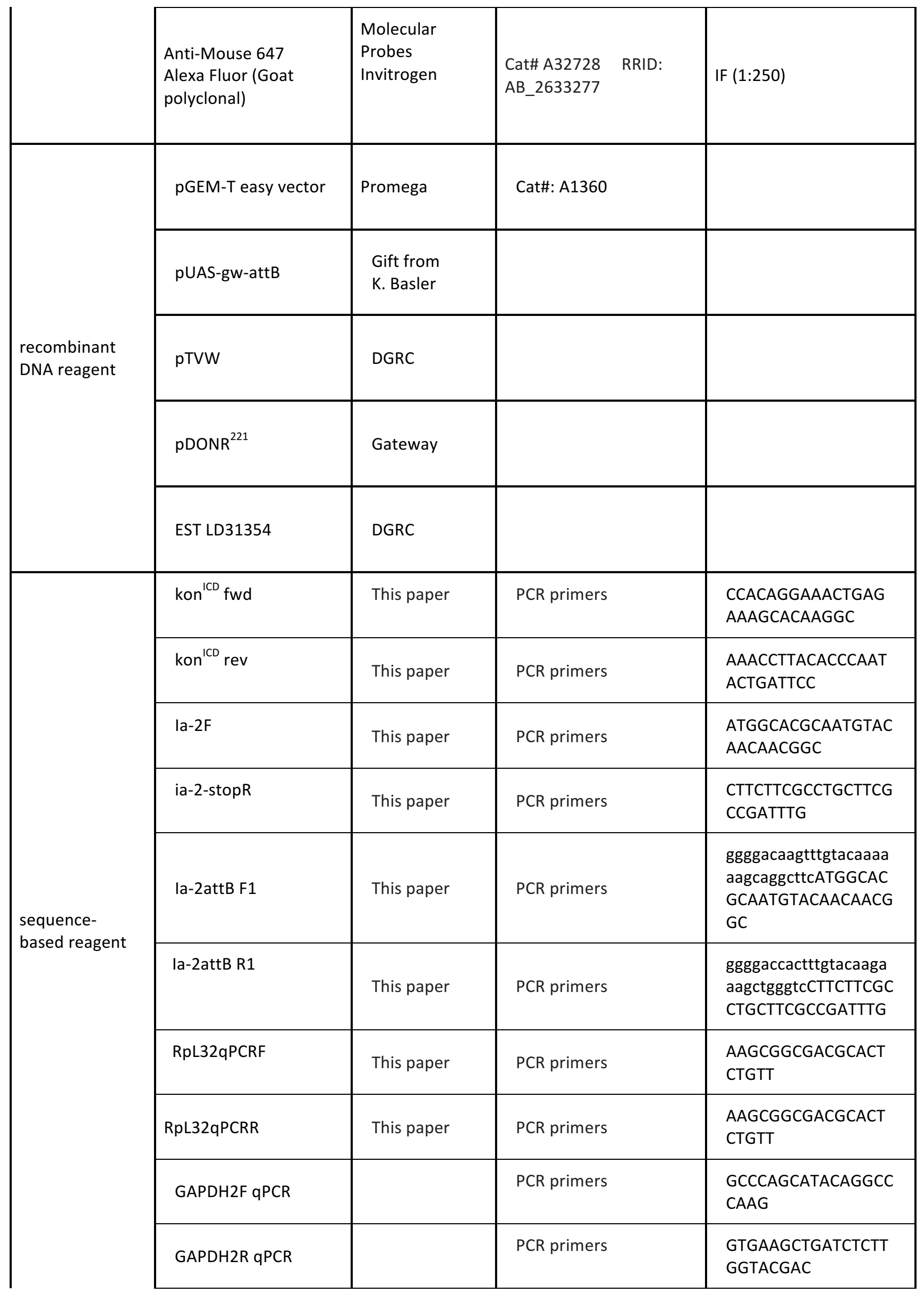


bioRxiv preprint doi: https://doi.org/10.1101/721498; this version posted June 22, 2020. The copyright holder for this preprint (which was

not certified by peer review) is the author/funder, who has granted bioRxiv a license to display the preprint in perpetuity. It is made available under aCC-BY 4.0 International license.

\begin{tabular}{|c|c|c|}
\hline $\begin{array}{l}\text { KonqPCR(Ex10-11) } \\
\text { F3 }\end{array}$ & PCR primers & $\begin{array}{l}\text { CCGCGCCCTAATCTTT } \\
\text { AАCTTTTAC }\end{array}$ \\
\hline $\begin{array}{l}\text { KonqPCR(Ex10-11) } \\
\text { R3 }\end{array}$ & PCR primers & $\begin{array}{l}\text { CCCAAGCGATTTCTTT } \\
\text { ACCA }\end{array}$ \\
\hline ptp99A qPCR F2 & PCR primers & $\begin{array}{l}\text { TCGCTATCCCAACATC } \\
\text { ACGG }\end{array}$ \\
\hline ptp99A qPCR R2 & PCR primers & $\begin{array}{l}\text { TGAACGCATGTCCCTT } \\
\text { CTGG }\end{array}$ \\
\hline Fz qPCR F1 & PCR primers & $\begin{array}{l}\text { AGTCGCACTTATTCCA } \\
\text { CCTGG }\end{array}$ \\
\hline Fz qPCR R1 & PCR primers & $\begin{array}{l}\text { CTGGCCCACGAAACAA } \\
\text { ACG }\end{array}$ \\
\hline Hippo qPCR F2 & PCR primers & $\begin{array}{l}\text { ACCCATAGCCACAGAG } \\
\text { TATTCT }\end{array}$ \\
\hline Hippo qPCR R2 & PCR primers & $\begin{array}{l}\text { TGCTGTTCATCCTGCT } \\
\text { GTTG }\end{array}$ \\
\hline ia-2 qPCR F1 & PCR primers & $\begin{array}{l}\text { ACGGTCACCCAGTTTC } \\
\text { ACTT }\end{array}$ \\
\hline ia-2 qPCR R1 & PCR primers & $\begin{array}{l}\text { CGGTAGGACTTGTTCA } \\
\text { CTTTCC }\end{array}$ \\
\hline InaD qPCR F1 & PCR primers & $\begin{array}{l}\text { TCATTGAGTTGAAGGT } \\
\text { GGAAAAGA }\end{array}$ \\
\hline InaD qPCR R1 & PCR primers & $\begin{array}{l}\text { CTGCCACTTGTCCCTCC } \\
\text { G }\end{array}$ \\
\hline lar qPCR F1 & PCR primers & $\begin{array}{l}\text { TTGCTGAGTACAACAT } \\
\text { GCCG }\end{array}$ \\
\hline lar qPCR R1 & PCR primers & $\begin{array}{l}\text { TGAAGTCGATGAAGCC } \\
\text { CTCG }\end{array}$ \\
\hline Prl-1 qPCR F1 & PCR primers & $\begin{array}{l}\text { TGACGAGTGGTTTGAG } \\
\text { GTCTTAA }\end{array}$ \\
\hline Prl-1 qPCR R1 & PCR primers & $\begin{array}{l}\text { GCCCAATTCAATCAGT } \\
\text { GCCA }\end{array}$ \\
\hline Ptp10D qPCR F1 & PCR primers & $\begin{array}{l}\text { TGCAACAGATCAACAC } \\
\text { GTCTG }\end{array}$ \\
\hline Ptp10D qPCR R1 & PCR primers & $\begin{array}{l}\text { TATACTGCTGCTCCGT } \\
\text { CTGC }\end{array}$ \\
\hline Ptp61F qPCR F1 & PCR primers & $\begin{array}{l}\text { GTCCAAGGTGCTCTGC } \\
\text { GAG }\end{array}$ \\
\hline
\end{tabular}


bioRxiv preprint doi: https://doi.org/10.1101/721498; this version posted June 22,2020 . The copyright holder for this preprint (which was

not certified by peer review) is the author/funder, who has granted bioRxiv a license to display the preprint in perpetuity. It is made available under aCC-BY 4.0 International license.

\begin{tabular}{|c|c|c|c|c|}
\hline & Ptp61F qPCR R1 & & PCR primers & $\begin{array}{l}\text { ATGAGGGGTTCTTCAG } \\
\text { CGTC }\end{array}$ \\
\hline & Ptp69D qPCR F1 & & PCR primers & $\begin{array}{l}\text { TGTAGTGTGGGCGAA } \\
\text { AACGA }\end{array}$ \\
\hline & Ptp69D qPCR R1 & & PCR primers & $\begin{array}{l}\text { CGCATCGGAAGTGGT } \\
\text { GTTAG }\end{array}$ \\
\hline & Yorkie qPCR F1 & & PCR primers & $\begin{array}{l}\text { ATCAGCCCCATTCAGT } \\
\text { TGAAC }\end{array}$ \\
\hline & Yorkie qPCR R1 & & PCR primers & $\begin{array}{l}\text { CCTCCCACTGCGTAGA } \\
\text { TTTTGTA }\end{array}$ \\
\hline & Dpn qPCR F1 & & PCR primers & $\begin{array}{l}\text { ACGCATGTCCAATCCC } \\
\text { AATG }\end{array}$ \\
\hline & Dpn qPCR R2 & & PCR primers & $\begin{array}{l}\text { GCGACGTTTCTCCATA } \\
\text { ATCGGT }\end{array}$ \\
\hline & Elav qPCR F1 & & PCR primers & $\begin{array}{l}\text { CTACTTGCCGCAAACA } \\
\text { ATGAC }\end{array}$ \\
\hline & Elav qPCR R1 & & PCR primers & $\begin{array}{l}\text { CTTCACCGACTCAATCT } \\
\text { CGC }\end{array}$ \\
\hline & dilp6 qPCR F1 & & PCR primers & $\begin{array}{l}\text { CGATGTATTTCCCAAC } \\
\text { AGTTTCG }\end{array}$ \\
\hline & dilp6 qPCR R1 & & PCR primers & $\begin{array}{l}\text { AAATCGGTTACGTTCT } \\
\text { GCAAGTC }\end{array}$ \\
\hline \multirow{5}{*}{$\begin{array}{l}\text { commercial } \\
\text { assay or kit }\end{array}$} & $\begin{array}{l}\text { Gateway BP Clonase II } \\
\text { Enzyme Mix }\end{array}$ & Invitrogen & Cat\#: 11789020 & \\
\hline & $\begin{array}{l}\text { Gateway LR Clonase II } \\
\text { Enzyme Mix }\end{array}$ & Invitrogen & Cat\#: 11791020 & \\
\hline & $\begin{array}{l}\text { QIAquick Gel Extraction } \\
\text { Kit }\end{array}$ & Qiagen & Cat No./ID: 28704 & \\
\hline & $\begin{array}{l}\text { QIAGEN Plasmid Midi } \\
\text { Kit }\end{array}$ & Qiagen & Cat No./ID: 12143 & \\
\hline & SensiFAST SYBR Hi-ROX & Bioline & Cat\#: BIO-92020 & \\
\hline $\begin{array}{l}\text { software, } \\
\text { algorithm }\end{array}$ & GraphPad Prism 6 & GraphPad & & \\
\hline $\begin{array}{l}\text { software, } \\
\text { algorithm }\end{array}$ & DNASTAR Lasergene & DNASTAR & & \\
\hline
\end{tabular}


bioRxiv preprint doi: https://doi.org/10.1101/721498; this version posted June 22, 2020. The copyright holder for this preprint (which was not certified by peer review) is the author/funder, who has granted bioRxiv a license to display the preprint in perpetuity. It is made available under aCC-BY 4.0 International license.

\begin{tabular}{|l|l|l|l|l|}
\hline $\begin{array}{l}\text { software, } \\
\text { algorithm }\end{array}$ & DeadEasy Larval Glia & Hidalgo Lab & ImageJ Plugin & $\begin{array}{l}\text { Forero et al 2012 J } \\
\text { Microscopy }\end{array}$ \\
\hline $\begin{array}{l}\text { software, } \\
\text { algorithm }\end{array}$ & Adobe Illustrator & Adobe CS6 & & \\
\hline $\begin{array}{l}\text { software, } \\
\text { algorithm }\end{array}$ & Adobe Photoshop & Adobe CS6 & & \\
\hline $\begin{array}{l}\text { software, } \\
\text { algorithm }\end{array}$ & ImageJ, Fiji & $\begin{array}{l}\text { ej.nih.gov/ij/ } \\
\text { download.ht } \\
\text { ml }\end{array}$ & & \\
\hline
\end{tabular}


Figure 1 - Figure Supplement 1 Modifier genetic screens identify genes interacting with kon

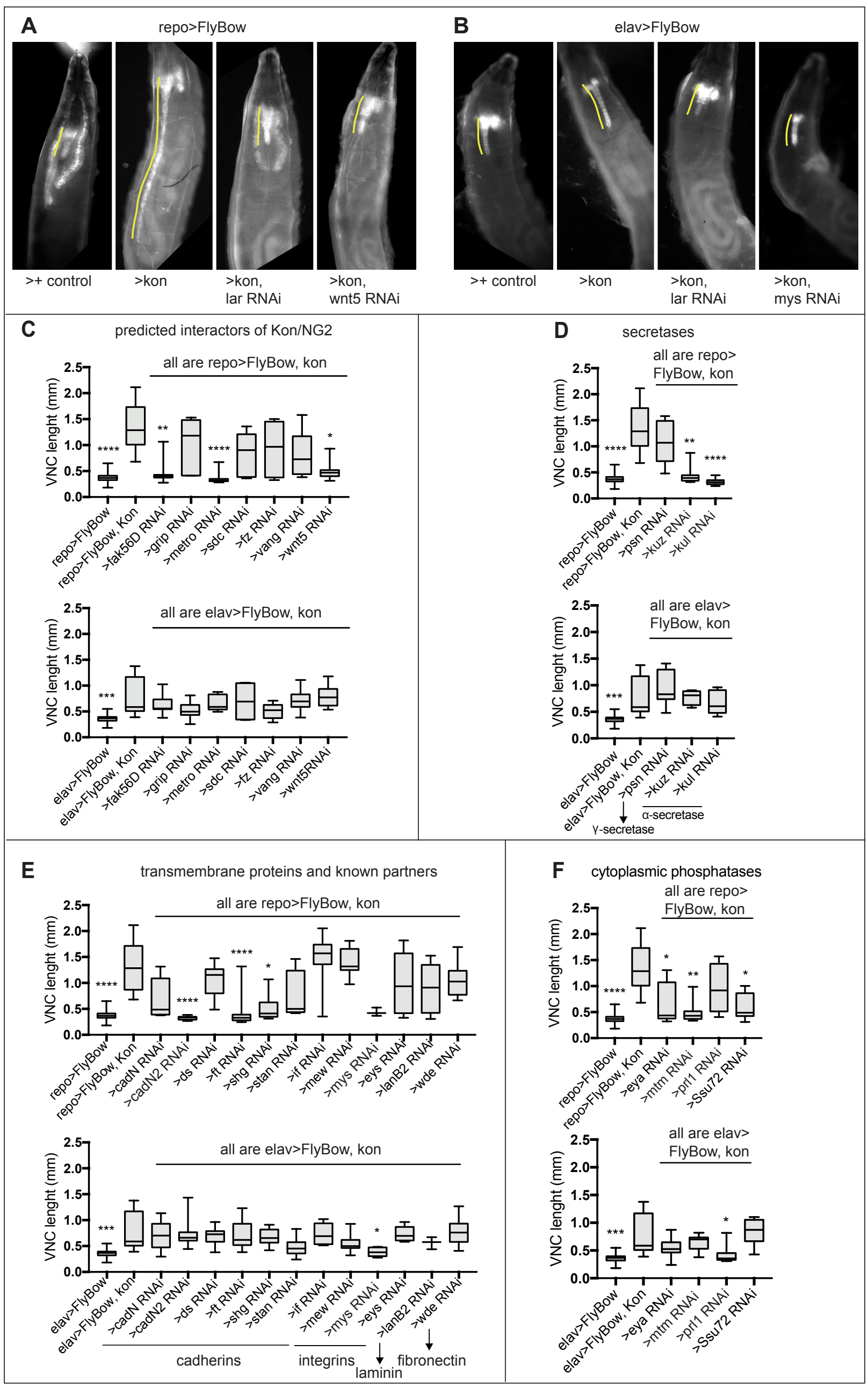


bioRxiv preprint doi: https://doi.org/10.1101/721498; this version posted June 22, 2020. The copyright holder for this preprint (which was

not certified by peer review) is the author/funder, who has granted bioRxiv a license to display the preprint in perpetuity. It is made available under aCC-BY 4.0 International license.

Figure 1 - Figure Supplement 2

Modifier candidate genetic screens identify genes encoding transmembrane phosphatases and insulin signaling factors as interacting with kon.

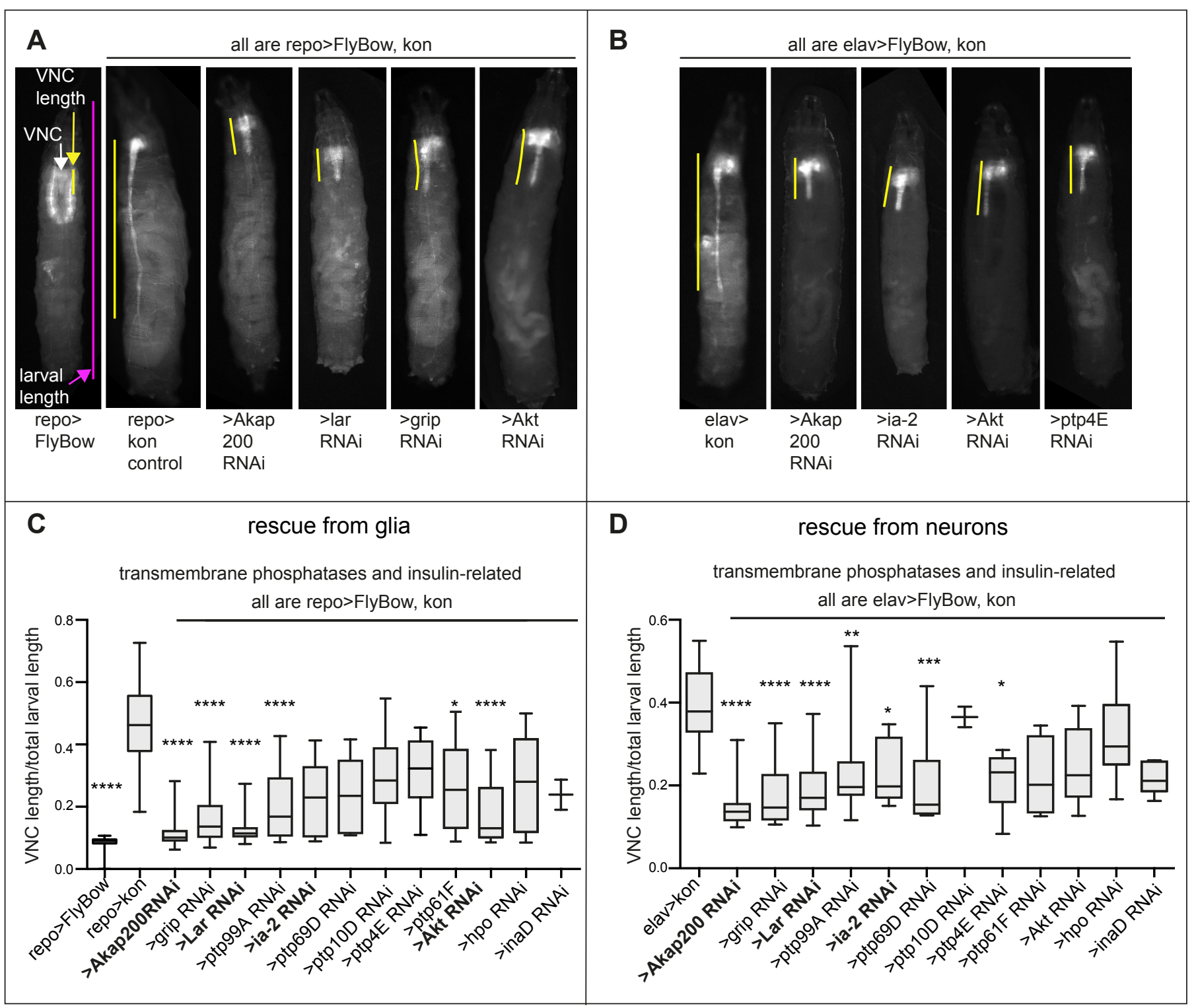


bioRxiv preprint doi: https://doi.org/10.1101/721498; this version posted June 22, 2020. The copyright holder for this preprint (which was

not certified by peer review) is the author/funder, who has granted bioRxiv a license to display the preprint in perpetuity. It is made available under aCC-BY 4.0 International license.

A qRT-PCR: effect of kon RNAi knock-down

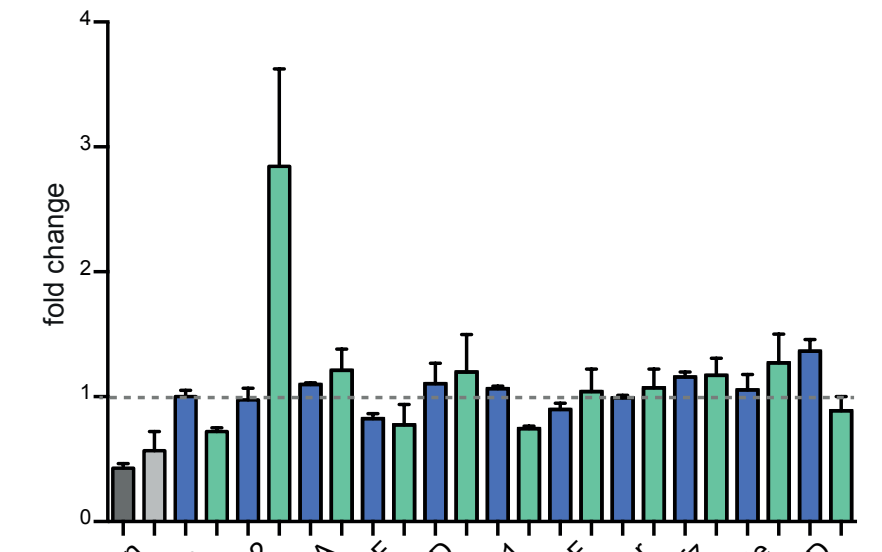

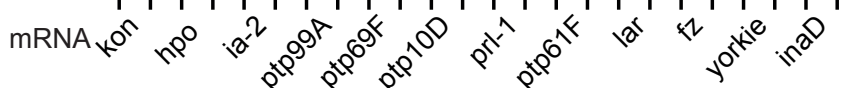

control kon mRNA:

$\square$ kon $^{\text {c452 }}$ elav>kon-RNAi

$\square$ kon $^{\mathrm{c}}{ }^{452}$ repo>kon-RNAi

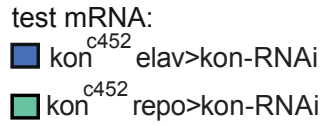

C

qRT-PCR: effect of kon RNAi knock-down

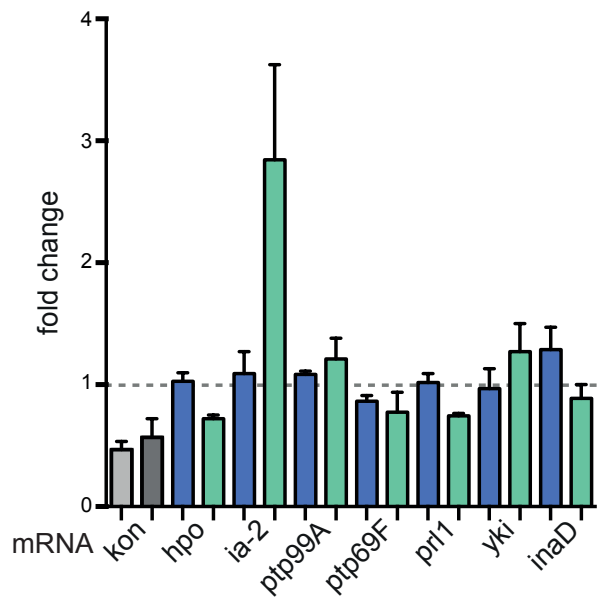

B

qRT-PCR: effect of kon over-expression

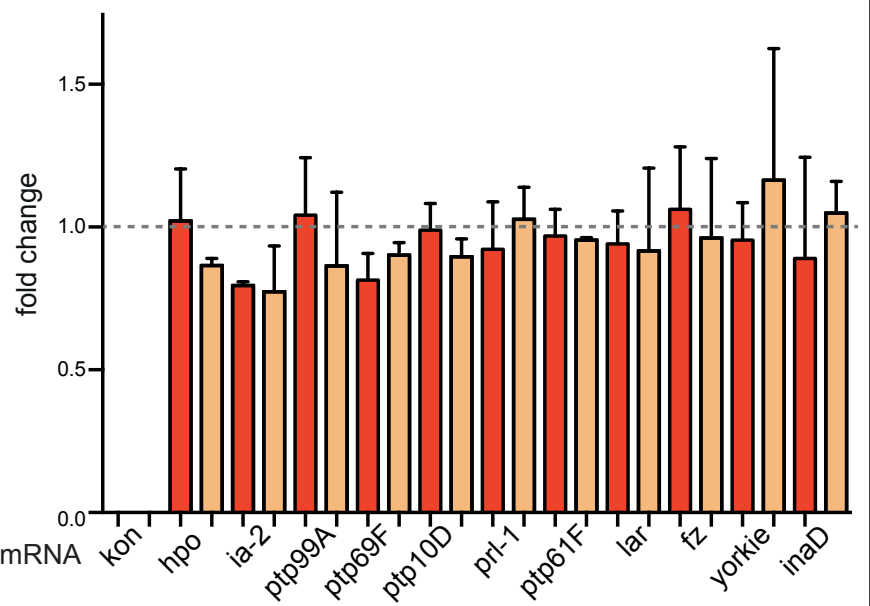

control kon mRNA:

test mRNA:

$\square$ elav>Kon

$\square$ elav>Kon

$\square$ repo>Kon

$\square$ repo>Kon
D $\quad$ qRT-PCR: effect of kon over-expression

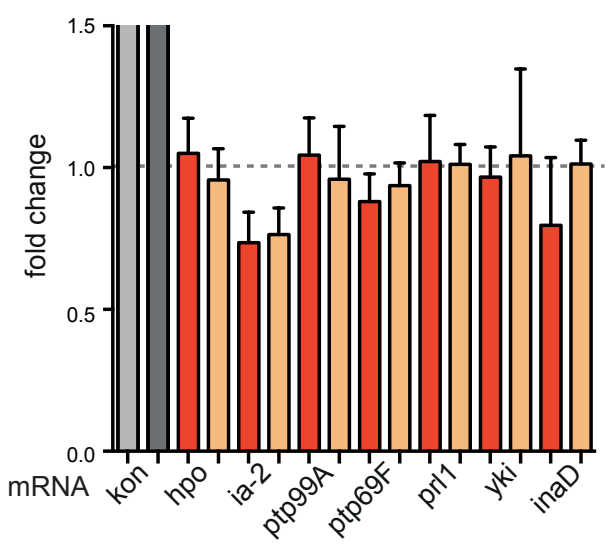


bioRxiv preprint doi: https://doi.org/10.1101/721498; this version posted June 22, 2020. The copyright holder for this preprint (which was

not certified by peer review) is the author/funder, who has granted bioRxiv a license to display the preprint in perpetuity. It is made available under aCC-BY 4.0 International license.

Figure 1 ia-2 interacts genetically with kon, Notch and pros

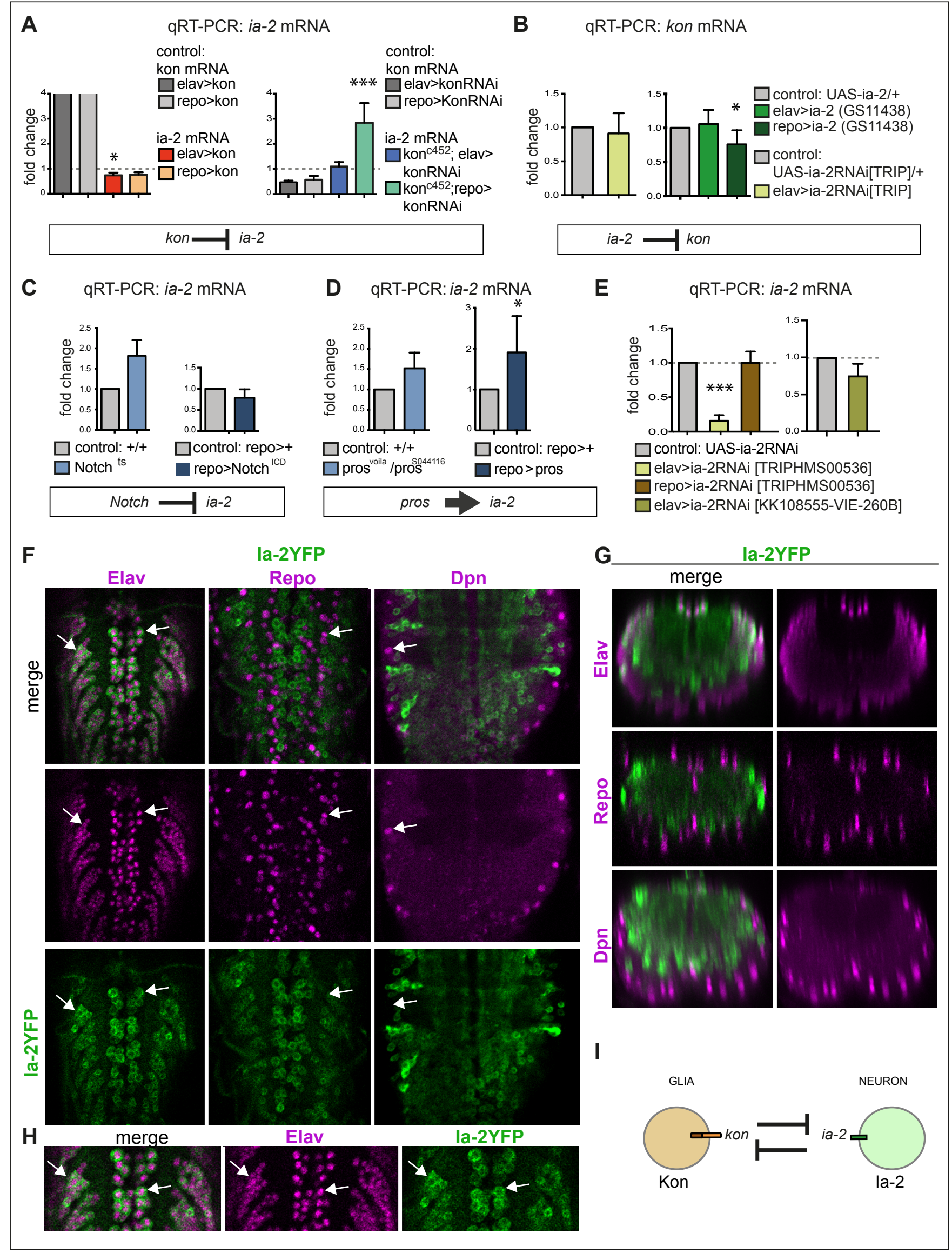


bioRxiv preprint doi: https://doi.org/10.1101/721498; this version posted June 22, 2020. The copyright holder for this preprint (which was not certified by peer review) is the author/funder, who has granted bioRxiv a license to display the preprint in perpetuity. It is made available under aCC-BY 4.0 International license.

Figure 2 - Figure Supplement 1 Alterations in neuronal la-2 levels cause no obvious neuronal phenotypes, but can induce overgrowths

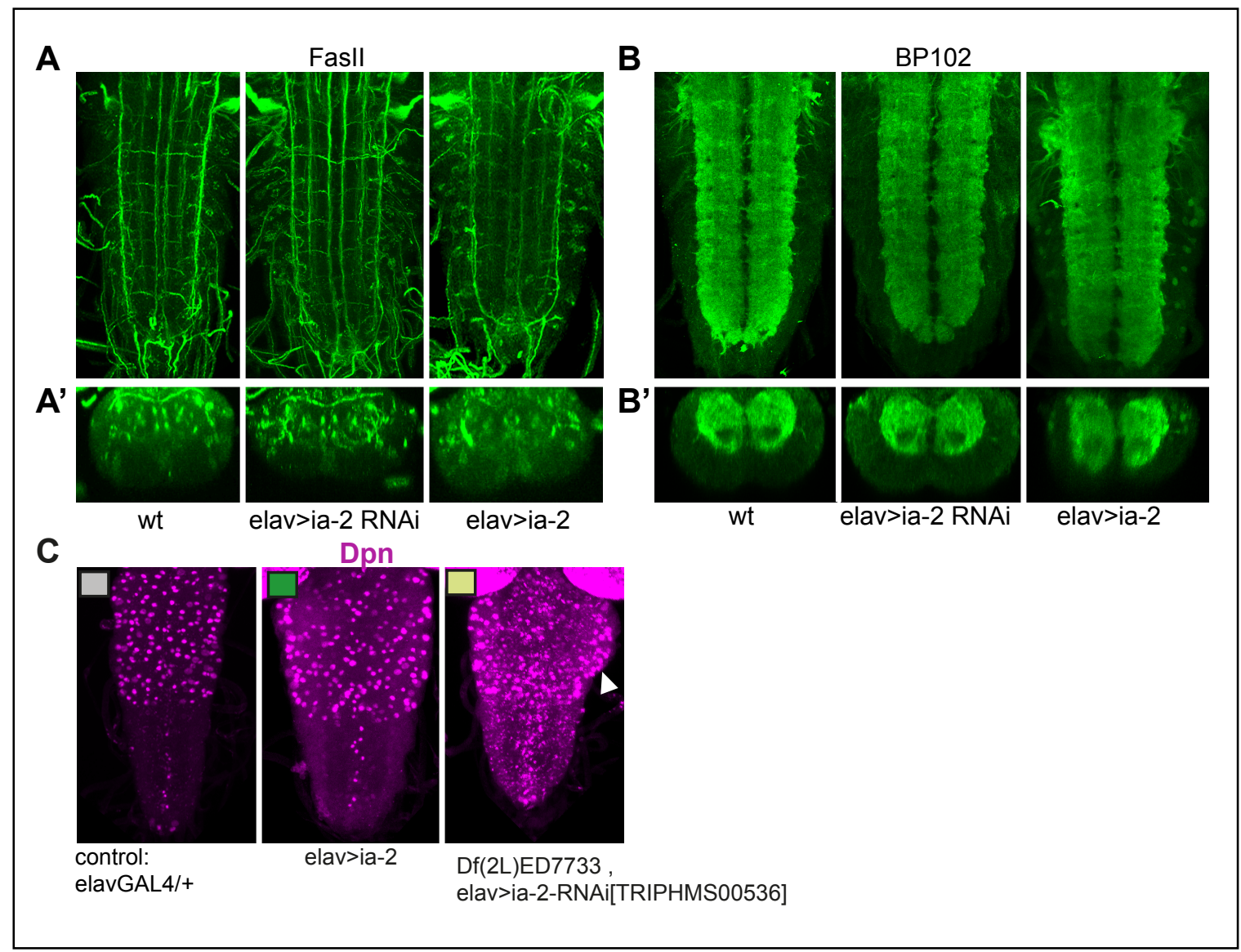


bioRxiv preprint doi: https://doi.org/10.1101/721498; this version posted June 22, 2020. The copyright holder for this preprint (which was

not certified by peer review) is the author/funder, who has granted bioRxiv a license to display the preprint in perpetuity. It is made

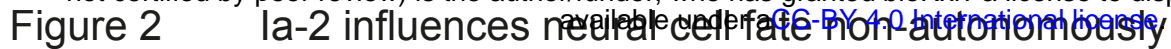

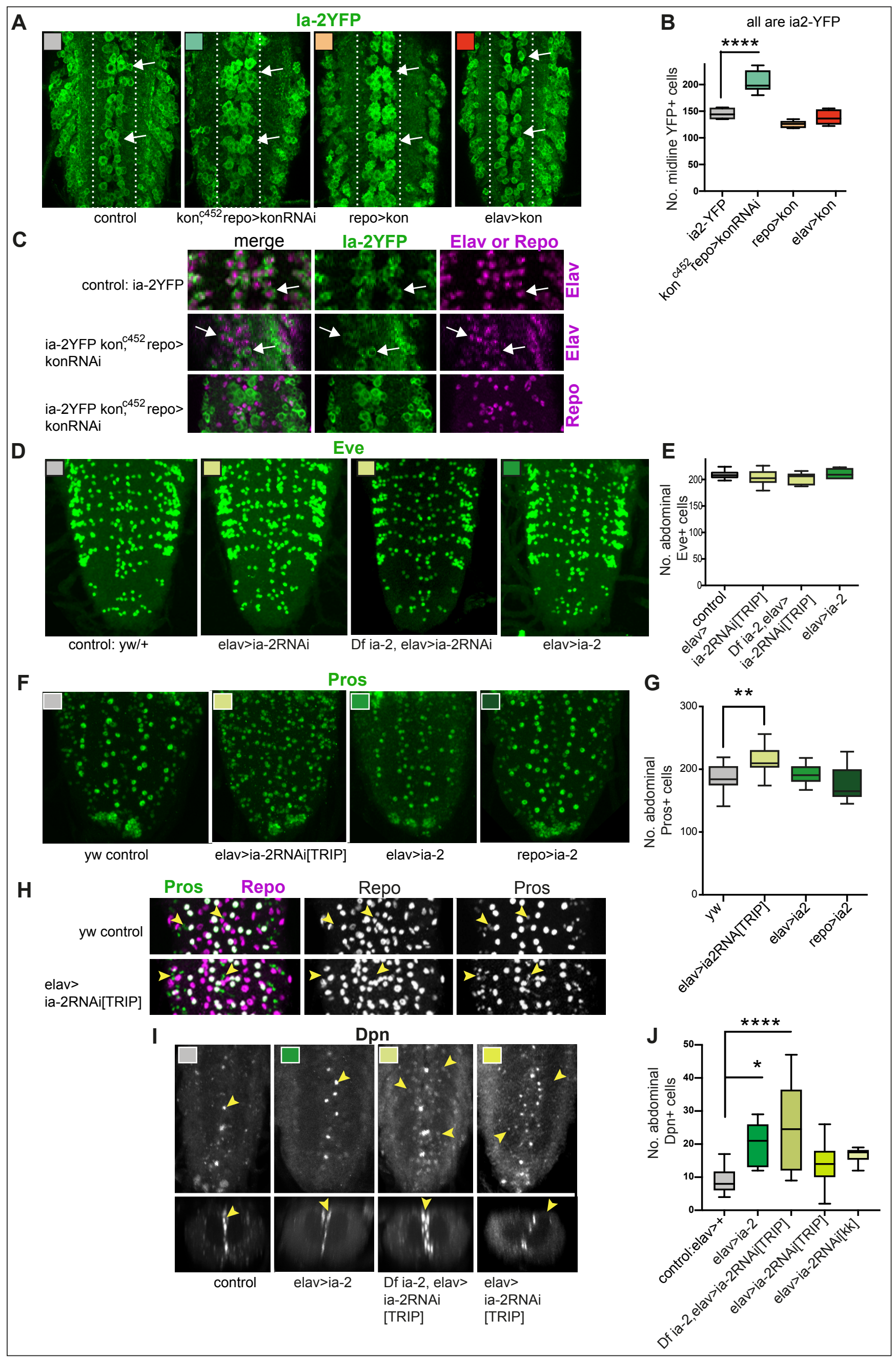


Figure 3 Injury induces ia-2 expression and ectopic Dpn+ cells

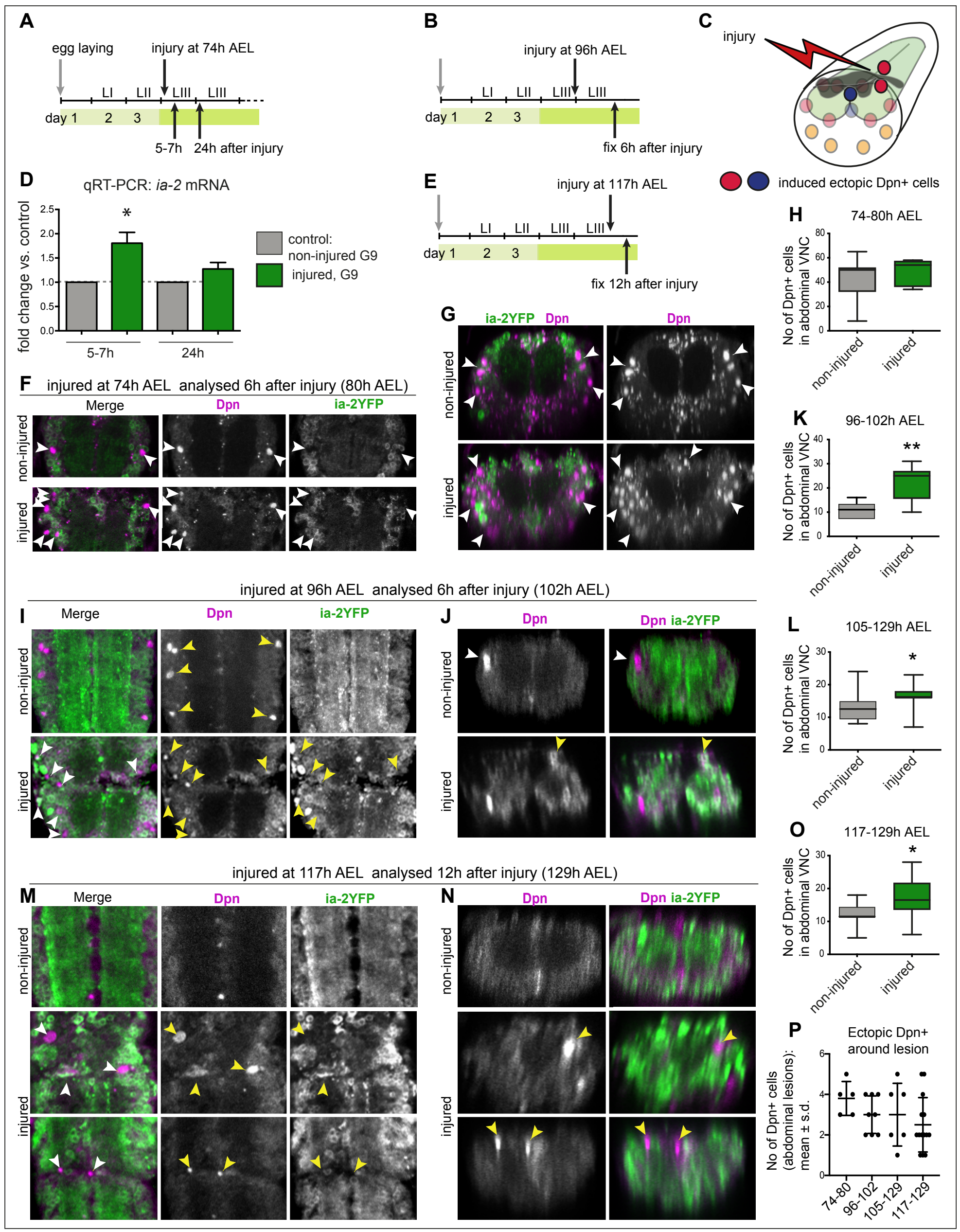


Figure 4 dilp-6 is expressed in neurons and cortex glia and received by neuropile glia

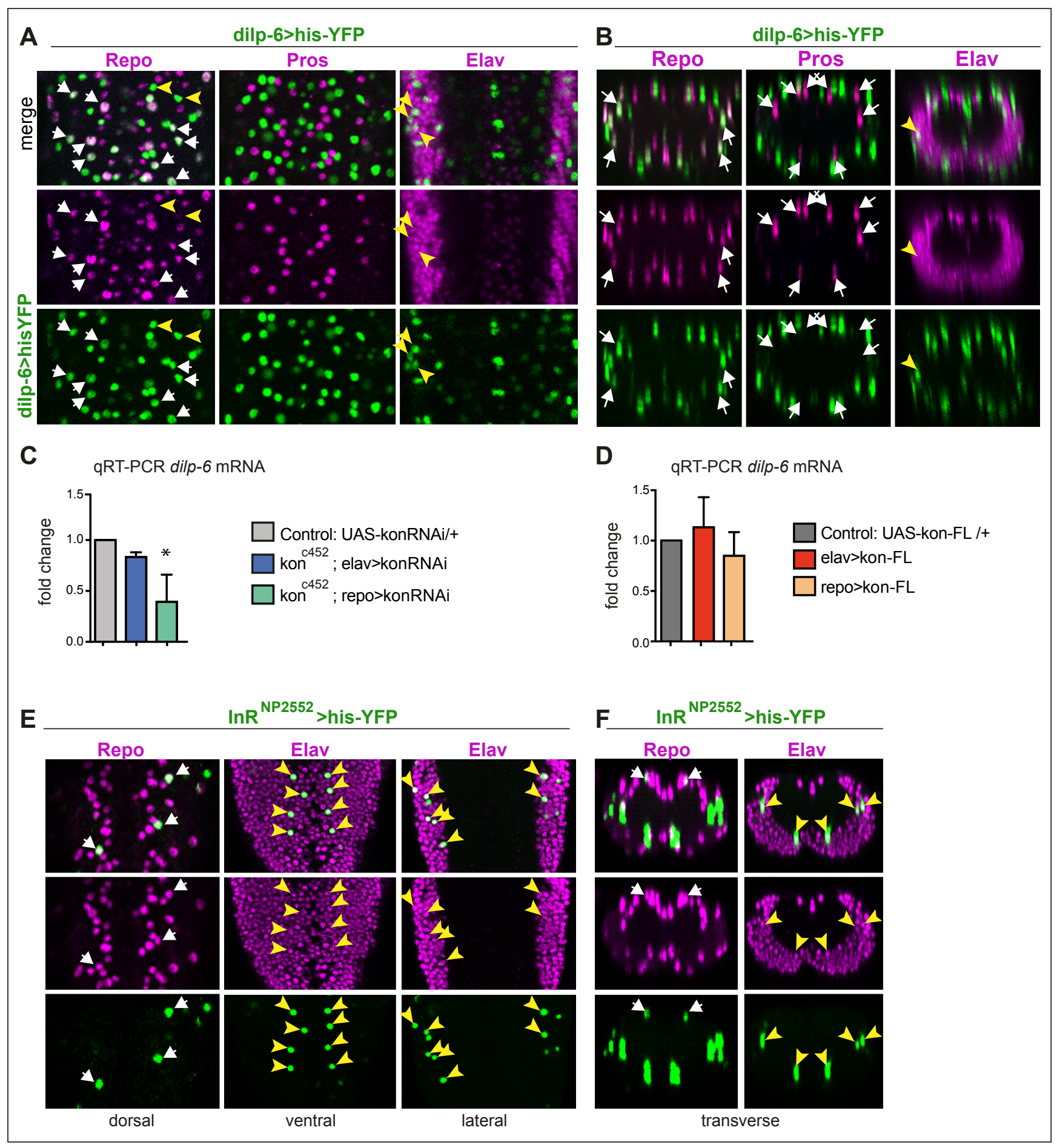


bioRxiv preprint doi: https://doi.org/10.1101/721498; this version posted June 22, 2020. The copyright holder for this preprint (which was not certified by peer review) is the author/funder, who has granted bioRxiv a license to display the preprint in perpetuity. It is made available under aCC-BY 4.0 International license.

Figure 5 - Figure Supplement 1

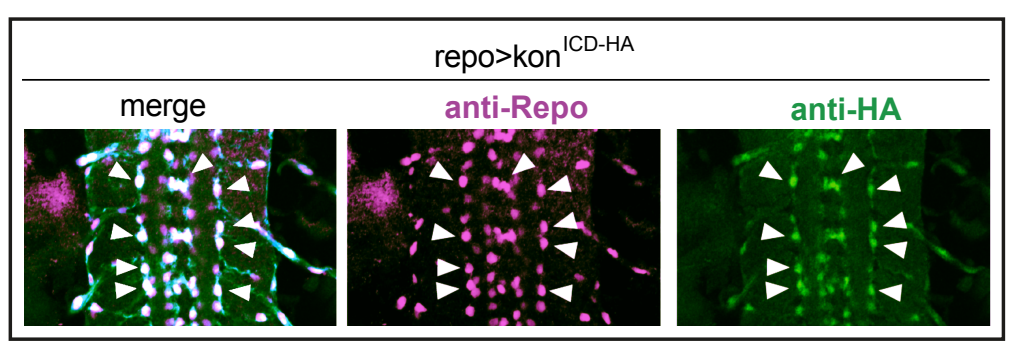


Figure $5 \quad$ la-2, Kon and Dilp-6 are linked though a neuron-glia communication loop.

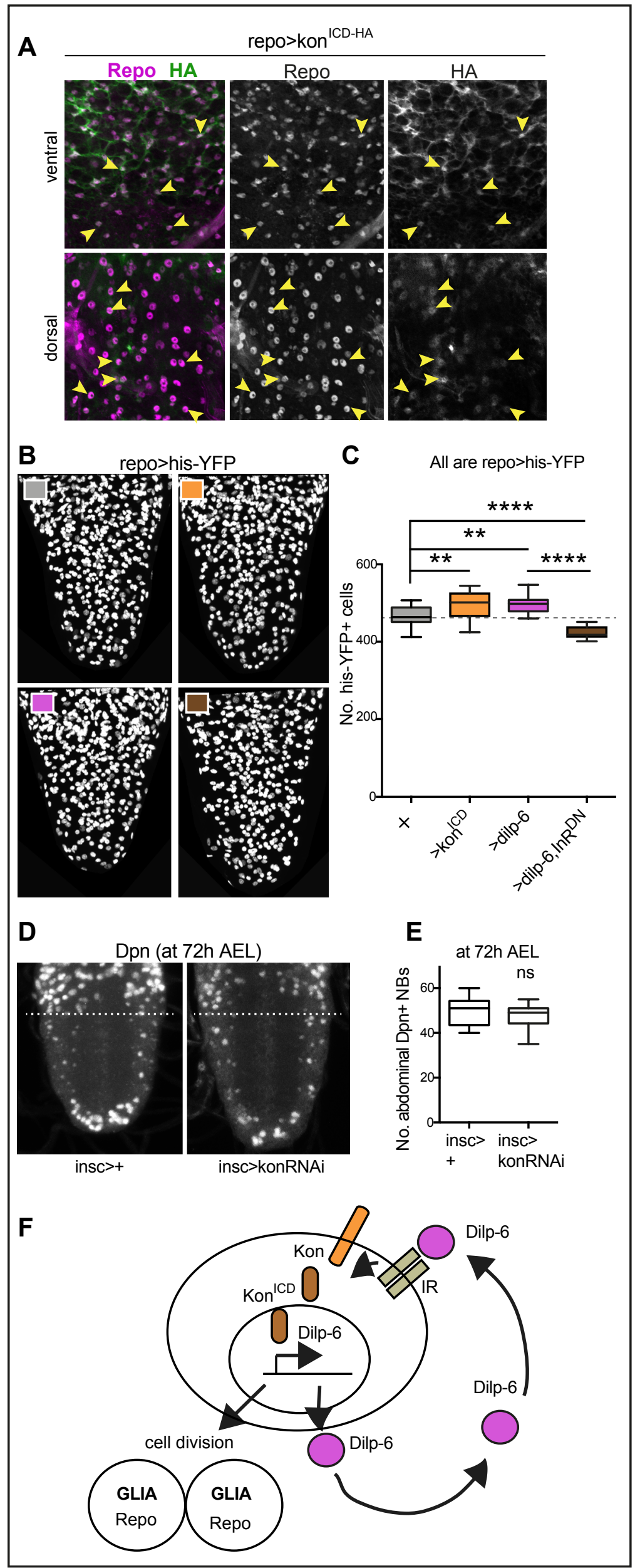


bioRxiv preprint doi: https://doi.org/10.1101/721498; this version posted June 22, 2020. The copyright holder for this preprint (which was

not certified by peer review) is the author/funder, who has granted bioRxiv a license to display the preprint in perpetuity. It is made available under aCC-BY 4.0 International license.

Figure $6 \quad$ la-2 and Dilp-6 induce ectopic neural stem cells from InR signaling in glia.

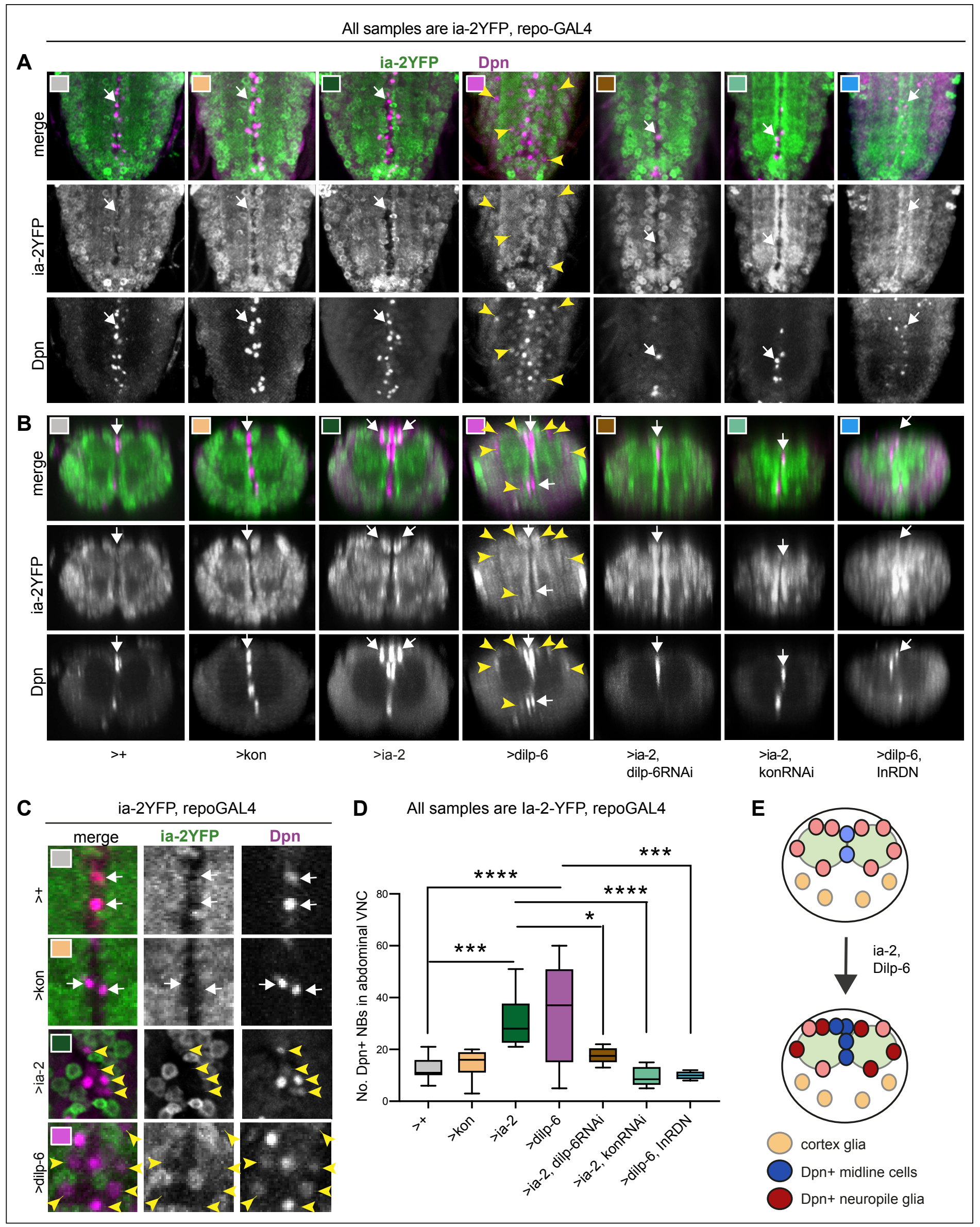




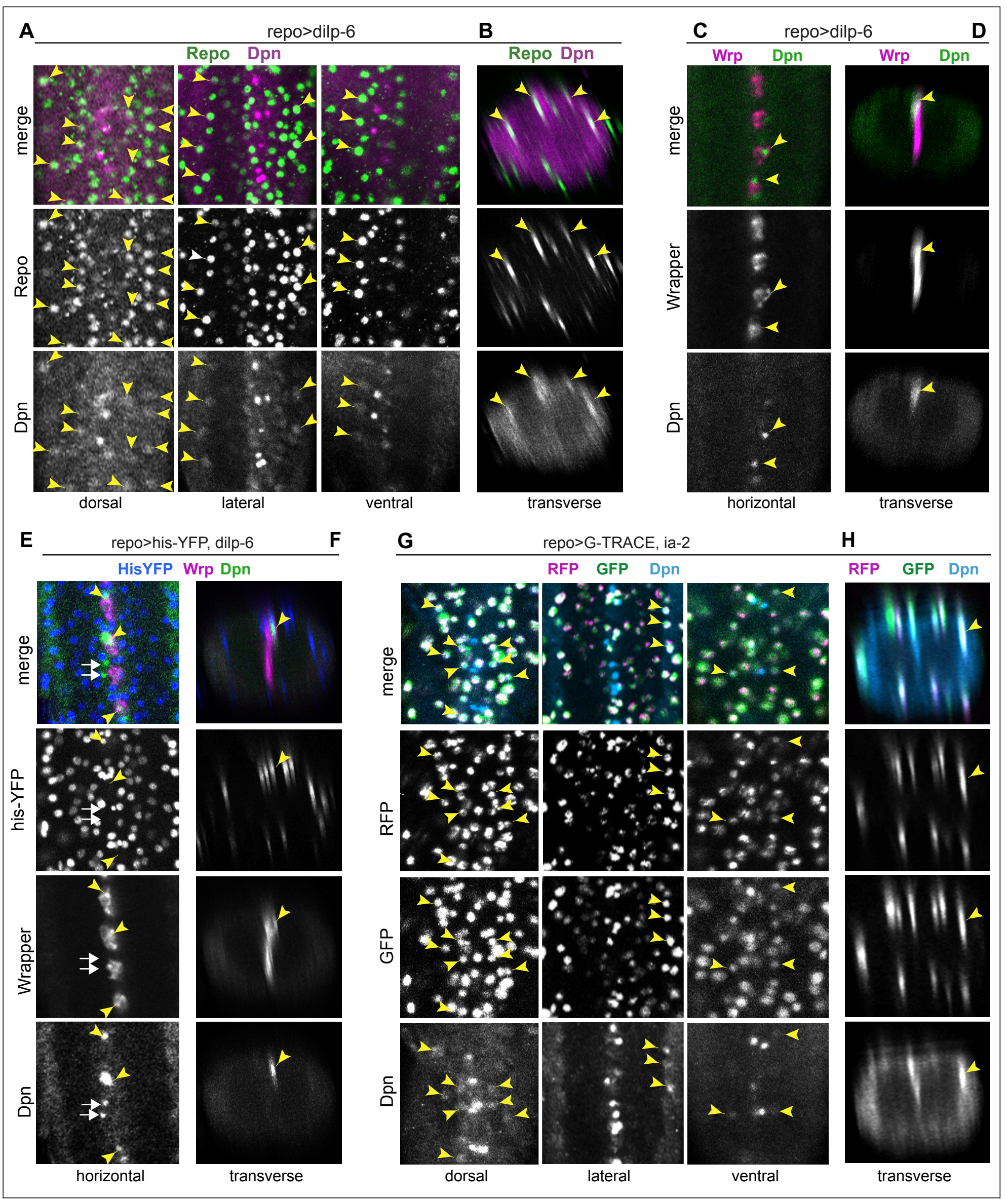


Figure 8 la-2 and Dilp-6 induced ectopic neural stem cells can divide

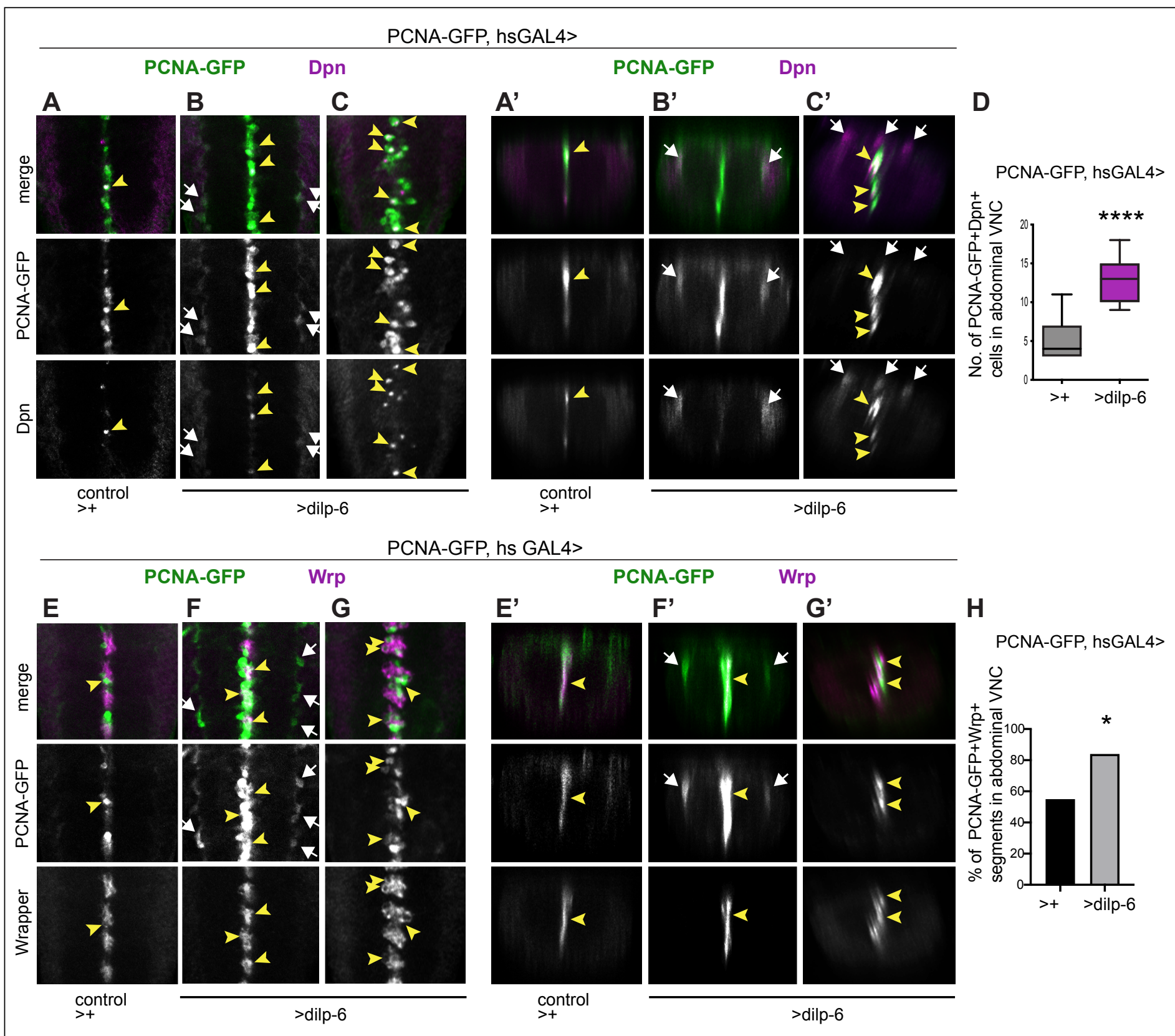

repo>his-YFP

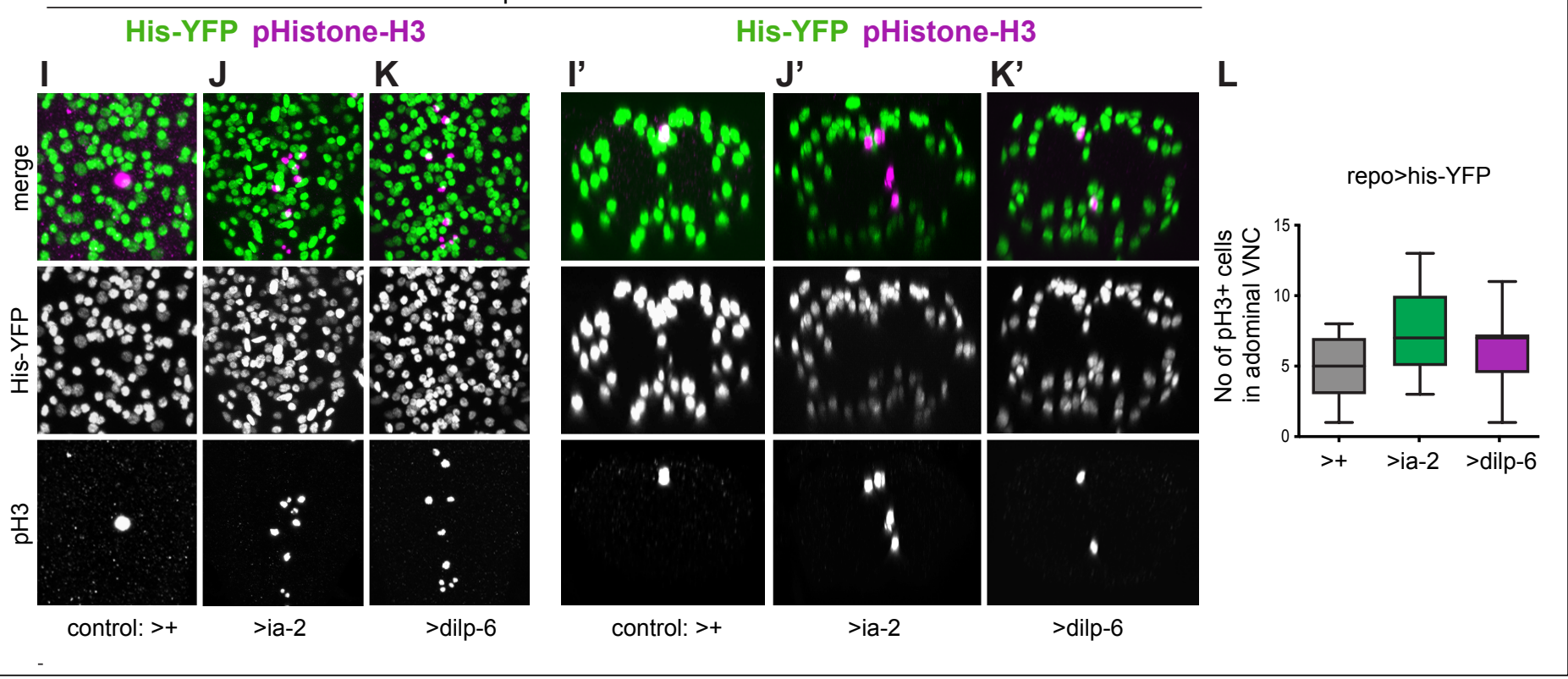


bioRxiv preprint doi: https://doi.org/10.1101/721498; this version posted June 22, 2020. The copyright holder for this preprint (which was

not certified by peer review) is the author/funder, who has granted bioRxiv a license to display the preprint in perpetuity. It is made available under aCC-BY 4.0 International license.

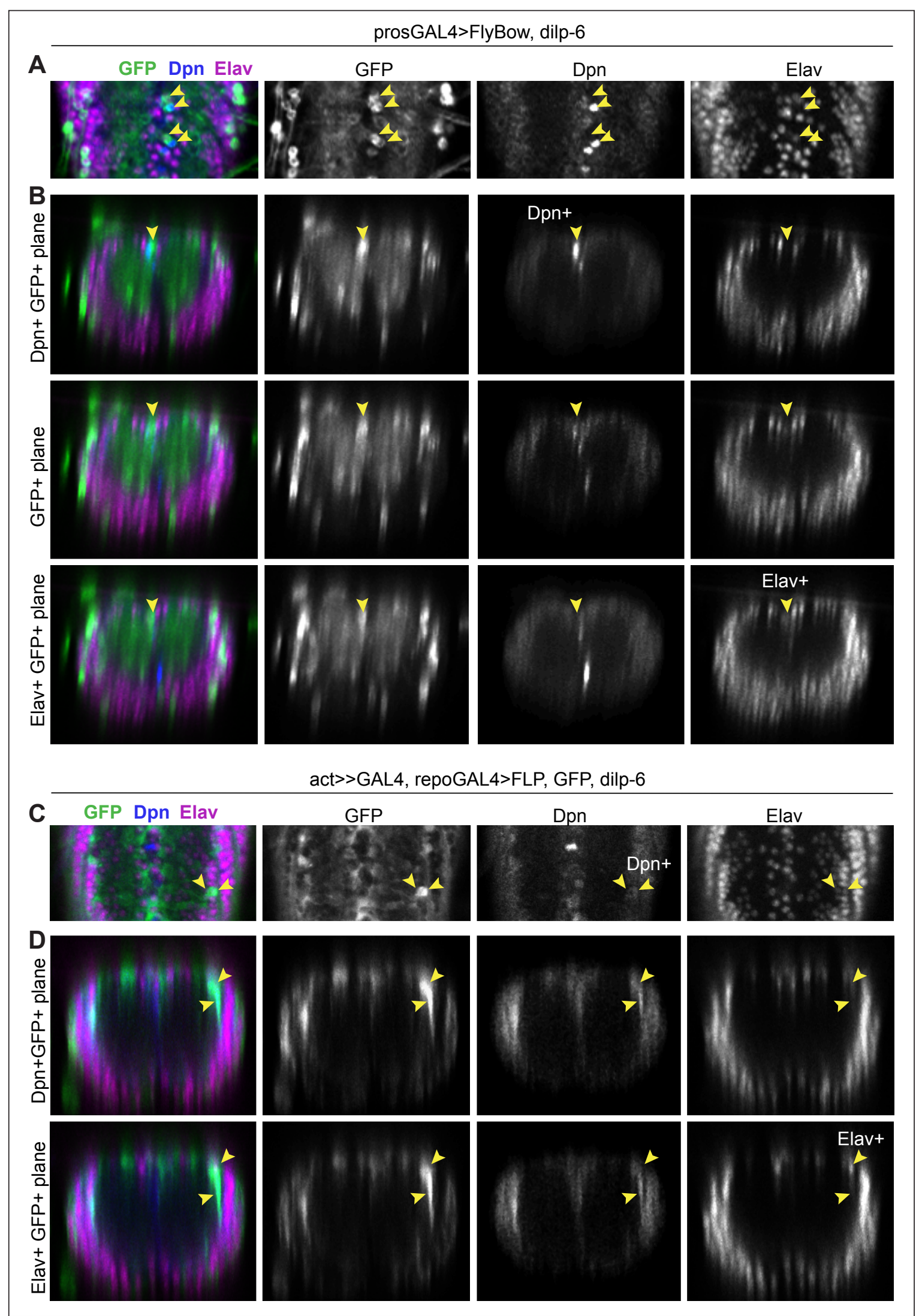


bioRxiv preprint doi: https://doi.org/10.1101/721498; this version posted June 22,2020 . The copyright holder for this preprint (which was

not certified by peer review) is the author/funder, who has granted bioRxiv a license to display the preprint in perpetuity. It is made available under aCC-BY 4.0 International license.

Figure $10 \quad$ la-2 and Dilp-6 drive a regenerative neurogenic response to CNS injury

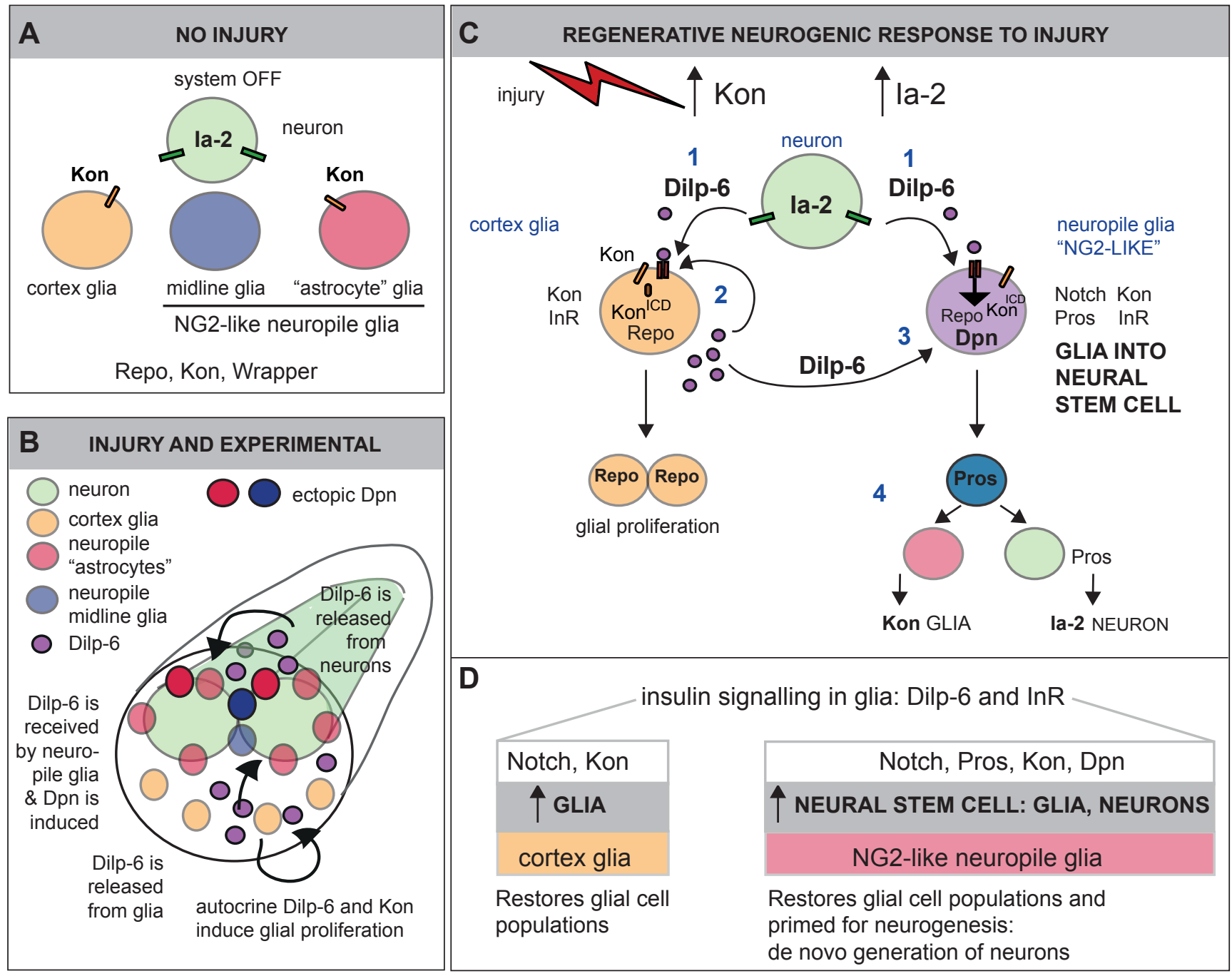

